WSRC-RP-92-793 REV 1

\title{
TECHNICAL BASES DWPF LATE WASHING FACILITY (U)
}

by D. L. Fish

Westinghouse Savannah River Company

WSRC-RP- -92-793-Rev. 1

Savannah River Site

Aiken, South Carolina 29808

Other Authors:

L. F. Landon

(WSRC)

This paper was prepared in cunnection with work done under Contract No. DE-AC09-89SR18035 with the U.S. Department of Energy. By acceptance of this paper, the publisher and/or recipient acknowledges the U. S. Government's right to retain a nonexclusive, royalty-free license in and to any copyright covering this paper, along with the right to reproduce and to authorize others to reproduce all or part of the copyrighted paper. 


\section{DISCLAIMER}

This report was prepared as an account of work sponsored by an agency of the United States Government. Neither the United States Government nor any agency thereof, nor any of their employees, makes any warranty, express or implied, or assumes any legal liability or responsibility for the accuracy, completeness, or usefulness of any information, apparatus, product, or process disclosed, or represents that its use would not infringe privately owned rights. Reference herein to any specific commercial product, process, or service by trade name, trademark, manufacturer, or otherwise does not necessarily constitute or imply its endorsement, recommendation, or favoring by the United States Government or any agency thereof. The views and opinions of authors expressed herein do not necessarily state or reflect those of the United States Government or any agency thereof.

This report has been reproduced directly from the best available copy.

Available to DOE and DOE contractors from the Office of Scientific and Technical Information, P. O. Box 62, Oak Ridge, TN 37831; prices available from (615) $576-8401$.

Available to the public from the National Technical Information Service, U. S. Department of Commerce, 5285 Port Royal Rd., Springfield, VA 22161. 
Keywords: DWPF, Precipitate Hydrolysis, Late Washing, ITP, Cross-Flow Filter

Retention Period: Permanent

CC: R. T. Begley, 773-A

L. M. Papouchado, 773-A

J. E. Lunn, 704-T

M. D. Boersma, 704-T

L.O. Dworjanyn, 779-2A

A. J. Garrett, 773-A

C. Nash, 786-5A

J. T. Carter, 704-1T

J. E. Marra, 773-A

M. J. Plodinec, 773-A

C. T. Randall, 704-T

W. E. Stevens, 773-43A

M. A. Baich, 704-T

A. S. Choi, 704-1T

R. E. Eibling, 704-T

R. A. Jacobs, 704-T

L. M. Lee, 704-T

J. C. Marek, 704-T

D. J. McCabe, 676-T

M. L. Mieyer, 676-1T

M. F. Morrissey, 676-4T

J. F. McGlynn, 773-A

D. D. Walker, 773-A

SRTC Records (4)

August 10, 1992

TO: E. W. HOLTZSCHEITER, 773-A

W. L. TAMOSAITIS, 773-A

FROM: D. L. FISH, 773-A - L. F. LANDON,Y704-T

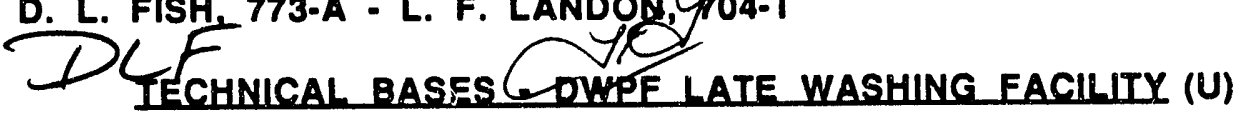

\section{INTBODUCTION}

The tetraphenylborate slurry produced during In-Tank Precipitation (ITP) operations in Tank $\mathbf{4 8}$ will be concentrated to nominally $10 \mathrm{wt} \%$ insoluble solids, washed and transferred to Tank 49 for storage. It is anticipated that the initial slumy produced will have accumulated in Tank 49 for at least two years before radioactive operation in DWPF commences $(6 / 94)$. Sodium nitrite additions will be required to prevent pitting corrosion of the carbon steel tanks. Current projections by Interim Waste Management indicate that the slurry temperature will be maintained between $55^{\circ} \mathrm{C}$ and $60^{\circ} \mathrm{C}$ (without additional cooling capacity). At $60^{\circ} \mathrm{C}$, the nitrite concentration in the slurry batched to the Late Wash Facility (LWF) will range between $0.13 \mathrm{M}$ and $0.14 \mathrm{M}$.

Laboratory-scale precipitate hydrolysis studies using tetraphenylborate slurry simulants irradiated to a dose equivalent to 2 years storage in Tank 49 (@24 Ci Cs-137/gal) have demonstrated that this level of nitrite and the radiolysis products produced during storage will (1) require a concentration of catalyst

Authorized Derivative Classifier

EU bhetpaluter 
during hydrolysis that will likely excees the copper solubility in glass and (2) necessitate the use of the reductant hydroxylamine nitrate (HAN) to reduce the production of organic tars. Although this flowsheet has been successfully demonstrater on a bench-scale and pilot-scale to meet hydrolysis technical constraints at nitrite concentrations in the feed slurry up to $0.20 \mathrm{M}$ (aqueous basis), the non-polar organics in the aqueous product (PHA) have been shown to steam strip in downstream melter feed preparation processes and accumulate in the vessel vent system. In addition, the HAN used during hydrolysis is the principal source of ammonium flow to the Chemical Process Cell which has been demonstrated to subsequently evolve as ammonia during melter feed processes and accumulate as ammonium nitrate (a known explosive) in the vessel vent system. These two conditions, unless mitigated, will compromise the safety and operability of the DWPF.

A task force recommended that the technical feasibility of a "Late Wash" facility be assessed [1]. In this facility, each batch of tetraphenylborate slurry from Tank 49 would be given a final wash to reduce the concentrations of nitrite and radiolysis products to acceptable levels. Laboratory-scale studies have demonstrated that if the nitrite content of the slurry fed to DWPF is reduced to $0.01 \mathrm{M}$ or less (and at least a $4 X$ reduction in concentration of the soluble species is attained). (1) the need for HAN during hydrolysis is eliminated (eliminating the production of ammonium ion during hydrolysis ), (2) hydrolysis may be done with a cateiyst concentration that will not exceed the copper solubility in glass and (3) the non-polar organic production during hydrolysis is significantly reduced. The first phase of an aggressive research and development program has been completed and all test results obtained to date support the technical feasibility of Late Washing.

Paralieling this research and development effort is an aggressive design study directed by DWPF to scope and cost retrofitting the Auxiliary Pump Pit (APP) to enable performing a final wash of each batch of precipitate slurry before it is transferred into the DWPF Salt Processing Cell (SPC). An initial technical bases for the Late Wash Facility was transmitted to DWPF on June 15, 1992. Research and development activities are continuing directed principally at optimization of the cross-flow filter decontamination methodology and pilot-scale validation of the recommended benzene stripping metodology.

\section{PROCESS DESCRIPTION}

\section{General}

The LWF must have the capability of producing a batch of washed slurry with a nitrite content equal to or less than $0.01 \mathrm{M}$ every 43 hours to meet the DWPF design basis attainment. Each batch received in the LWF will be treated with NaTPB to precipitate any soluble Cs-137, the insoluble solids concentration will be increased to $10 \mathrm{wt} \%$ and finally, the slurry will be washed to reduce the nitrite content to $0.01 \mathrm{M}$ or less.

Filtrate (spent wash) produced during the concentration/washing cycles will be accumulated in the APP's Recycle Pump Tank (RPT) and the Sludge Pump Tank (SPT). The benzene will then be stripped from the wash into the process vessel vent system followed by caustic addition. After analytically confirming that the Tank 22 receipt limits have been met (i.e. total radionuclide content $<0.60 \mathrm{Ci} / \mathrm{gal}, \mathrm{OH}$ - content $\geq 1.0 \mathrm{M}$ and the benzene concentration is less than $5 \mathrm{ppm}$ ), the spent wash will be transferred to Tank 22.

\section{Processing steps}

Step 1 A batch of precipitate slurry is iransferred from Tank 49 into the APP's Precipitate Pump Tank (PPT). The batch size would be that required to meet the DWPF design basis attainment. However, the batch size may be less if the nitrite content of the feed would produce an inhibited spent wash volume in excess of the working volume of the RPT and SPT.

Step 2 Sodium tetraphenyborate (NaTPB) is added to the PPT to reprecipitate any soluble cesium, potassium and ammonium in the slumy transferred from Tank 49. This step will achieve a minimum DF for Cs-137 of 150 (DF = the concentration of soluble cesium 
before reprecipitation divided by the concentration of soluble cesium after reprecipitation) and ensure the Tank 22 constraint ( $<0.61 \mathrm{Ci} / \mathrm{gal})$ is met.

Step 3 The slurry is filtered via the cross-flow filter to increase the total insoluble solids content to $10 \mathrm{wt} \%$.

Step 4 The slurry is recirculated through the cross-flow filter while wash water (containing $0.004 \mathrm{M} \mathrm{NaTPB}$ ) is added at a rate equivalent to the cross-flow filter permeate rate until the nitrite content of the aqueous fraction of the washed slurry is reduced to $0.01 \mathrm{M}$ or less. The permeate (spent wash) is accumulated in the RPT and the SPT.

Step 5 Following drainage of any washed precipitate in the cross-flow filter and associated piping to the PPT, the washed precipitate slurry is transferred to the Precipitate Reactor Feed Tank (PRFT) in the SPC after confirmation that the nitrite content of the aqueous fraction is $0.01 \mathrm{M}$ or less.

Step 6 As the permeate from the washing operation accumulates in the RPT and the SPT, it is continuously stripped into the vessel vent system by a combination of nitrogen sparging and spraying into the vapor space to reduce the soluble benzene content of the spent wash to $5 \mathrm{ppm}$ or less.

Step 7 Sufficient $\mathbf{5 0}$ wt\% sodium hydroxide is added to the spent wash to adjust the hydroxide content to $1.0 \mathrm{M}$ or greater.

Step 8 Following confirmation that the spent wash meets radionuclide, benzene and hydroxide limits, the spent wash is transferred to Tank 22.

Figure 1 is a process flow diagram of the Late Wash Process.

\section{MATERIAL BALANCE}

A late wash material balance has been prepared based on ITP operations being carried out in Tank 48 at a temperature of $60^{\circ} \mathrm{C}$. Assuming two years storage in Tank 49 , the nitrite content in the aqueous fraction of a slurry batch transferred into the LWF will range from $0.13 \mathrm{M}$ to $0.14 \mathrm{M}$. The calculational bases and a complete material balance across the Late Wash Facility are located in Appendix A.

Table I lists batch sizes for selected process streams based on the reference material balance in Appendix A. As shown in Tabie l, the inhibited spent wash ( 9000 gallons) is at $95 \%$ of the combined capacity afforded by the RPT and the SPT. This is due in large part to the 650 gallons operating heel in the PPT. Without this heel, the quantity of inhibited spent wash produced per cycle (at a nitrite concentration in the precipitate slurry batched to the PPT of $0.135 \mathrm{M}$ ) is about 8,000 gallons, or $85 \%$ of the combined capacity of the RPT and SPT. Consequently, the maximum allowable nitrite concentration in the precipitate slurry batched to the LWF is about 0.15 .

\section{TECHNICAL BASES}

\section{General}

It is assumed that the LWF will use a cross-flow fitter identical in filter surface area to that to be used in In-tank Precipitation. This fitter has $230 \mathrm{ft}^{2}$ of filter surface.

- The late wash cycle is 43 hours (based on DWPF design basis attainment).

- The portion of the late wash cycle to execute washing is limited to a maximum of 20 hours.

The wash cycle period ( 20 hours) is based on attaining an average crossflow filter permeate flux of $0.032 \mathrm{gal} / \mathrm{min}-\mathrm{ft}^{2}$ over a wash cycle assuming a wash water requirement ( $\left.\sim 8750 \mathrm{gal}\right)$ that would produced 9400 gallons of inhibited spent wash - the maximum combined capacity of the RPT and the SPT. 
- Maximum available spent wash storage capacity in the APP is 9400 gallons.

- Technical constraints for spent wash transfer to Tank 22:

- Benzene must be equal to or less than $5 \mathrm{ppm}$

- Radionuclide content must be less than $0.61 \mathrm{Ci} / \mathrm{gal}$

- Hydroxide content must be equal to or greater than $1.0 \mathrm{M}$

- At least a $4 X$ dilution of the soluble species in the slurry batched to the Late Wash Facility must be attained in the late wash cycle to mitigate the impact of soluble organic species (produced by radiolysis during storage in Tank 49) on the effectiveness of the copper catalyst during precipitate hydrolysis.

- The precipitate slurry recirculation pump and the transfer pump in the PPT must be of the low shear type.

- Water used for (1) precipitate washing, (2) filter flushing and (3) makeup of cold chemicals must be pretreated to ensure that no insoluble solids are present (or produced) that could plug the cross-flow fitter.

- Water to be used for washing must be adjusted with NaTPB solution (0.55M NaTPB $-0.10 \mathrm{M}$ $\mathrm{NaOH}$ ) to a target NaTPB concentration of $0.004 \mathrm{M}$ to $0.0045 \mathrm{M}$.

\section{Characterlstics of Tetraphenylborate Slurry Batched to the Late Wash Facillity}

This section describes the physical and chemical properties of typical irradiated, washed tetraphenylborate precipitate simulant slurry to be batched to the LWF. However, it should be recognized the the chemical makeup of this slurry can vary significantly.

\section{Chemical}

\begin{tabular}{|c|c|c|c|}
\hline Insolubles & $w_{t} \%(d x y)^{a}$ & solubles & $W_{t} \%(d x y)^{b}$ \\
\hline $\begin{array}{l}\text { KTPB } \\
\text { CsTPB } \\
\text { NH4TPB } \\
\text { Hg(C6H5)2 } \\
\text { NaTi2O5H } \\
\text { BaSO4 } \\
(\mathrm{C} 6 \mathrm{H} 5) 2 \\
(\mathrm{C} 6 \mathrm{H} 5) 2 \mathrm{C} 6 \mathrm{H} 4 \\
\mathrm{C} 6 \mathrm{H} 5 \mathrm{~B}(\mathrm{OH}) 2\end{array}$ & $\begin{array}{l}85.5 \\
1.26 \\
4.88 \\
2.03 \\
2.22 \\
0.50 \\
2.29 \\
0.28 \\
0.98\end{array}$ & $\begin{array}{l}\mathrm{Na} 2 \mathrm{C} 2 \mathrm{O} 4 \\
\mathrm{Na} 2 \mathrm{CO} 3 \\
\mathrm{Na} 2 \mathrm{SO} 4 \\
\mathrm{NaAl}(\mathrm{OH}) 4 \\
\mathrm{C} 6 \mathrm{H} 5 \mathrm{OH} \\
\mathrm{C} 6 \mathrm{H} 6 \\
\mathrm{CsOH} \\
\mathrm{KOH} \\
\mathrm{NH} 4 \mathrm{OH} \\
\mathrm{Na2B4O} 7 \\
\mathrm{NaNO} 2 \\
\mathrm{NaNO} 3 \\
\mathrm{NaOH} \\
\mathrm{Na2CrO4} 4 \\
\mathrm{Na3PO} 4 \\
\mathrm{NaCl} \\
\mathrm{NaF} \\
\mathrm{Na} 2 \mathrm{SiO} 3\end{array}$ & $\begin{array}{c}5.11 \\
42.9 \\
0.66 \\
1.19 \\
7.45 \\
0.99 \\
0.19 \\
5.95 \\
1.84 \\
6.01 \\
26.8 \\
0.55 \\
0.063 \\
0.018 \\
0.047 \\
0.044 \\
0.021 \\
0.016\end{array}$ \\
\hline & wt\% (wet) & $\begin{array}{l}\mathrm{pH} \\
\text { Density }\end{array}$ & $\begin{array}{l}\sim 10 \\
63.6 \mathrm{lbs} / \mathrm{ft}^{3}\end{array}$ \\
\hline $\begin{array}{l}\text { Insoluble Solids } \\
\text { Soluble Solids } \\
\text { Water }\end{array}$ & $\begin{array}{c}9.12 \\
3.07 \\
87.8\end{array}$ & $\begin{array}{l}a-I n \\
b-S\end{array}$ & $\begin{array}{l}\text { Solids Fraction Only } \\
\text { olids Fraction Only }\end{array}$ \\
\hline
\end{tabular}

Density $\quad 64.0 \quad \mathrm{lbs} / \mathrm{tt}^{3}$ 


\section{Physical}

The following data are based on a slurry that has been irradiated to a dose equivalent to 2-years storage in Tank 49 (assuming $24 \mathrm{Ci} / \mathrm{gal} \mathrm{Cs-137)} \mathrm{and} \mathrm{contains} \mathrm{a} \mathrm{total} \mathrm{insoluble} \mathrm{solids} \mathrm{content} \mathrm{of}$ $\sim 10 w t \%$.
- Consistency
- Yield Stress
3.0
$\mathrm{cp}$
dynes/cm2

Consistency and yield stress for a slurry irradiated to a dose less than that equivalent to 2 years storage in Tank 49 is shown in Figures 2 and 3.

\section{Process Cycles}

\section{Batch Transfer from Tank 49 to PPI}

A batch of washed precipitate slurry will be transferred from Tank 49 to the PPT at least every 43 hours to meet the DWPF design basis attainment.

\section{Beprecipltation}

During storage in Tank 49, a fraction of the the Cs/K/NH4TPB becomes soluble due to radiolysis. It is conservatively projected that $6.5 \%$ per year of the tetraphenylborate solids solubilize. NaTPB is added to reprecipitate the Cs/K/NH4 to ensure the Cs-137 content of the spent wash meets the Cs-137 limit for transfer to Tank 22 [2].

- Precipitant - NaTPB

- Solution Composition (identical to the NaTPB solution to be used in ITP)

- NaTPB $\quad 0.55 \mathrm{M}$

- $\mathrm{NaOH} \quad 0.10 \mathrm{M}$

- Density - $63.6 \mathrm{lbs} / \mathrm{tt}^{3}$

- Storage Considerations

- Freezing Point $\left(-5^{\circ} \mathrm{C}\right)$

- Flammability

Freeze protection recommended

NaTPB contains benzene. Tank should be blanketed with nitrogen

- Capacity

- Transfer Rate Nominal addition - 504 gallons

- Benzene Generation No technical basis for a controlled rate of addition to the PPT

NaTPB thermally decomposes. Recommend storage temperature not to exceed $40^{\circ} \mathrm{C}$

- NaTPB Requirement

\section{Calculational Basis: see Appendix B}

The required quantity of NaTPB is based on the stoichiometric quantity needed to precipitate the soluble potassium, cesium and ammonium plus that required to adjust the aqueous fraction to $0.004 \mathrm{M}$ NaTPB. The composition of the batch of precipitate slurry used to calculated the NaTPB requirement will be the last analyses of the slurry in storage in Tank 49 corrected for the elapsed period between the time the sample was obtained from Tank 49 and the time that reprecipitation is planned in the PPT. Sampling the PPT after each batch of slurry is received from Tank 49 is received is not required.

- Mix Period After Ad:ition - 30 minutes 
Surface Actlve Agent Addition (post NaTPB addition)

It is not anticipated that a surface active agent will have to be added to mitigate foaming and enhance cross-flow filter performance. Research and development are continuing in this area. However, for purposes of developing a cost estimate for the proposed Late Wash Facility, it is recommended that facilities be included in the scope-ut-work capable of delivering a surface active agent to the PPT.

Although the preferred surface active agent has not been determined, for the purpose of sizing the surfactant tank, it is assumed that the surfactant Surfynol 104E would be used (limited crossflow -filter tests have been performed using Surfynol 104E):

- Specific Gravity $-0.999 @ 25^{\circ} \mathrm{C}$

- Concentration of Active Component - 50 wt\%

- Surface Active Agent Batch Size

Calculational Basis: See Appendix B

Based on the material balance in Appendix $A$, about 4 gallons of Surtynol 104E would be added to the PPT after reprecipitation to attain $500 \mathrm{ppm}$ (by weight) of the active component in the Surfynol 104E solution.

- Surface Active Agent Hold Tank Capacity

Recommend the LWF scope-of-work include a $\mathbf{5 0}$ gallon surfactant tank servicing the PPT.

- Mix Period After Addition Prior to Next Process Step - 15 minutes

\section{Concentration}

Following reprecipitation, the slurry is filtered to raise the concentration of insoluble solids 10.0 $w t \%$. The filtrate is accumulated in one of the spent wash hold tanks. Concentrating the slurry prior to washing offers two distinct advantages. First, the quantity of wash water required to reduce the nitrite content to $0.01 \mathrm{M}$ is reduced and secondly, the batch size to the Salt Processing Cell (SPC) is reduced.

- Target Insoluble Solids Concentration - 10 wt\%

Calculational Basis: see Appendix B

No additional analyses other than that of the batch transferred from Tank 49 will be required.

Note: The sample schedule will call for a sample to be taken post concentration and analyzed for nitrite content of the aqueous fraction and iotal insoluble solids. This is not a process control sample but will be used to validate the initial calculation of the wash water requirement. If a correction to the wash water requirement is required, the wash cycle period allows adequate time to make such an adjustment.

- Physical Characteristic of Concentrated Product Slurry (@11.0 wt\% insoluble solids)

Consistency - $4 \mathrm{cp}$

Yield Stress - $<10$ dynes/cm2

- Cross-Flow Filter Process Operating Parameters

See "Cross-Flow Filter Parameters" in subsequent section. 


\section{Washing}

During this step, wash water is added to the PPT at a rate equivalent to the cross-flow filter permeate rate. Agitation is maintained throughout the wash cycle to ensure the PPT behaves as a weel mixed, continuously stirred tank. Loss of agitation should be accompanied by the immediate shutdown of the slurry recirculation pump and the wash water delivery system. The wash water addition rate can be controlled off the level of the slurry in the PPT. The permeate from the crossflow fitter is accumulated in the spent wash hold tanks (RPT and SPT).

\section{Wash Water Specifications}

All water used for washing, cross-flow filter flushing, makeup of cleaning solutions, makeup of trim chemicals and layup of the cross-flow filter must be pretreated to ensure there are no insoluble solids introduced into the system (or subsequently produced) that could plug the cross-flow filter. See Section - "Water Treatment" for pretreatment options.

In addition, the chemical composition of the water used for washing must be as follows:

- NaTPB Concentration $-0.0035 \mathrm{M}$ to $0.0045 \mathrm{M}$

- NaOH Concentration $-0.001 \mathrm{M}$ to $0.010 \mathrm{M}$

The NaTPB content of the wash water is required to prevent a portion of the CSTPB from becoming soluble during the washing cycle. Failure to maintain an excess of NaTPB in the precipitate slurry throughout the wash cycle could result in the Cs-137 concentration in the spent wash water potentially exceeding the Tank 22 limit.

\section{Wash Volume}

That volume of wash water required to reduce the nitrite concentration of the aqueous fraction of the slurry to $0.01 \mathrm{M}$ or $\mathrm{Es5}$. See Appendix B for the algorithm to calculate the wash water requirement. The initial e'stimate of the wash water requirement will require no additional off-line analyses. However, when the analytical results of the post-concentration sample are received (NO2- and total insoluble solids), the initial estimate of the wash water requirement will be checked and adjusted as required.

Nominal wash water requirement - 7300 gallons

\section{Wash Water Addition Rate}

The wash water delivery system must be capable of metering the wash water into the PPT at a rate equivalent to the permeate rate (i.e. at a rate that maintains the slurry level in the PPT constant). It is recommended that the wash water delivery system be capable of matching a cross-flow filter permeate flux ranging from $0.010 \mathrm{gal} / \mathrm{min}-\mathrm{ft}^{2}$ to $0.16 \mathrm{gal} / \mathrm{min}-\mathrm{ft}^{2}$.

\section{Cross-Flow Filter Operating Parameters (applicable to washing/reconcentration cycles)}

Typical cross-flow filter process operating parameters are indirated below. A subsequent section addresses the cross-flow filter design bases.

- $\quad$ Slumy velocity in cross-flow filter tubes

- Transmembrane pressure

- Slurry temperature

- Backpulse frequency

- Backpulse pressure

- Backpulse duration
$6 \mathrm{ft} / \mathrm{sec}$ (nominal)

15 psig to 25 psig

$20^{\circ} \mathrm{C}-30^{\circ} \mathrm{C}$

every $5 \mathrm{~min}$

125 psig $\pm 10 \%$ (nitrogen)

$1.0 \cdot 2.0$ seconds 
Backpulsing involves forcing permeate radially back through the filter pores to dislodge accumulated solids from the filter (while the slurry continues to circulate through the filter tubes).

\section{Post Washina/Cross-Flow Filter Layup}

Following the wash cycle, the cross-flow filter system is drained of residual washed precipitate into the PPT. The washed slurry is then ready for transfer to DWPF pending confirmation that the nitrite content of the aqueous fraction of the washed precipitate slurry is $0.01 \mathrm{M}$ or less.

If the cross-flow filter permeate flux at the conclusion of the wash cycle is greater than 0.045 $\mathrm{gal} / \mathrm{min}-\mathrm{ft}^{2}$ or the required transmembrane pressure to sustain the permeate flux is less than 25 psig, a cleaning cycle is not required and the cross-flow filter need only inventoried with water until the next concentration cycle. If the permeate flux or transmembrane pressure at the end of the wash cycle do not meet these constraints, a cleaning cycle should be executed (see section "Recovering Cross-Flow Filter Flux")

\section{Benzene Stripoing}

The benzene content of the spent wash must be reduced to $5 \mathrm{ppm}$ or less to permit transfer to Tank 22. This will be accomplished by a combination of sparging the spent wash (@50 ${ }^{\circ} \mathrm{C}$ ) with nitrogen and recirculating the spent wash via spray nozzles into the vessel vapor space of the PRT and SPT. Laboratory experiments and modeling studies indicate the benzene content of the spent wash can be reduced to $5 \mathrm{ppm}$ in less than 20 hours [3]. It is important that the nitrogen sparging and spraying be initiated as soon as fittrate from the concentration cycle and the spent wash begins to be received in a spent wash hold tanks.

Design Bases:

Sparging

- Srarge Fluid

- Sparging Rate

- Bubole Size

- Spent Wash Temperature

Recirculation

- Recirculation Rate

- Number of Spray Nozzles

- Spent Wash Temperature

- Spray Droplet Size
Nitrogen

1.24 scfm/tt ${ }^{2}$ of wash surface

$2 \mathrm{~mm}$

$50^{\circ} \mathrm{C}$

Figure 4 depicts the projected benzene profile in the RPT and the SPT during the wash cycle.

During the benzene sparging cycle, foam will be produced. Using cross-flow filter permeate produced during washing of irradiated precipitate, studies were conducted to determine foam height as a function of wash temperature, degre of agitation and sparge rate. At a sparge flux $1.33 \mathrm{scfm} / \mathrm{tt2}$, (design basis $=1.24 \mathrm{scfm} / \mathrm{ft} 2$ ), $\varsigma_{2}, 10$ time did the foam height exceed 5 inches. ir. $\theta$ foam is unstable and rapidly subsides upon stopping sparging and agitation [3].

\section{Inhlbltor Adjustment of Spent Wesh}

Transfers into Tank 22 must contain a hydroxide concentration of at least 1.CM.

- Inhibitor - $50 \mathrm{wt} \% \mathrm{NaOH}$

- Caustic Requirement 


\section{Calculational Bases: see Appendix B}

- Nominal $\mathrm{NaOH}$ Requirement - $\mathbf{5 0 0}$ gallon

\section{CROSS-FLOW FILTER DESIGN BASES}

The cross-flow filter system is to be capable of meeting the following requirements:

- Minimum Filter Surface

- Filter Pore Size

- Material of Consruction

- Slurry/Cleaning Solution Velocity in Cross-Fow Filter Tubes

- Transmembrane pressure

- Slurry Temperature

- Backpulse Frequency

- Backpulse Pressure

- Backpulse Duration

\author{
$230 \mathrm{ft}^{2}$ \\ 0.5 micron (nominal) \\ $316 \mathrm{~L} \mathrm{SS}$ \\ 4 to $8 \mathrm{ft} / \mathrm{sec}$ \\ 0 psig to 60 psig \\ $<40^{\circ} \mathrm{C}$ a \\ every 5 - $30 \mathrm{~min}$ \\ 90 psig to 125 psig (nitrogen) \\ $0.5 \mathrm{sec}$ to $10 \mathrm{sec}$
}

a - The system to limit the temperature of the slurry entering the cross-flow filter to a maximum of $40^{\circ} \mathrm{C}$ must accommodate the maximum temperature the slurry transferred from Tank 49. Interim Waste is currently developing what the maximum temperature a batch of washed slurry will be that is transferred to the LWF. Until this design paranieter is available, $60^{\circ} \mathrm{C}$ should be assumed.

\section{CROSS-FLOW FILTER PEREORMANCE}

Essentially all the cross-flow filter performance data with irradiated tetraphenylborate slurries have been been developed in a bench-scale unit consisting of a single 0.5 micron, $3 / 8$-inch ID $\times 167 / 8$-inch long filter tube, and a three gallon recirculating tank [4]. A diaphragm pump was used to re-circulate the slurry at constant solids concentration by returning the permeate to the recirculating tank. The inlet pressure and the tube flow (linear velocity) was adjusted to gather flux measurements at various pressures and flows. Table 11 in an excerpt from Reference 4 summarizing cross-flow filter performance using irradiated feed.

Filter performance decay is summarized in Figure 5. The decay is slight, both for fresh and reprecipitated slurry and indicates that filter cleaning may not be needed after each late wash cycle.

Based on the data obtained from bencin-scale tests, a permeate flux of $0.032 \mathrm{gal} / \mathrm{min}$-ft ${ }^{2}$ (required flux to aifect washing in the LWF within 20 huurs - assuming the maximum wash water requirement) appears easily attainable.

\section{BECOVERING CROSS-FLOW FILTER FLUX}

During cross-flow filtration the permeate flow drops off rapidly as a filter cake accumulates on the surface of the filter tubes. Frequent backpulsing (reverse permeate flow) is used to lift the filter cake and resiore flow. However, as the filtration continues, the pores plug with fines and the permeate flux (at a given transmembrane pressure) gradually falls off to an unacceptable rate, or the transmembrane pressure required to maintain an acceptable permeate flux gets too high, necessitating cleaning. Although the frequency of the need to clean the filter has not been determined, provisions to clean after each late wash cycle should be provided.

The most effective cleaning technique demonstrated to date is high flow ( $6 \mathrm{ft} / \mathrm{sec})$ axial recirculation of 4 $w t \%$ oxalic acid through the fitter tubes followed by low velocity flushing with $4 \mathrm{wt} \% \mathrm{NaOH}$ solution. It is recommended that the cleaning solutions be reused to minimize waste volume. The oxalic acid solution should be replaced when the $\mathrm{pH}$ exceeds 2 . The sodium hydroxide solution should be replaced when the $\mathrm{pH}$ falls below 13. The oxalic acid solution should also be replaced if the radiation level exceeds 0.25 mrem/hr at the outside of the shielding wall. Recent tests indicate that spent cleaning solutions will have to be replaced every 5 to 6 cleaning cycles. 
The LWF must be engineered to prevent cleaning solutions and rinses/flushes from being discharged into the PPT or spent wash hold tanks (RPT and SPT)

Facilities and systems are to be provided to meet the following design criteria and recommended crossflow filter cleaning strategy:

\section{cleaning Solution Vessel Requilements}

Qxalic Acid Cleaning Tank ( $\left.4 \mathrm{wt} \% \mathrm{H}_{2} \mathrm{C} 2 \mathrm{O} 4\right)$

This tank must at least accomodate the equivalent cross-flow fitter and associated piping system inventory ( 250 gallon) plus that additional volume which will ensure the oxalic acid recirculation pump will not nu dry when circulating oxalic acid through the filter at $8 \mathrm{ft} / \mathrm{sec}$. The larger the capacity of this tank the less frequent spent cleaning solution will have to be transferred to Tank 48. Material of construction - 304L SS. Sampler required.

Caustic Cleaning Iank ( $4 \mathrm{wt} \% \mathrm{NaOH})$

The caustic will be used to flush the filter system. Material of construction - 304L SS. Sampler required.

\section{Spent Flush Tank}

This tank will be used to accumulate the cleaning solution inventory in the cross-flow filter system that is flushed following each cleaning solution recirculation cycle. Recommended minimum capacity - 3000 gallons. Sampler required. Material of construction - 304-L SS.

\section{Blologlcal Shlelding Requilrement}

The cell designed to accomodate the cleaning solution storage tanks must have sufficient biological shielding to reduce the radiation level to $0.25 \mathrm{mr} / \mathrm{hr}$ based on a cieaning solution inventory of 6000 gallons containing $6.0 \mathrm{Ci}$ of $\mathrm{Cs}-137 / \mathrm{L}$. A preliminary assessment of tho biological shieiding requirement is described in Reference 5 . This report was transmitted to DWPF under tranmittal letter WSRC-RP-92-902TL on July 17, 1992.

\section{Cold Feed Service Requirements}

To Oxalic Acid Cleaning Iank: 4 wt\% oxalic acid

$50 \mathrm{wt} \% \mathrm{NaOH}^{\mathrm{a}}$

Treated water

To Caustic Cleaning Tank: $\quad 4 \mathrm{wt} \% \mathrm{NaOH}$

Treated water

Io Spent Flush Tank:

$50 w \% \mathrm{NaOH}^{a}$

Treated water

Io Wash Water Tank

$0.55 \mathrm{M}$ NaTPB, $0.10 \mathrm{M} \mathrm{NaOH}$ solution

Io Recycle Pump Tank $\quad 50 \mathrm{wt} \% \mathrm{NaOH}^{\mathrm{a}}$

Ie Sludge Pump Iank $\quad 50 \mathrm{wt} \% \mathrm{NaOH}^{\mathrm{a}}$

a- the $50 \mathrm{wt} \% \mathrm{NaOH}$ storage tank will require fieeze protection 


\section{Pump Requirements}

- The Oxalic Acid Cleaning Tank's reci lation pump must be capable of recirculating oxalic acid solution through the cross-flow filter at $6-8 \mathrm{ft} / \mathrm{sec}$ with the permeate being returned to the source of the cleaning solution. The recircluation pump in the Caustic Cleaning Tank need only be be capable of flushing the system at a low recirculation rate $(0.5$ to $1.0 \mathrm{ft} / \mathrm{sec})$. Each tank must have a transfer pump to transfer spent cleaning solution to Tank 48.

- The Spent Flush Tank must have the capability to transfer spent flush solutions to Tank $\mathbf{4 8 .}$

\section{cleaning Sequence}

Step 1 Fill cross-flow filter with water. Pulse 10 times, each pulse duration $1-2 \mathrm{sec}$. Drain to PPT.

Step 2 Repeat Step 1

Step 3 De-inventory shell side to PPT (via backpulsing or draining)

Step 5 Recirculate $4 \mathrm{wt} \%$ oxalic acid solution for $f, 0$ minutes at $6-8 \mathrm{ft} / \mathrm{sec}$ while backpulsing for $1.0-2.0$ seconds every 5 minutes

Step 6 Flush system with 250 gallon of water to the Spent FlushTank. Drain system (including shell side) to Spent Flush Tank

Step 7 Recirculate $4 \mathrm{wt} \%$ sodium hydroxide solution for 60 minutes at 0.5 to $1.0 \mathrm{tt} / \mathrm{sec}$ while back.julsing for $1.0-2.0$ seconds eveny 5 minules

Step 8 Flush system with $\mathbf{2 5 0}$ gallons of water to the Spent Flush Tank to Spent Wash Tank.

\section{PROCESS WATER TREATMENT}

Process water will be used in the preparation of cleaning solutions, cross-flow filter flushes, cross-flow filter layup and precipitate slumy wash water. During the cold run testing of the ITP cross-flow fitter, the filter plugged with process water (well water). The pluggage has been tentatively attributed to the colloidal iron and silica content of the process water (well water). Treatment by fittration with the appropriate filter porosity will remove these colloidal particles. However, the hydroxide content of the precipitate slurry could precipitate soluble cations in the process water such as iron which could subsequently plug the cross-flow fitter. Pretreatment is required. Two options are recommenden for assessment:

\section{Ention 1 - Air Oxidation/Filtration}

- Adjust $\mathrm{pH}$ of process water to $10-11$

- Sparge the water with air

- Contact Time - 15 minutes

- Total air sparge requirement - 3 tank volumes

- Filter through a 0.2 micron filter

\section{Eption 2 - Filtration/lon Exchange}

This option uses a deionizer (mixed bed) to remove the soluble cations and anions. The process water flow to the deionizer must be filtered through a 0.2 micron filter. The effluent from the deionizer must be adjusted to a pH between 10 and 11 with $\mathrm{NaOH}$.

\section{EXTENDED OUTAGE}

If the cross-flow filter system is going to be down for an extended period ( $>2$ days), the fitter cleaning sequence is to be performed. 


\section{EMERGENCY SHUTDOWN}

If during the late wash slurry concentration cycle or the wash cycle services are lost (e.g. power failure), the capability to drain the slurry from the cross-flow filter tubes to the PPT and layup the filter tubes with water are required.

\section{ELAMMABILITY CONTROL.}

\section{Late Wash Facillity}

The projected benzene emissions from washed tetraphenylborate precipitate in the PPT re "led in Design Change Form (DCF - 20676) treing a.pproved for appropriate modifications to address ine flammability control strategy in both the APF' and the Low Point Pump Pit. During washing of the precipitate in the APP'S PPT, benzene will accompany the spent wash that will be accumulated in the RPT and the SPT. A similar flammability control strategy (MOC control) should be implemented to prevent a flammable atmosphere occurring in the RPT and SPT vessel vent systems.

The vapor effluents from the pump tanks will be combined with the air sweep of the pur it and filtered before discharge to the atmosphere. The vessel vent header is to be maintainu, ate by air dilution [i.e. the benzene concentration is maintained below the Lower Flammability Limit (LFL) for benzene in air - 1.3 vol\%]. The APP pump pit process vessel vent sysiem is presently designed to maintain the benzene concentration below $25 \%$ of the LFL assuming an instantaneous benzene emission rate of $25 \mathrm{krh}$. Eacii batch of precipitate processed in the LWF will contain about $7 \mathrm{lbs}$ of benzene which will be stripped to the atmosphere. In addition, some adc tional benzent is expected to be generated during oxalic acid cleaning of the filter, by radiolysis and by thermal decomposition of NaTPB. The present APP air dilution design basis should be adequate to handle the exxpected benzene emissions from the IWF.

The required alarms and interlocks specified in DCF-20676 should be extended to the APP'S RPT and SPT and adhered to upon implementation of the Late Wash Facility.

The APP is currently scoped to have an oxygen analyzer to riwnitor the oxygen content of the vapor exiting the PPT. Reliance on an oxygen analyzer common to all three vessel vent flows doesn't assure the oxygen content in the vapor exiting each tank is below the MOC. The capability to determine the oxygen content in the vapor space of each pump tank must be provided. One option is to provide on-line oxygen monitoring of the vapor exiting each pump tank.

\section{Tank 22}

The current OSR requires the capability to respond to a ventilation outage within 7 days. The time that the benzene concentration in the Tank 22 vapor space would reach the LFL in the event of a ventilation outage assuming the spent wash from the Late Wash Facility is transferred to Tank 22 has been reassesed. Rased on the calculational bases itemized below, it will take 240 days to reach the LFL for benzene in aif (1.3 vol\%).

Calculational Basses.(Late Wash - average case)

- Temperature of Tank 22 Contents $-55^{\circ} \mathrm{C}$

- Sodium lon Concentration - $2.2 \mathrm{M}$

- Volume in Tank $22-455,000$ gallons

- Cs-137 Concentration - $0.004 \mathrm{Cil}$

- Benzene Concentration in Stripper Bottoms - $1 \mathrm{mg} / \mathrm{L}$

Even in an extreme case (see calculational bases below), the time to reach the LFL in event of a ventilation outage is 14 days. This is still longer than the time allowed in the current OSR.

Consequently, there are no changes required to the ITP OSR or the ITP Process Requirements. 


\section{SAVANNAH RIVER TECHNOLOGY CENTER}

Calculational Bases_(extreme case)

- Temperature of Tank 22 Contents $-70^{\circ} \mathrm{C}$

- Sodium Ion Concentration - 2.2 M

- Volume in Tank $22-1,000,000$ gallons

- Cs-137 Concentration - 0.16 CilL (Tank 22 limit)

- Benzene Concentration in Stripper Bottoms - $5 \mathrm{mg} / \mathrm{L}$

The time to reach the LFL in the Tank 22 vapor space is most sensitive to the temperature of the tank contents and the volume. The Cs-137 concentration and ITP benzene stripper efficiency have very little effect.

\section{PERMITTING BEQUIREMENTS}

The pump pits are currently included in the DWPF permitted omiasions. This permit assumes that essentially all of the benzene in solution in the precipitate slurry transferred from Tank 49 is released from one or the other of the pump pits (the APP or the Low Point Pump Pit). With Late Washing, essentially all the benzene in the precipitate slurny will be sparged to the atmosphere. Some additional benzene will be generated due to oxalic acid cleaning of the cross-flow filter, by radiolysis and thermal decomposition of the NaTPB. The total projected emissions from the pump pits in the DWPF permit should not change significantly.

Elimination for the need for the reductant (HAN) during precipitate hydrolysis in the SPC will change the flammability control strategy during precipitate hydrolysis. Less inert flow will be required and consequently benzene emissions from the SPC to the atmosphere are projected to be reduced from about 30 tons/yr to about 18 tons/yr (depending on the amount of NOx generated during precipitate hydrolysis - data not yet acquired).

These process changes will require minor modifications to the DWPF air permit and possibly to the DWPF waste water permit (due to changes in the SPC operation).

The radionuclide (and NaTPB) content of the spent wash transferred to Tank 22 from the Late Wash Facility will increase benzene emissions from Tank 22. The ITP air quality permit and waste water permit would likely require some modification.

TANK 22 SPENT WASH ACCEPTANCE LIMITS [6]

$\begin{array}{ll}\circ \text { Free Hydroxide } & \\ \circ \text { Benzene } & \leq 1.0 \mathrm{M} \\ \circ \text { Radionuclide } & \leq 5 \mathrm{ppm} \\ \circ \text { Temperature } & \leq 0.61 \mathrm{Ci} \text { gal } \\ 0 & \leq 70^{\circ} \mathrm{C}\end{array}$

\section{SAMPLE AND ANALYTICAL SCHEDULE}

Feed Batch (these data will be available from Tank 49 sampling results)

Nitrite (aqueous fraction)

Total Insoluble Solids

KTPB

CsTPB

NH4TPB

$\mathrm{Hg}(\mathrm{C} 6 \mathrm{H} 5) 2$

Cesium (soluble)

Potassium (soluble)

Ammonium (soluble)

Soluble Benzene

$\mathrm{pH}$
Typical Concentration

ppm

$w t \%$

$w t \%$

$w t \%$

$w t \%$

$w t \%$

ppm

ppm

ppm

ppm
$6,000-6450$

$9.0-9.2$

7.8

0.12

0.45

0.18

50

1300

300

$300-350$

$10-11$ 
Preclpltate Slurry - Post Concentration

Nitrite (aqueous fraction)

Total Insoluble Solids

ppm $\quad 5000-6000$

Note: These are not process control analyses in the sense sinat the subsequent processing step (washing) must wait until the analytical results are avaiiable. The results will be used to validate the previously determined wash water requirement and if necessary, appropriately adjust the wash water requirement before the end of the wash cycle.

Washed Preclpltate Slurry* (at end of wash cycle in PPT)

Nitrite (aqueous fraction)

$\mathrm{ppm} \quad \leq 460$

Spent Wash (post benzene stripping - post inhibitor adjustment)

Total radionuclide concentration

Benzene

Free Hydroxide

$\begin{array}{lc}\text { Cigal } & 0.006-0.61 \\ \mathrm{ppm} & 1.0-5.0 \\ \mathrm{M} & 1.0-1.3\end{array}$

Wash Waier

NaTPB $\quad \mathrm{Na}+$

TPB-

ppm

$92-104$

$\mathrm{pH}$

0.004

$10 \cdot 11$

\section{Cold Feeds}

NaTPB

$$
\begin{aligned}
& \mathrm{Na}+ \\
& \text { TPB- } \\
& \text { OH- }
\end{aligned}
$$

$\mathrm{Cu}++$

$M$
$M$

ppm

$w t \%$

$w t \%$

$\mathrm{NaOH}$

Spent Oxalle Acld cleaning Solution

$\mathrm{H}+$

Total H+ Equiv

$\leq 0.88$

Spent Caustic Cleaning Solution

Hydroxide

Total Base Equir

$0.25-1.0$

\section{Elush Tank Solution}

Hydroxide

Acidity

Oxalate
$\mathrm{OH}-$

$\mathrm{H}+$

$\mathrm{C2O}=$ 


\section{CORROSION}

Cyclic potentiodynamic polarization scans were performed on Type 304L stainless steel specimens immersed in an irradiated simulant of the spent wash (filtrate) solution to be produced in the proposed Late Wash Facility. Tests were run at temperatures of 50,80 and $90^{\circ} \mathrm{C}$. The results indicate that $304 \mathrm{~L}$ stainless steel is immune to localized corrosion in this application. The polarization scans showed that the passive film remained intact, and the post-scan microscopic examination of the specimens showed no pitting [7].

\section{MONITORING/DATA ACOUISITION REOUIREMENTS}

\section{Vessels}

Precipitate Pump Tank

- Temperature

o Level

- Foam Level

Note: A pneumatic bubbler terminating in vapor space above the maximum projected liquid level has proven effective in detecting foaming in the Precipitate Reactor located in the 1/5-scale Precipitate Hydrolysis Experimental Facility (PHEF)
- Specific Gravity
- Agitator Speed
- N2 Purge Rate
- Vapor Space Pressure

\section{Becycle Pump Tank}

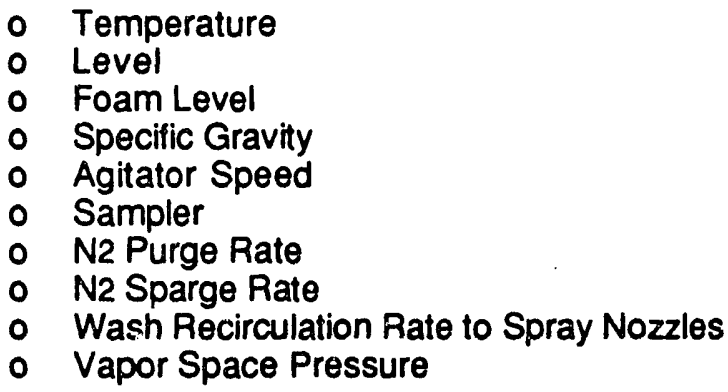

\section{Sludae Pumo Tank}

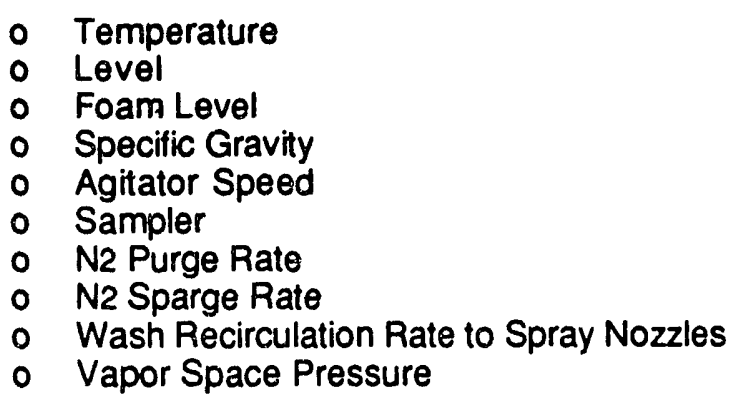

\section{Suffactant Tank}
- Level
- Specific Gravity 
Cross-Flow Filter Cleaning Solution Tanks

- Level

- Specific Gravity

- Agitator Speed

- Temperature

- Radiation at Cell Wall Exterior

Backpulse Tank

- Level

- Vapor Space Pressure

Wash Water Storage Tank

- Level

$\mathrm{NaOH}$ Tank

- Level

- Specitic Gravity

NaTPB Solution

- Level

- Specific Gravity

\section{Processing Operatlons}

\section{Concentration/Wash Cycles}

- Slumy Flow to Cross-Flow Filter (calculated linear velocity display)

- Temperature of Slurry Entering Cross-Flow Filter

- Transmembiane Pressure

- Cross-Flow Filter Permeate Rate

- Wash Water Addition Rate (this flow should be level controlled by the level in the PPT)

- Flow Differential Between Wash Water Rate and Permeate Rate

- Backpulse N2 Pressure

- Backpulse Frequency

- Backpulse Duration

- Cs-137 Concentration in Cross-Flow Filter Permeate Flow

- Nitrite Concentration in Cross-Flow Filter Permeate Flow

- $\triangle$ P Across Slurry Inlet/Outlet of Cross-Flow Filter Tubes

- PPT Agitator Speed

\section{Benzene.Bemoval from Soent Wash}

- Nitrogen Sparge Rate

- Spent Wash Recirculation Rate to Spray Nozzles

- Inlet pressure to Spray Nozzles

\section{Elammability Control}

- Nitrogen Flow to Vessel Vapor Space of PPT, RPT and SPT

- Oxygen Concentration in Vapor Exiting PPT. RIPT and SPT

- Benzene Concentration in Process Vessel Vent Header

- Pressure in NaTPB Storage Tank Vapor Space 


\section{INTERLOCK REQUIREMENTS}

In addition to normal process control interlock responses (e.g. stopping transfers into a tank at a HIGH-

HIGH liquid level, flammability control, etc.), the fellowing special interlock and alarm actions are required:

- Upon loss of agitation in the PPT during the wash cycle, flow of wash water into the PPT must be stopped and the PPT recirculation pump must be shutdown.

- The nitrogen sparge to the RPT and the SPT and agitation should be stopped upon detection of foam.

- LOW recirculation flow (<10 spm) to the RPT and SPT spray nozzles to be alarmed

- LOW slurry flow to the cross-flow filter ( $<4 \mathrm{ft} / \mathrm{sec}$ ) to be alarmed

- LOW-LOW slurry flow to the cross-flow filter $(<3 \mathrm{ft} / \mathrm{sec})$ to shutdown PPT recirculation pump and all transfers into the PPT

- HIGH slurry flow to the cross-flow filter ( $>8 \mathrm{ft} / \mathrm{sec}$ ) to be alarmed.

- LOW transmembrane pressure (<10 psig) to be alarmed.

- HIGH transmemibrane pressure (25 psig) to be alarmed.

- HIGH-HIGH transmembrane pressure $(>40 \mathrm{psig})$ to shutdown PPT recirculation pump and all transfers into the PPT.

- Flow differential ( $>0.5 \mathrm{gpm}$ ) between wash water flow to the PPT and the permeate flow to be alarmed.

- HIGH pressure drop (>5.0 psig) across the cross-flow filter tubes to be alarmed.

- If process heat exchangers are used to control the temperature of the slumy entering the crossflow filter, pressure drop between the shell side and the process side must be maintained greater than 15 psig. If the differential falls below 15 psig, an alarm should be activated.

\section{SPECIAL ORV-LINE MONITORING}

If technically feasible, the following on-line monitoring systems are recommended:

- System to monitor the nitrite concentration in cross-flow filter permeate flow.

- System to measure the gamma activity (calibrated in Cs-137 equivalents) in spent wash water flow to the RPT and the SPT.

- System to monitor the benzene concentration inthe spent wash water being circulated to the spray nozzles in the RPT and SPT.

- If process heat exchangers are employed, system to monitor the gamma activity in the recirculation cooling water.

\section{SERVICES}

- Nitroger : RPT, SPT and PPT Vapor Space (flammability control))

- Nitrogen to RP T and SPT Spargers

- Nitrogen to NaTPB Storage Tank (flammability control)

- NaTPB to PPT

- NaTPB to Wash Water Tank

- Surfactant to PPT

- 125 psig Nitrogen to Cross-Flow Filter Permeate Backpulse Tank

- Wash Water to PPT (insoluble solids particle size $<0.2$ micron)

- $4.0 \mathrm{wt} \%$ Oxalic Acid to Oxalic Acid Cleaning Tank

- $4.0 \mathrm{wt} \% \mathrm{NaOH}$ to Caustic Cleaning Tank

- Flush Water to Cross-Flow Filter

- N2 flow to PPT, RPT and SPT Liquid Level Pneumatic Bubbler Tubes

- Nitrogen Flow to PPT, RPT and SPT Foam Detectors (if this type of foam detection is employed)

- Flush Water to Foam Detectors

- $50 \mathrm{wt} \% \mathrm{NaOH}$ to Oxalic Acid Cleaning Tank

- $50 \mathrm{wt} \% \mathrm{NaOH}$ to Spent Flush Tank

- $50 \mathrm{wt} \% \mathrm{NaOH}$ to SPT and RPT 


\section{REFERENCES}

1. J. C. Marek, "DWPF Report of Task Force on Options to Mitigate the Effect of Nitrite on DWPF Operations (U)", WSRC-TR-92-67, March 1992.

2. D. D. Walker, "Precipitation Kinetics in Late Washing", SRT-LWP-92-073, May 18, 1992.

3. L. F. Landon, "Benzene Stripping - Late Wash Facility - Status Report", SRTC-PTD-92-036, July 31, 1992.

4. L. O. Dworjanyn and M1. F. Morrissey, "Initial Technical Basis for the Use of a Spare ITP Filter in DWPF Late Washing (U)", WSRC-RP-92-766, June 5, 1992.

5. S. A. Epperson, "New Spent Wash Tank and New Wash Cleaning Tank Preliminary Shielding Analysis", ESH-HPT-92-0246, June 17, 1992.

6. L. V. Ehrke, "ITP Acceptance Criteria for Late Wash Water to Tank 22", WER-WMH-920180, April 22, 1992.

7. P. E. Zapp, "Corrosion Evaluation for 304L Stainless Steel in the Spent Wash Water from the Proposed Late Washing Facility (U)", SRT-MTS-92-3016, May 8, 1992. 


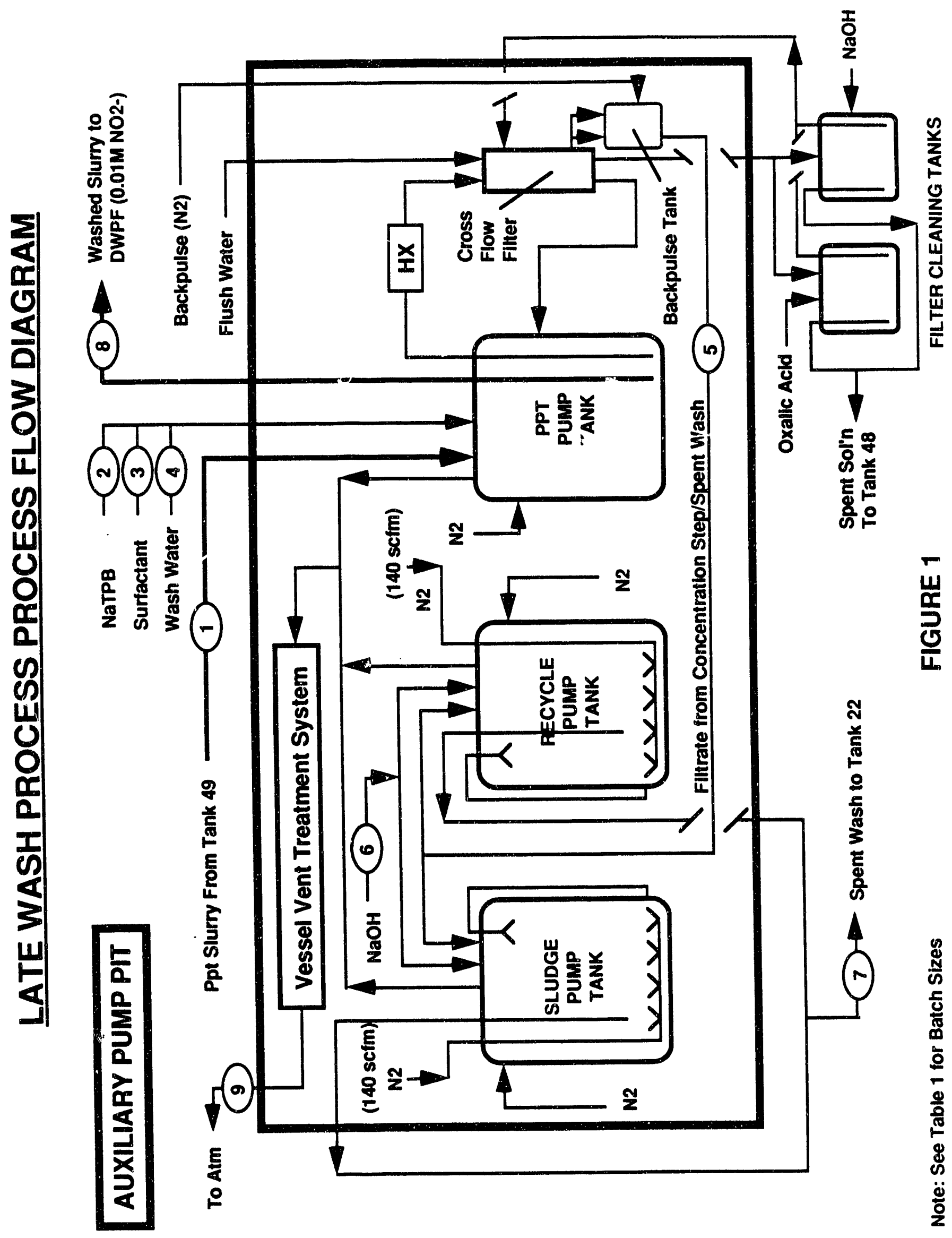




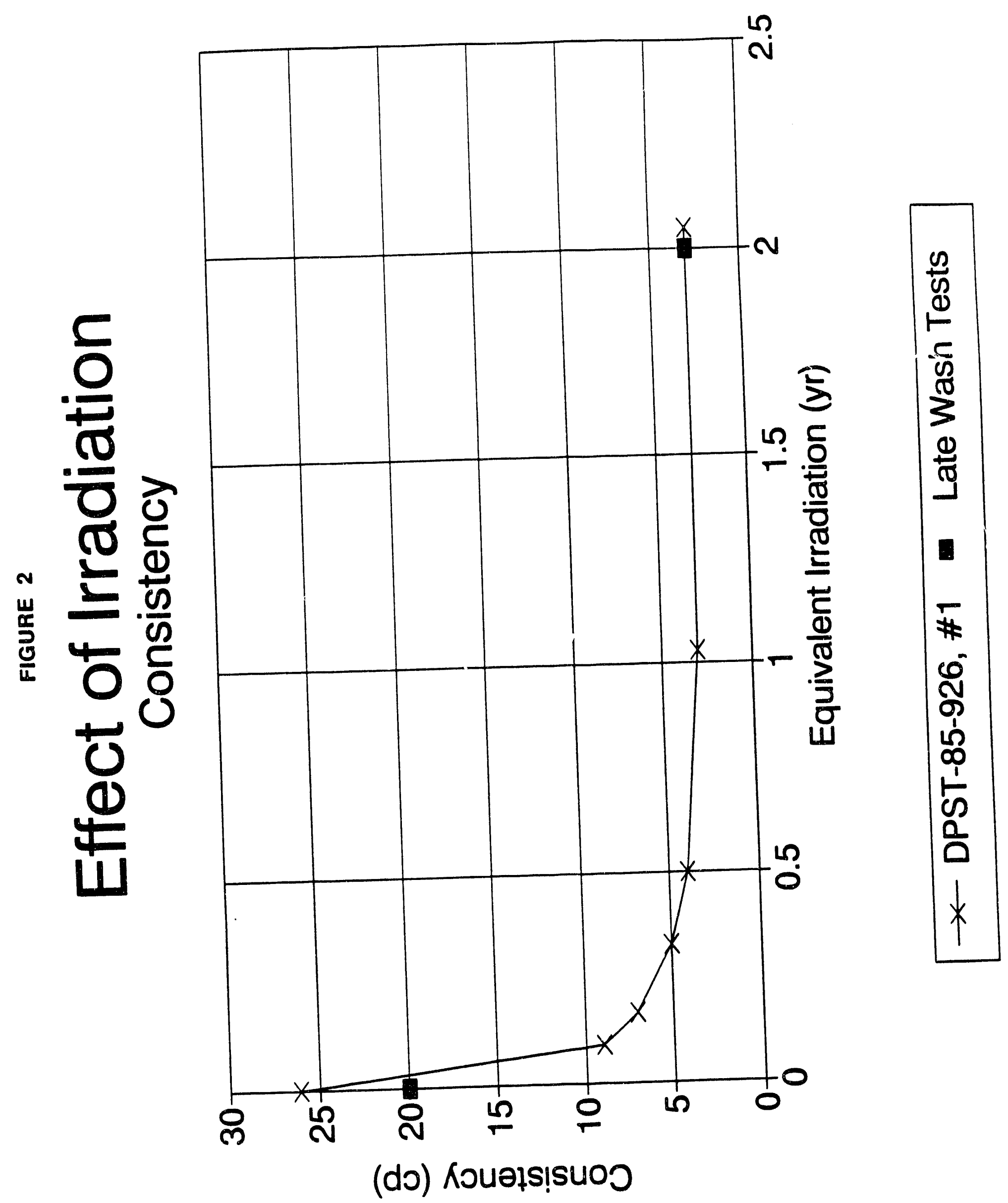




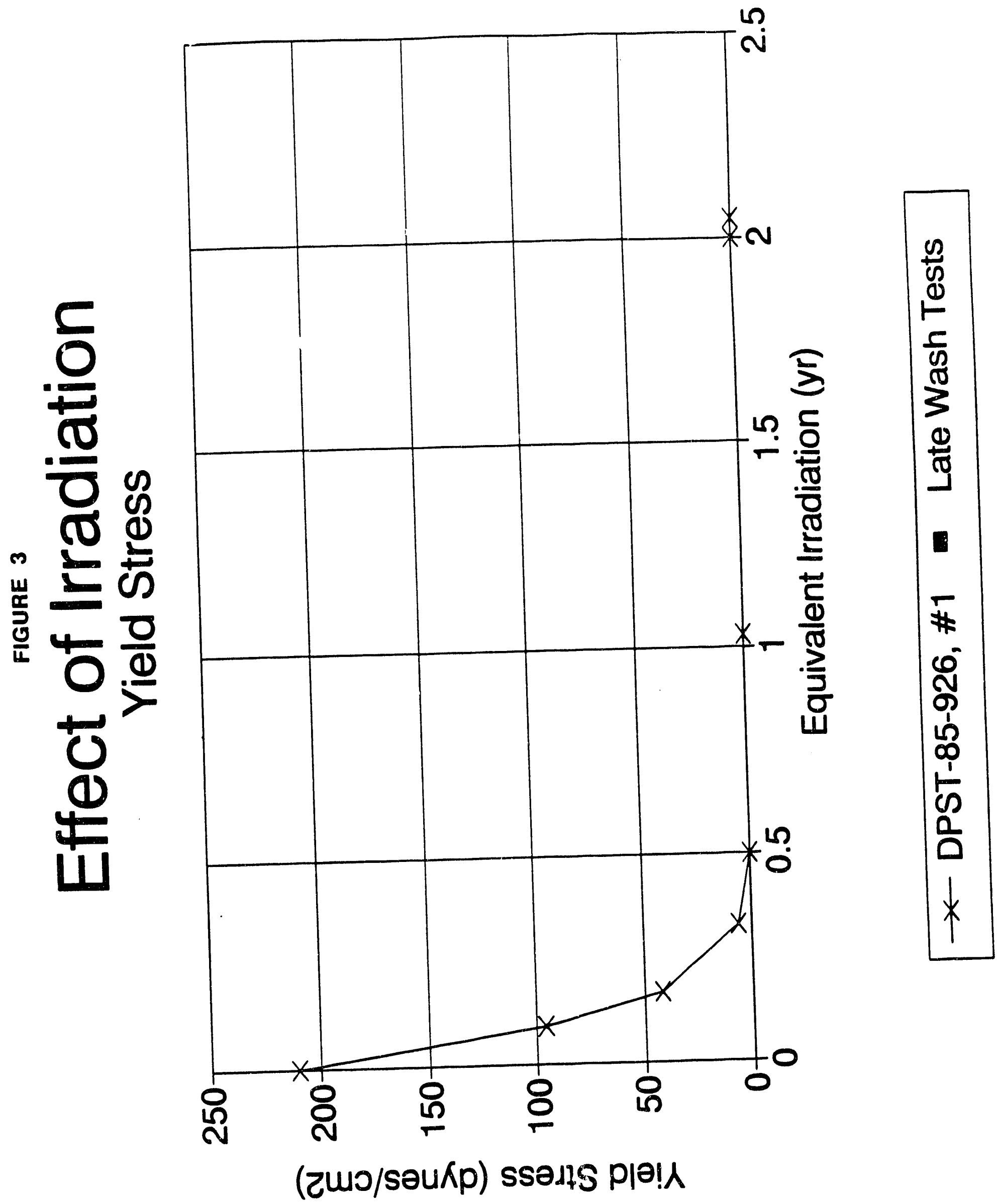


FIGURE 4

CEHG SPARGING \& SPRAYING OF RPT/SPT NO SURFYNOL WITH NaOH

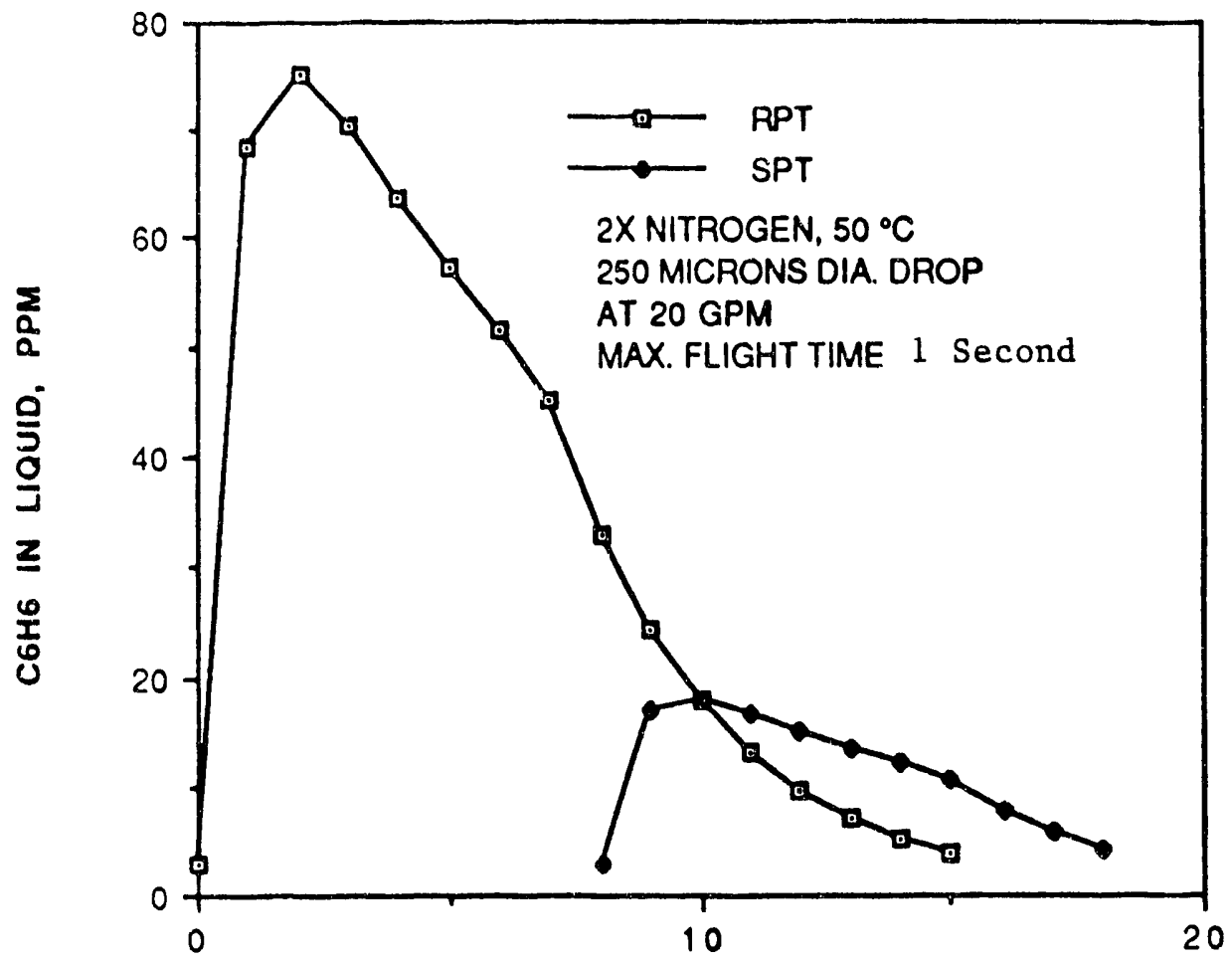

TIME, HR

CONDITIONS

Initial $\mathrm{C} 6 \mathrm{H} 6$ Concentration $-0.004 \mathrm{M}$

Spent Wash Generation Rate-9.2 gpm

No surfactant

Temperature $-50^{\circ} \mathrm{C}$

Sparge Rate - $1.24 \mathrm{scfm} / \mathrm{ft} 2$

Bubble Size - $2 \mathrm{~mm}$

Spray Droplet Size - $0.25 \mathrm{~mm}$

Spent Wash Spray Rate - $20 \mathrm{gpm}$

Maximum Flight Time of a Spray Droplet - $1 \mathrm{sec}$ 


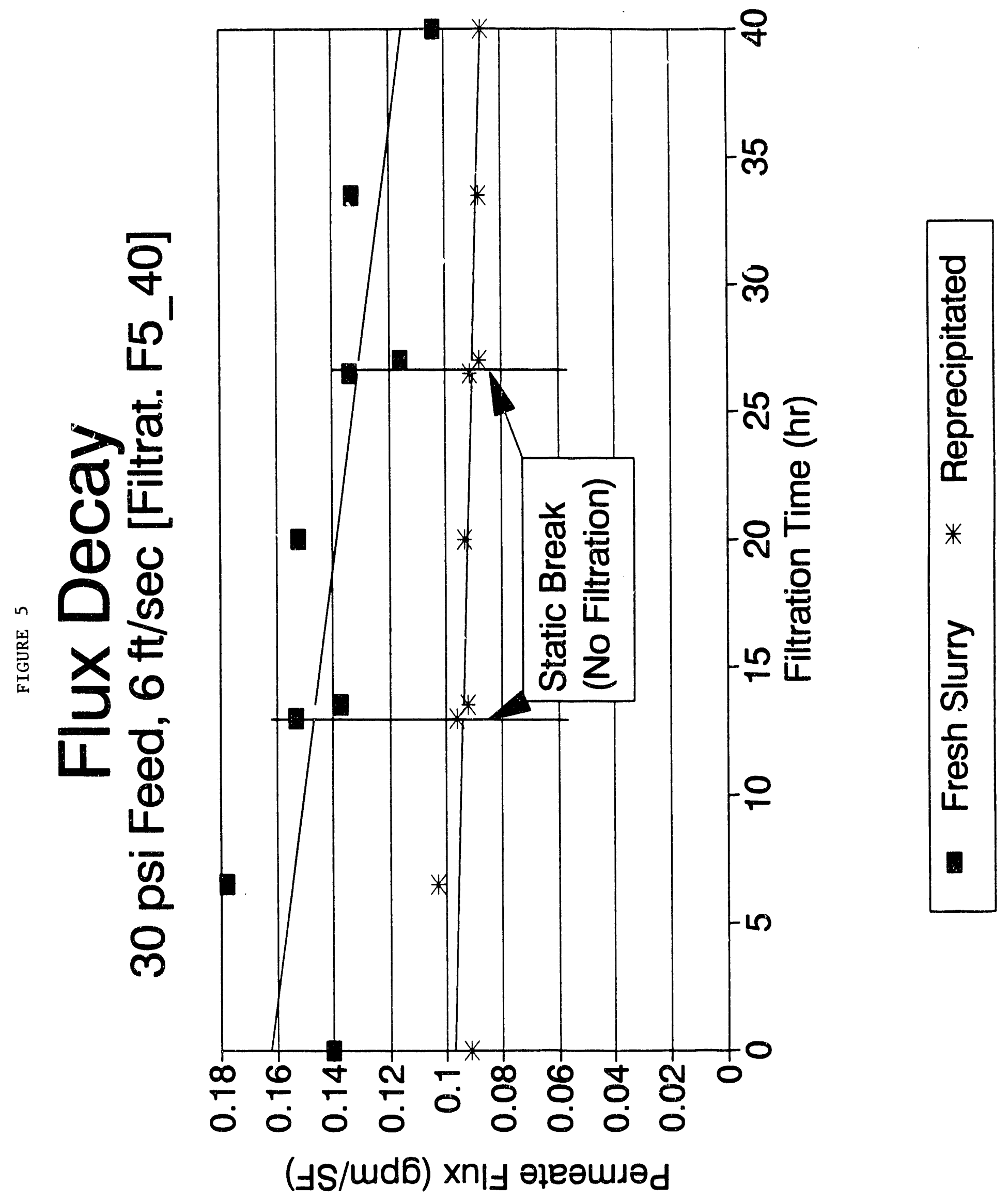


WESTINGHOUSE SAVANNAH RIVER COMPANY

WSRC-RP-92-793 (Rev 1)

SAVANNAH RIVER TECHNOLOGY CENTER

TABLE I

BATCH SIZES FOR LATE WASH FACILITY

(gallons)

$\begin{array}{clrc}\text { Stream_No } & \text { Stream Descriptlon } & \text { Beference Balance } & \text { Maximum_Batch_Sizes } \\ 4 & \text { Slurry from Tank } 49 & 3,096^{\mathrm{b}} & 3,091^{\mathrm{c}} \\ 2 & \text { NaTPB } & 5,15 & 335 \\ 4 & \text { Wash Water } & 8,269 & 8,749 \\ 5 & \text { Spent Wash } & 8,478 & 8,953 \\ 6 & 50 \text { wt\% NaOH } & 558 & 585 \\ 7 & \text { Inhibited Wash to Tank 22 } & 8,937 & 9,432 \\ 8 & \text { Washed Slurry to DWPF } & 3,429 & 3,438 \\ 9 & \text { Atmospheric Benzene Emissions } & \sim 7 \mathrm{~d} & \sim 7 \mathrm{~d}\end{array}$


TABLE \|

AVERAGE PERMEATE RATE - 40 HOUR FILTRATION (GPM/FT2)

Linear Velocity (ft/sec)

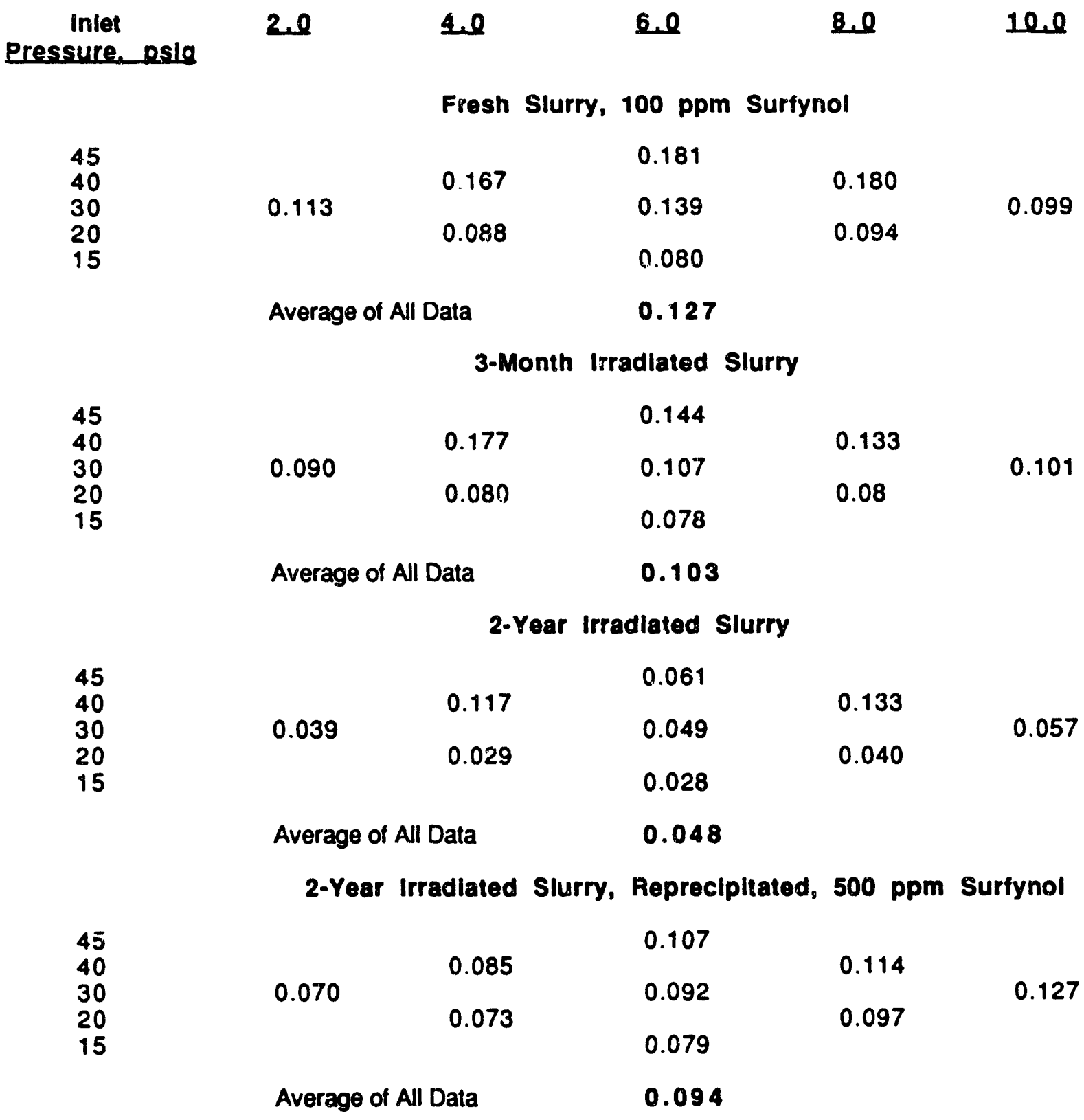

a - from Reference 4 


\section{APPENDIX A}

\section{LATE WASH FACILITY MATERIAL BALANCE}

\section{Calculational Bases}

\section{In-Tank Precipitation}

- Tank 48 slurry temperature $-60^{\circ} \mathrm{C}$

- Following the final ITP precipitation and concentration steps, the aqueous fraction of the slurry in Tank 48 is washed to less than $0.20 \mathrm{M}$ nitrate while maintaining at least $1.20 \mathrm{M}$ free hydroxide by adding $50 \mathrm{wt} \% \mathrm{NaOH}$

- Washing is continued, inhibiting with $\mathbf{4 0}$ wt\% NaNO2 until the following criterion is met:

$\left[\mathrm{NO}^{-}\right]+\left[\mathrm{NO}^{-}\right]=0.30 \mathrm{M}$

- The target inhibitor concentration is set at 1.5 times that determined by the following algorithm:

$$
\begin{aligned}
& \log \left[\mathrm{NO2}^{-}\right)=-0.984+0.0319 \mathrm{~T}+1.79 \log \left[\mathrm{NO}^{-}\right]+0.472\left(\log \left[\mathrm{NO}^{-}\right]\right)^{2} \\
& T=\text { slurry temp, }{ }^{\circ} \mathrm{C}[2] \\
& {\left[\mathrm{NO2}^{-}\right],\left[\mathrm{NO}^{\circ}\right]=\mathrm{M}}
\end{aligned}
$$

- Washing is continued until the following critcrion is met:

$$
\left[\mathrm{NO}^{-}\right]+\left[\mathrm{NO}^{-}\right]=0.30 \mathrm{M}
$$

\section{Iank 49 Storage}

Precipitate is stored for 2 years with a Cs-137 cuncentration of $36 \mathrm{Ci} / \mathrm{gal}$

$\mathrm{Cs} / \mathrm{NH} 4 / \mathrm{K}$ solids go into solution at a rate of $6.5 \%$ per year.

Rate of consumption of hydroxide $-0.01 \mathrm{M}$ per month

- Rate of radiolytic conversion of nitrate to nitrite $-0.15 \mathrm{M}$ per year until the firial equilibrium [NO3'] concentration of $0.002 \mathrm{M}$ is reached

- Rate of radiolytic destruction of nitrite $-0.075 \mathrm{M}$ per year

\section{Late Washing}

- 240 gallons of cross-flow filter "layup" water is drained into the PPT before reprecipitation

- Operating heel in PPT - 650 gallon

- NaTPB addition is based on the stoichiometric amount required to precipitate soluble $\mathrm{K}^{+}$, $\mathrm{NH}^{+}$and $\mathrm{Cs}^{+}$plus an excess to adjust the TPB- concentration in the aqueous fraction to $0.004 \mathrm{M}$ or greater.

- The insoluble solids are concentrated to $10 \mathrm{wt} \%$ before initiating washing

- Wash water contains $0.004 \mathrm{M}$ NaTPB

- Washing endpoint - $0.01 \mathrm{M}$ nitrite (aqueous fraction)

- Benzene content of spent wash is stripped into the vessel vent system until the residual benzene content is $s 5 \mathrm{ppm}$. The benzene content in aqueous fraction of slurry batch from Tank 49 is projected to be $0.004 \mathrm{M}$ [3]

- Hydroxide content of spent wash is adjusted to $1.2 \mathrm{M}$ before transfer to Tank 22

- Instantaneous slurry flow to DWPF $=1.33 \mathrm{gpm}$ based on $10 \mathrm{wt} \%$ insoluble solids content

Additional calculational bases are found in WSRC-TR-92-211. 


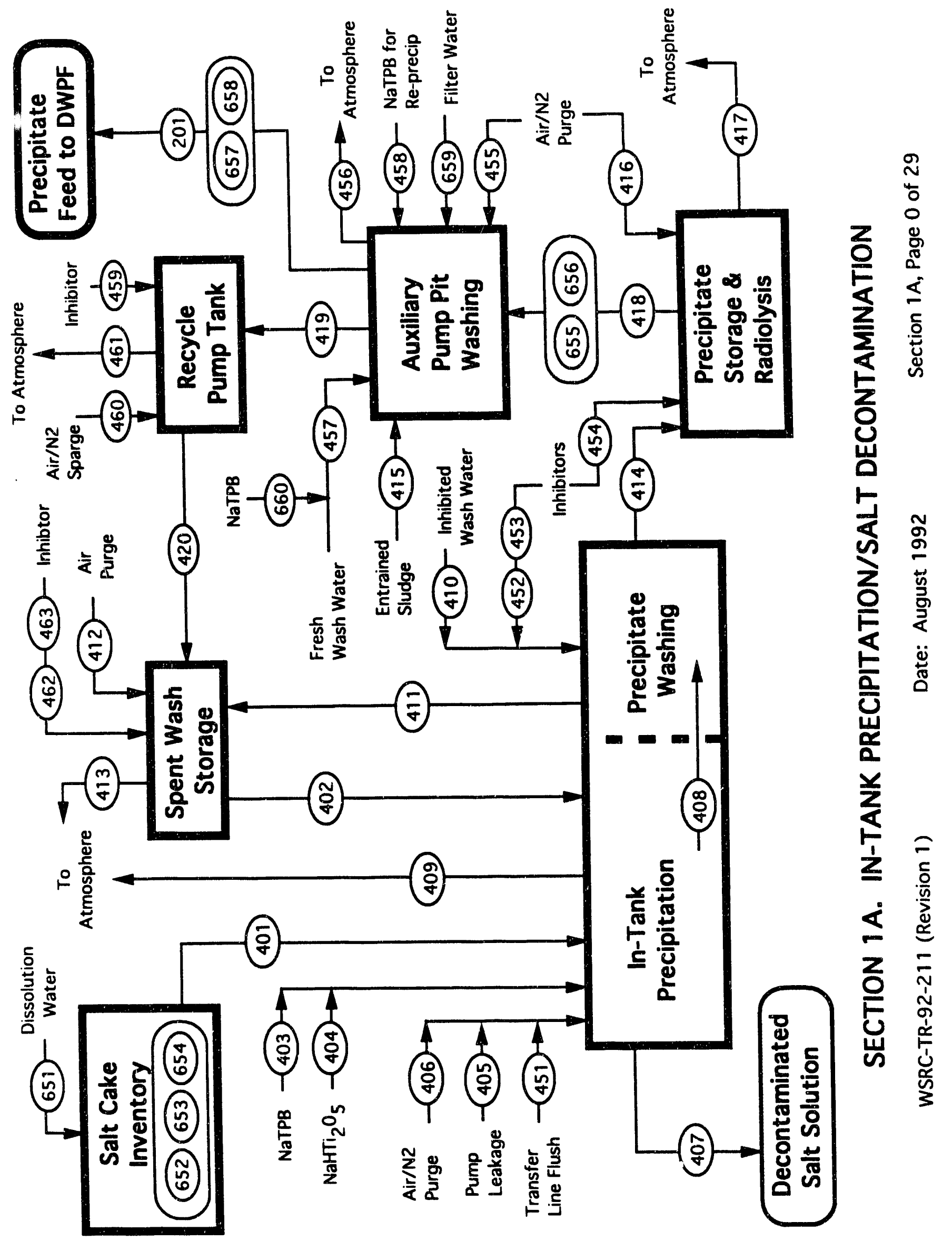




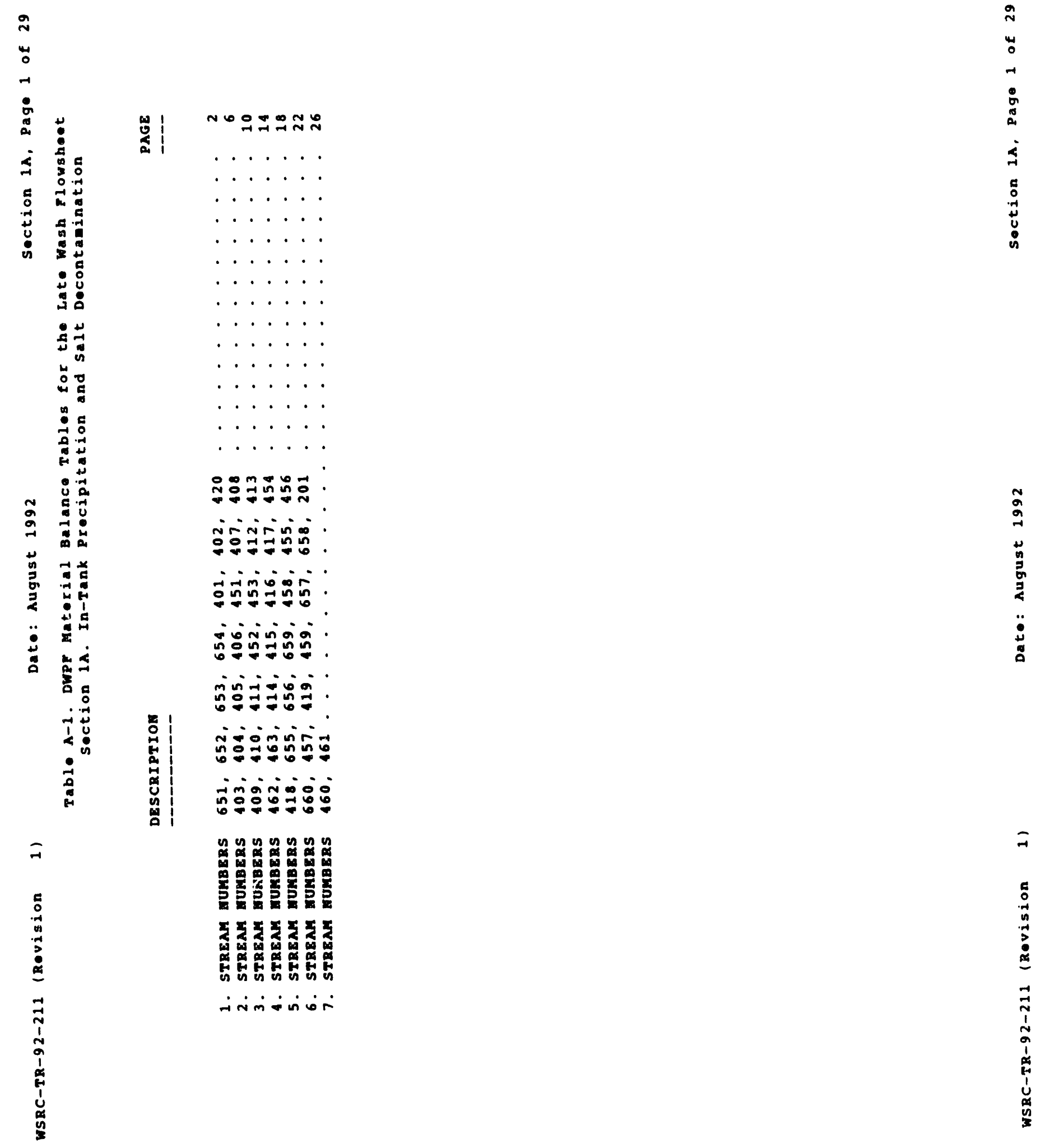




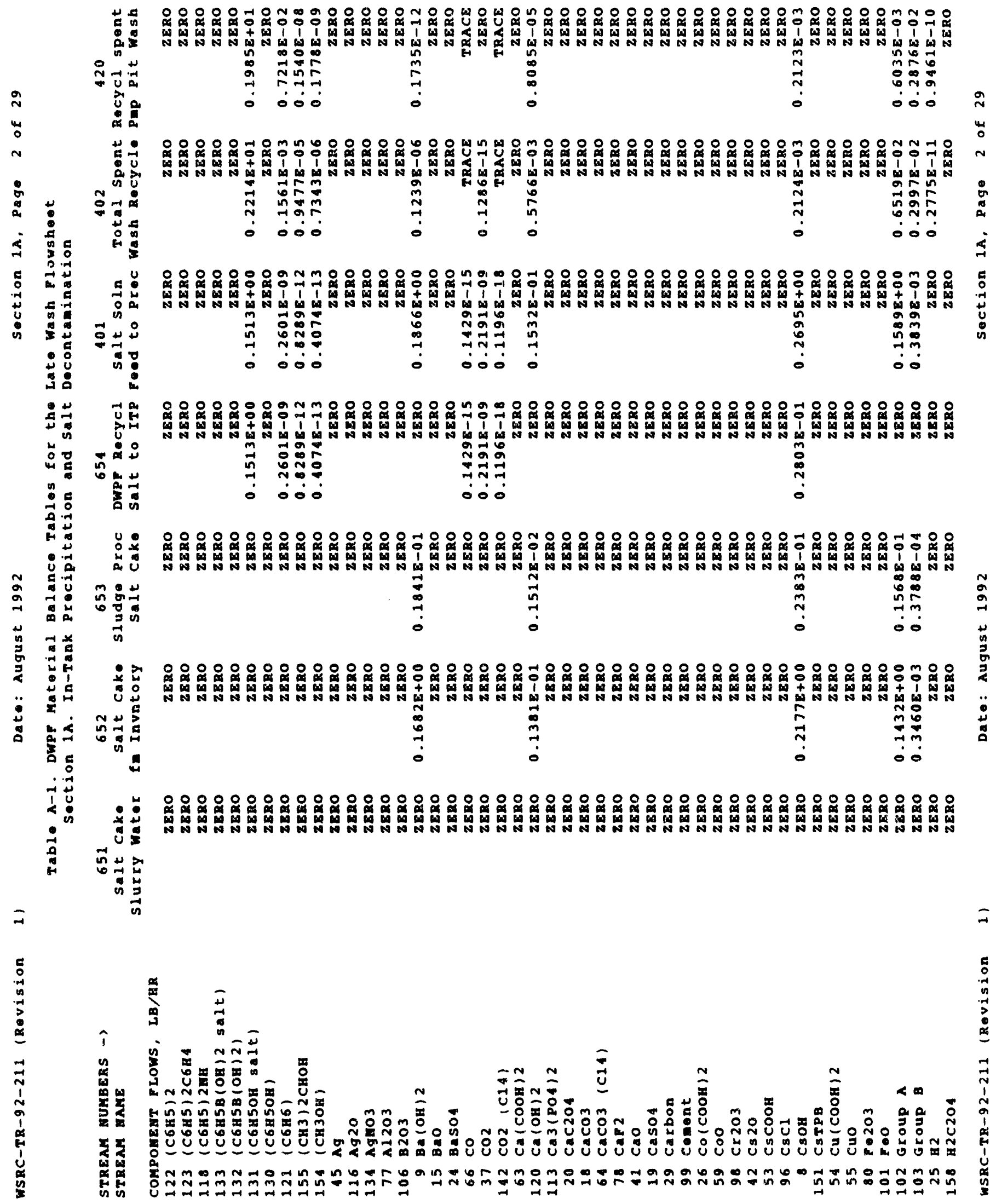




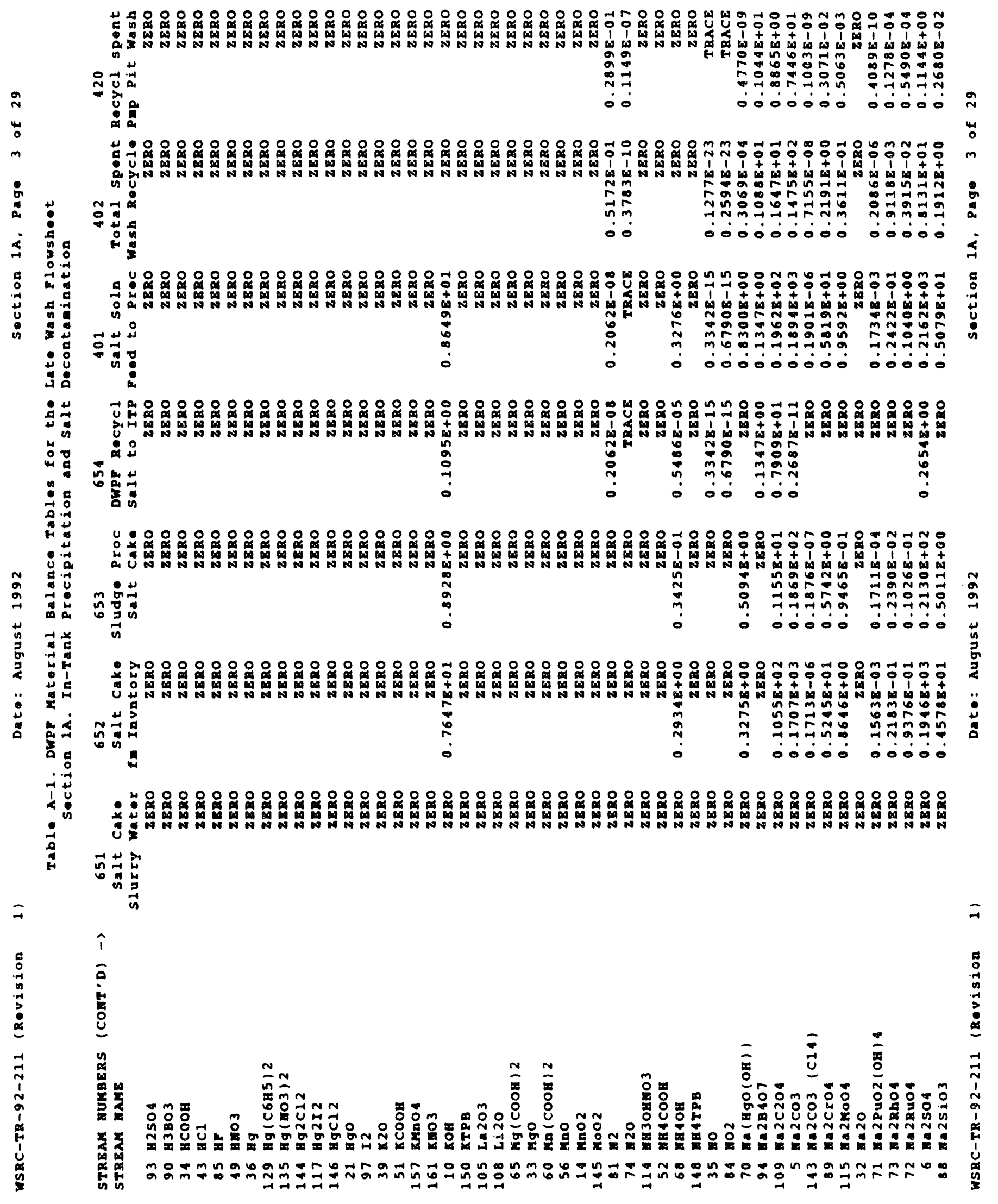




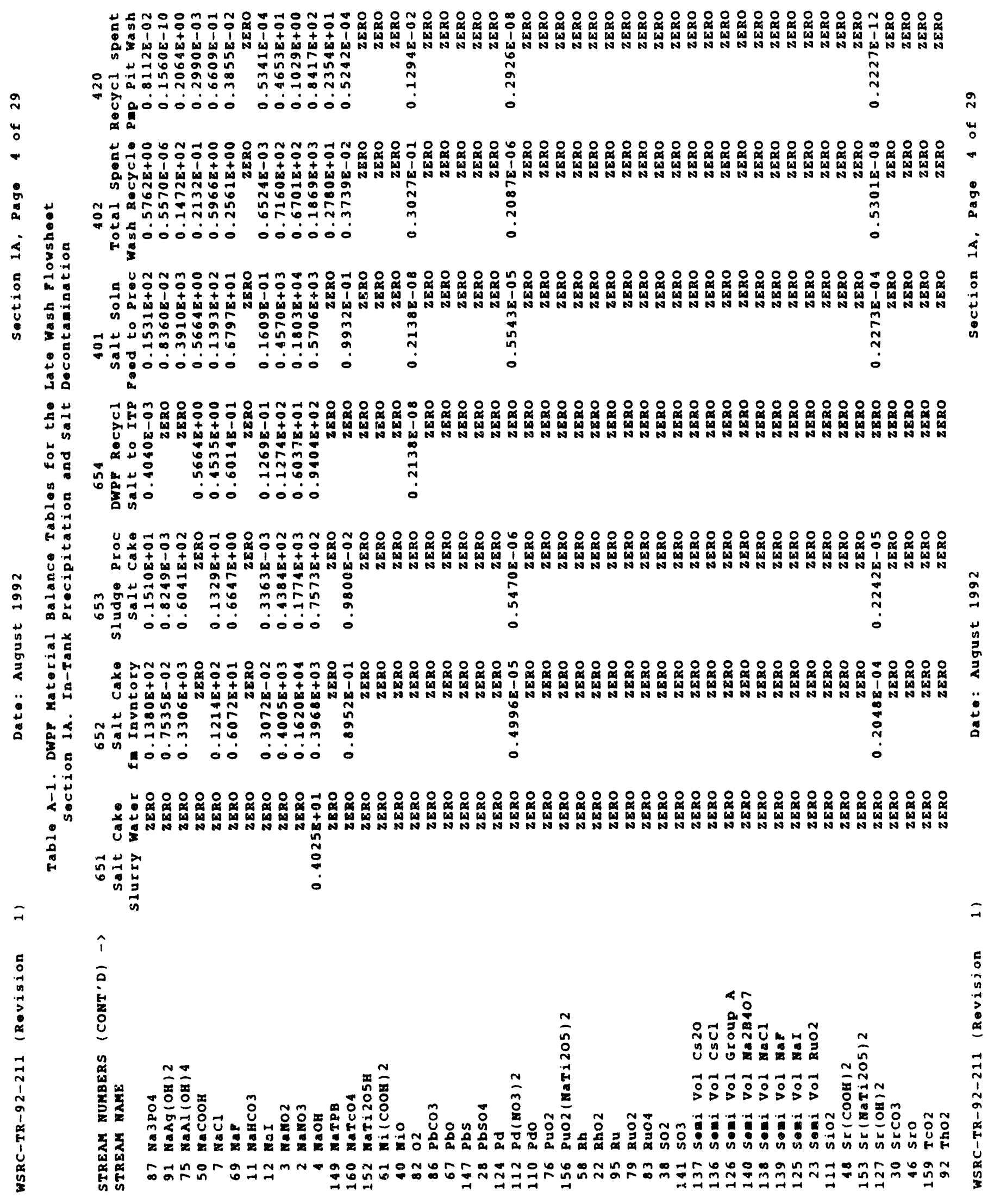




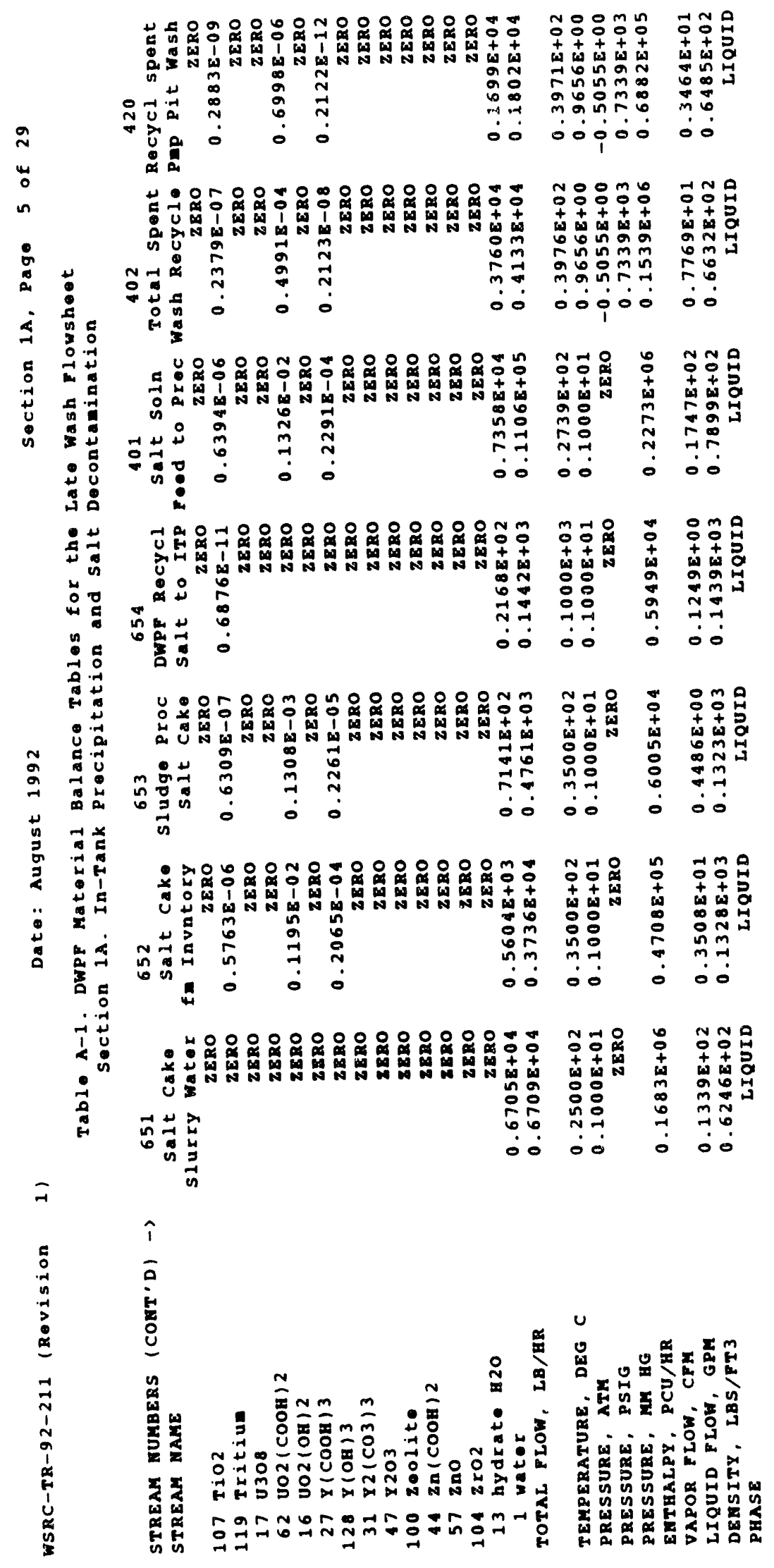

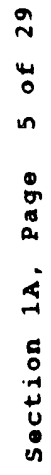

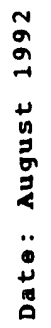




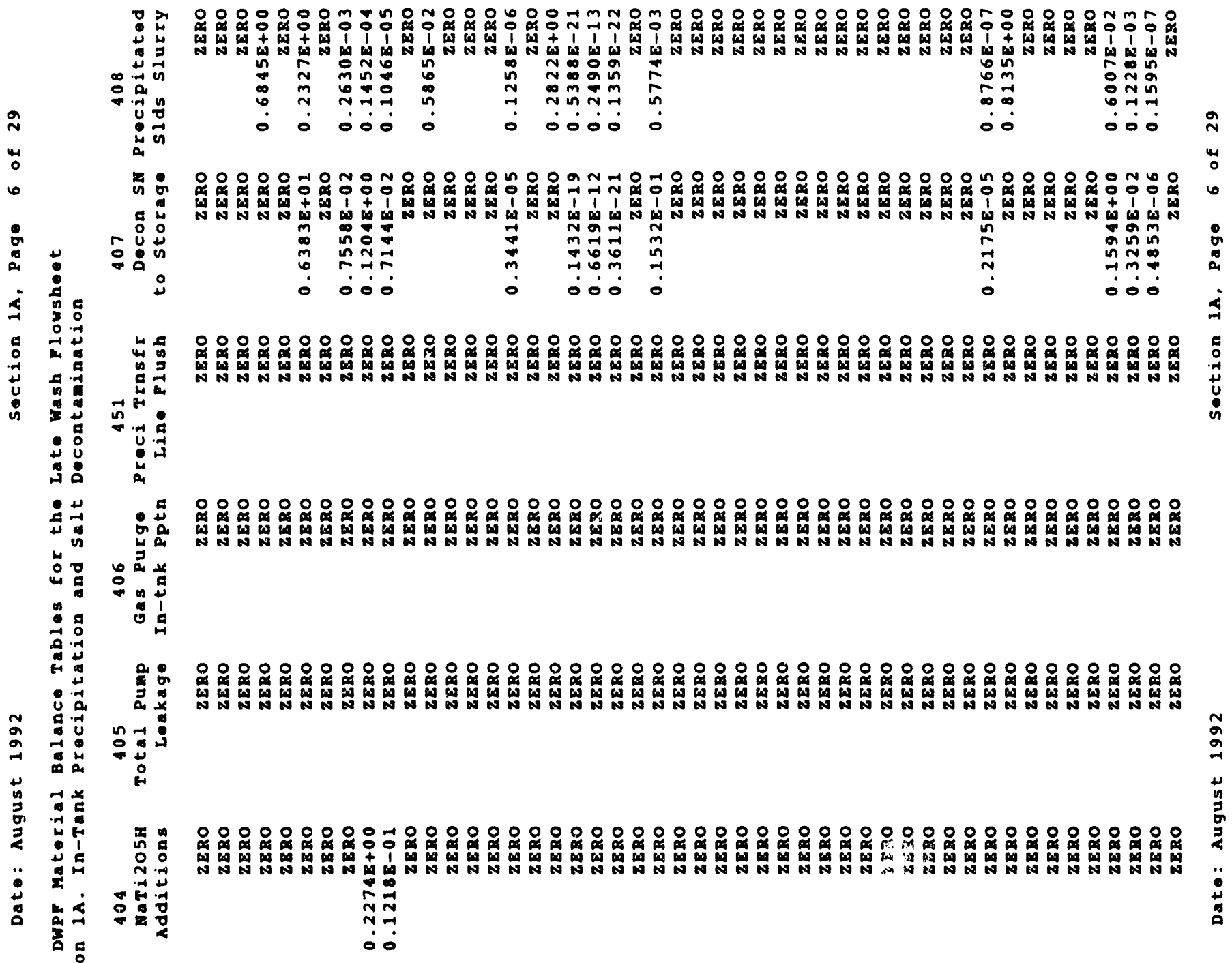

吉皆

$\stackrel{9}{\circ}$

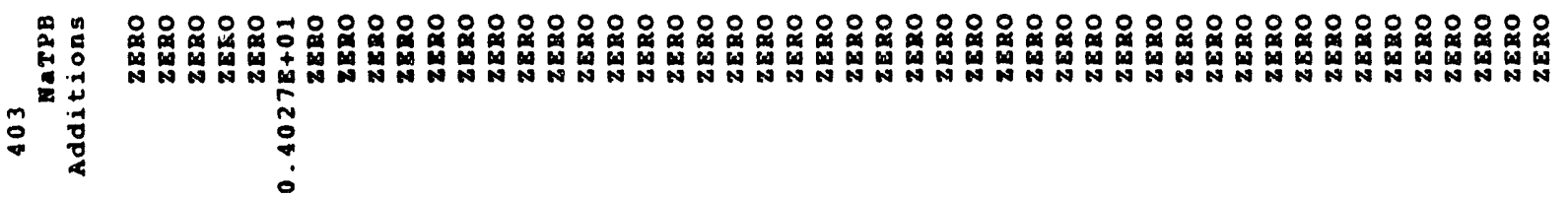




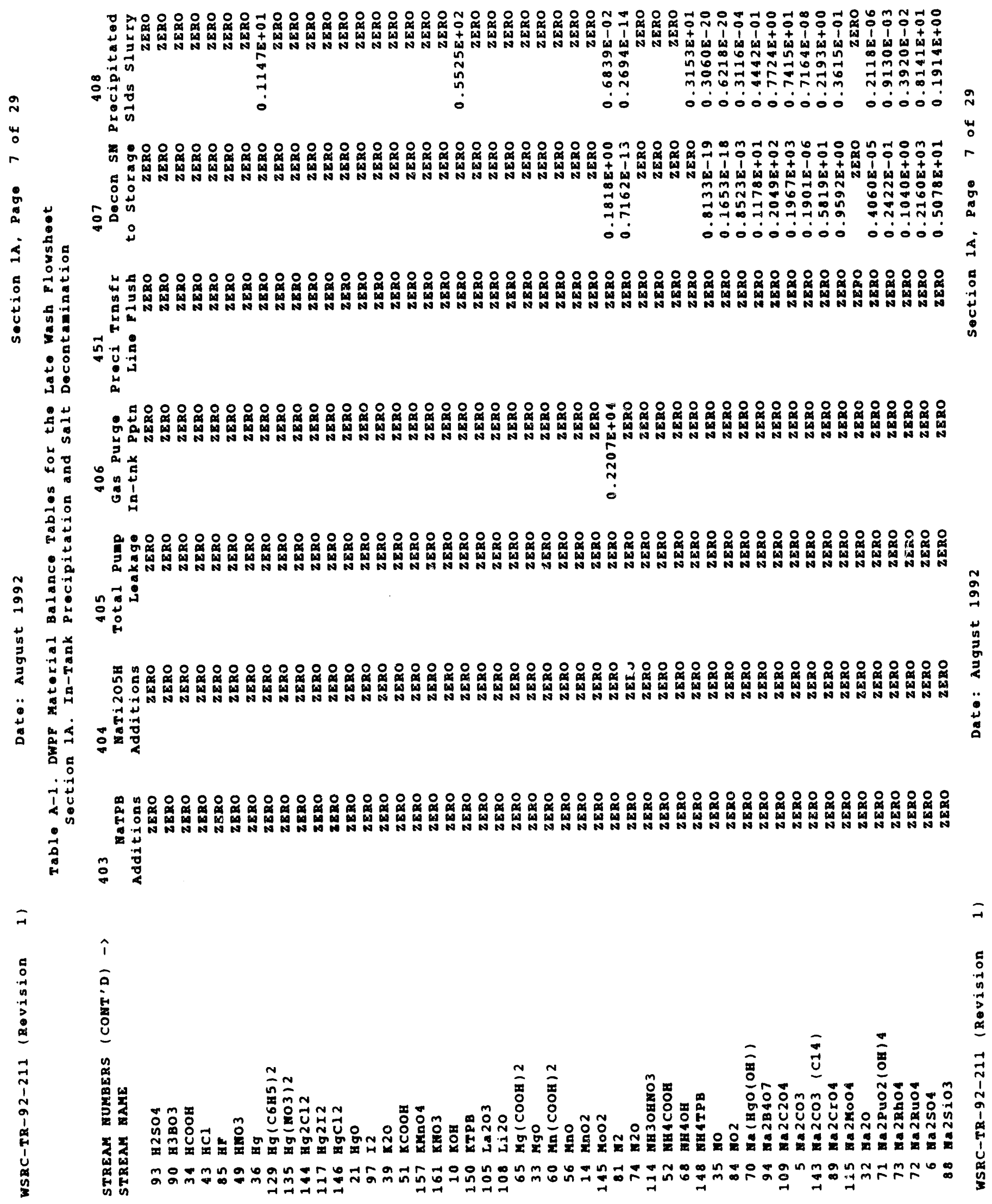




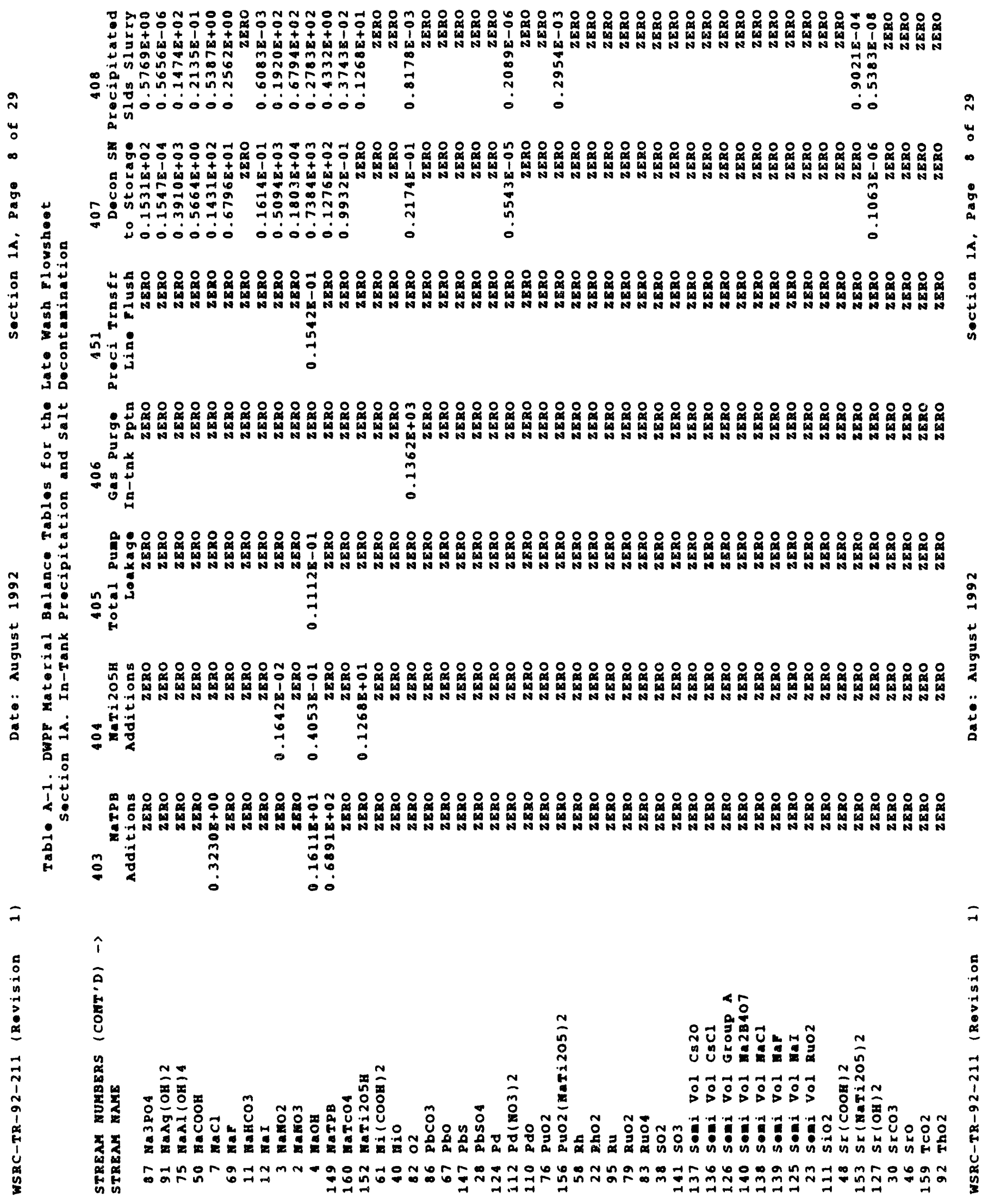




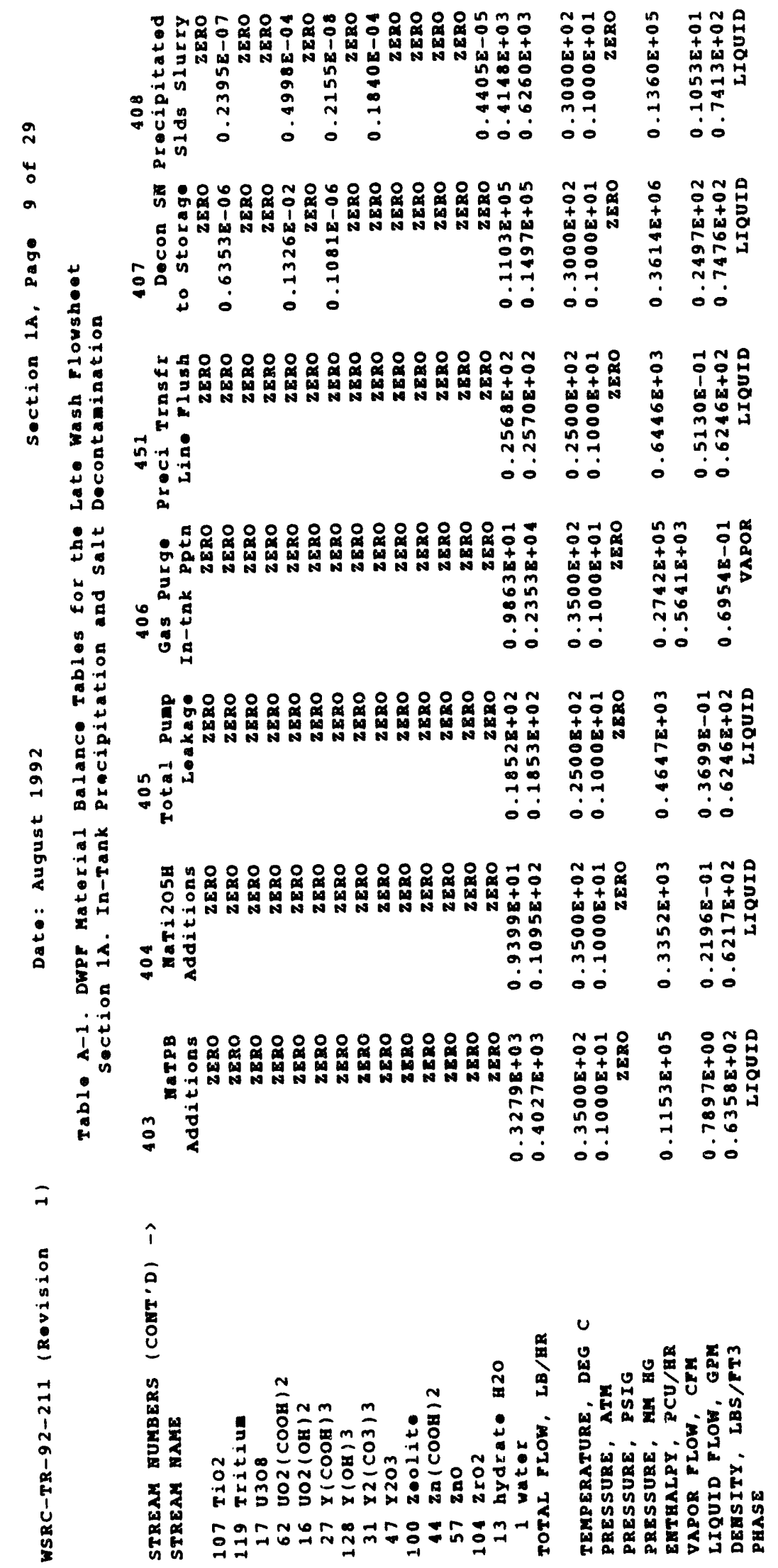

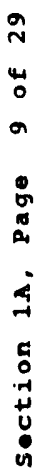




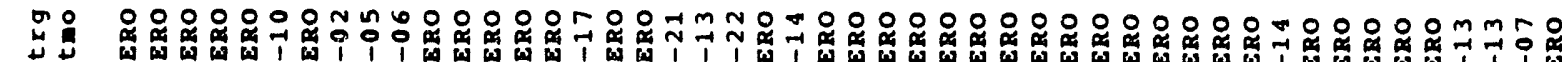

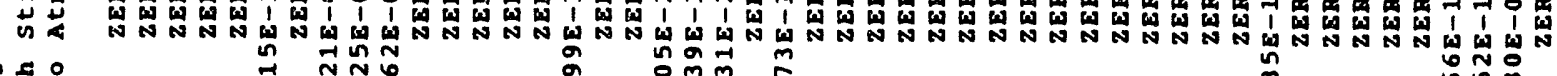

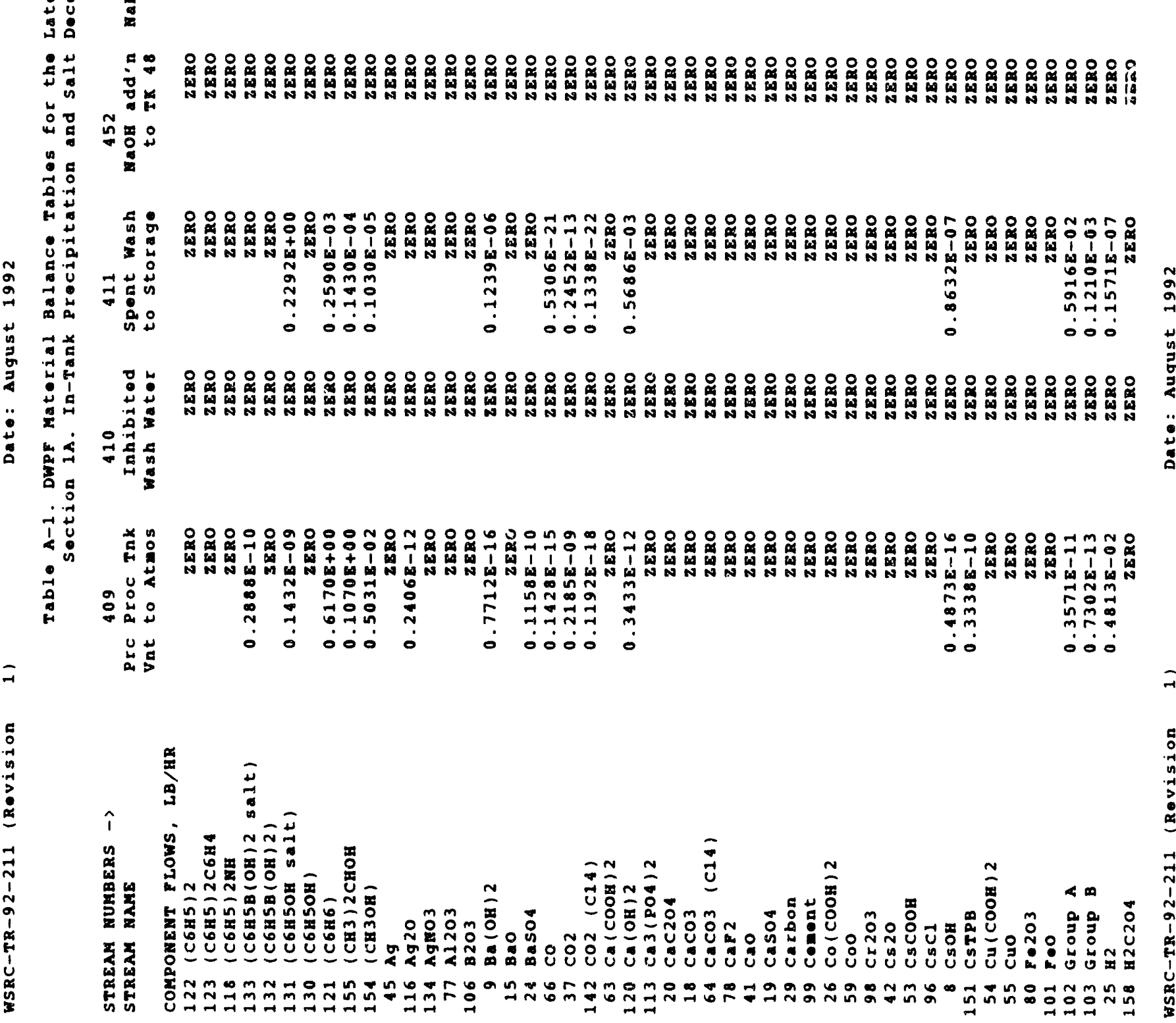




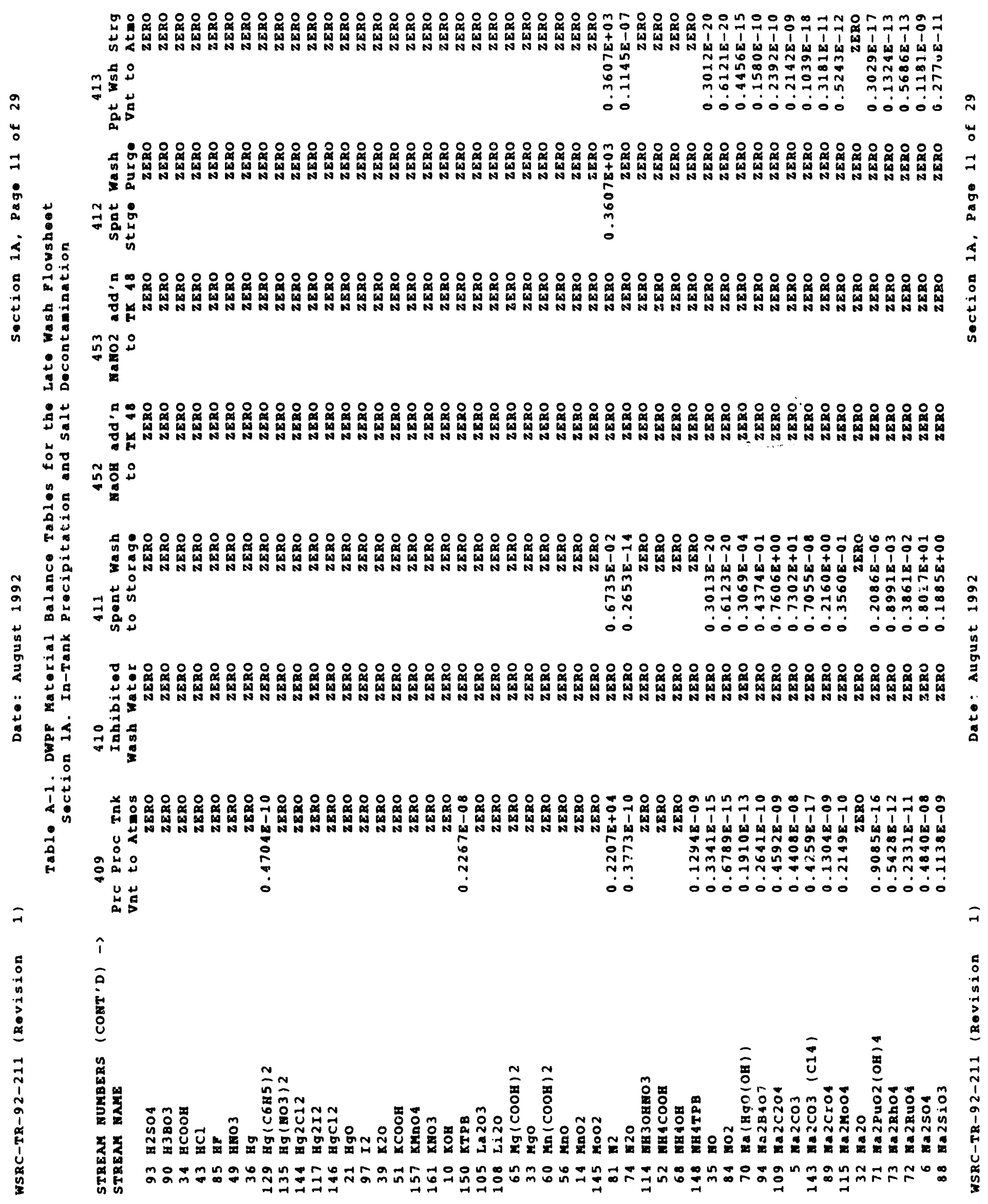




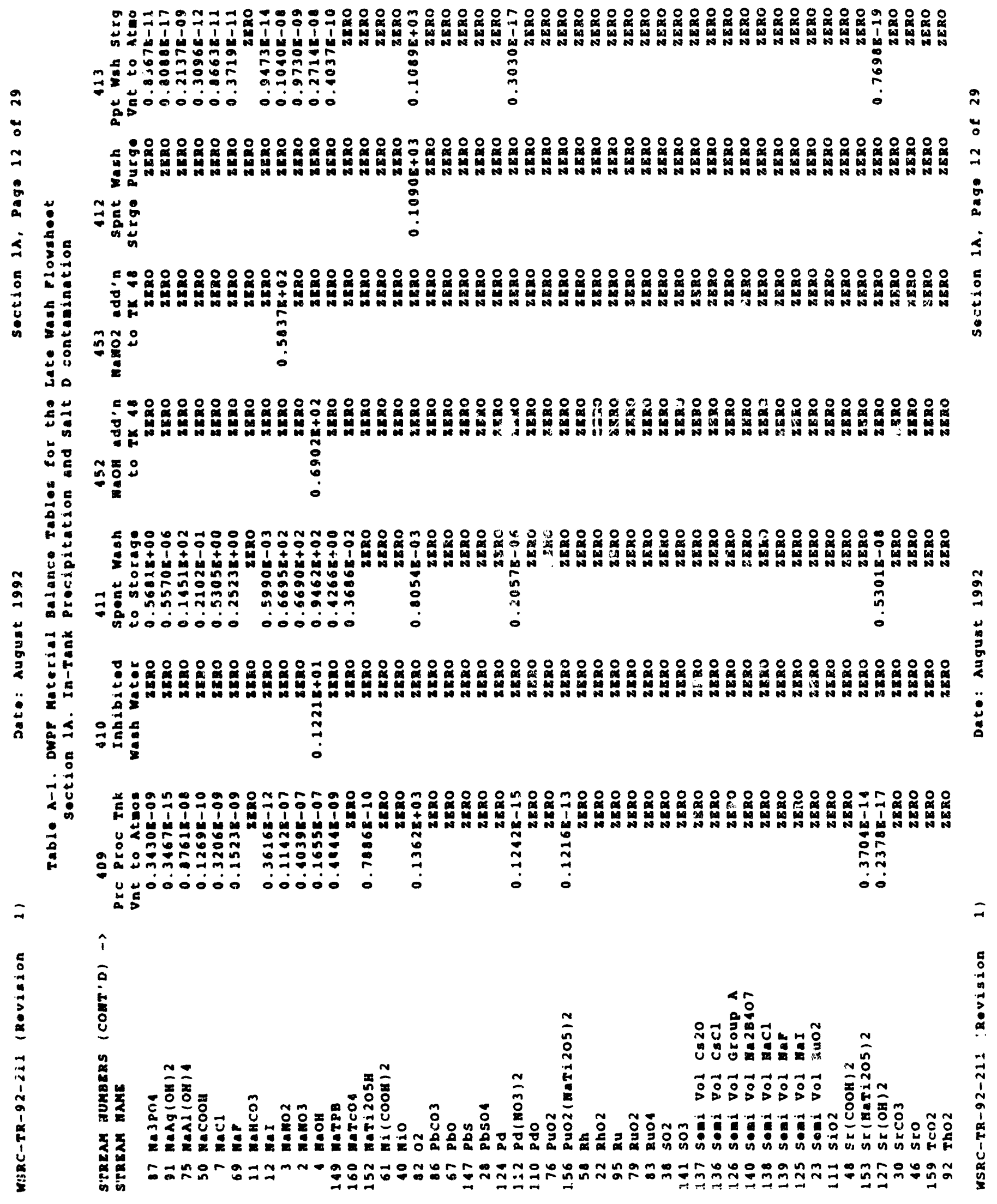




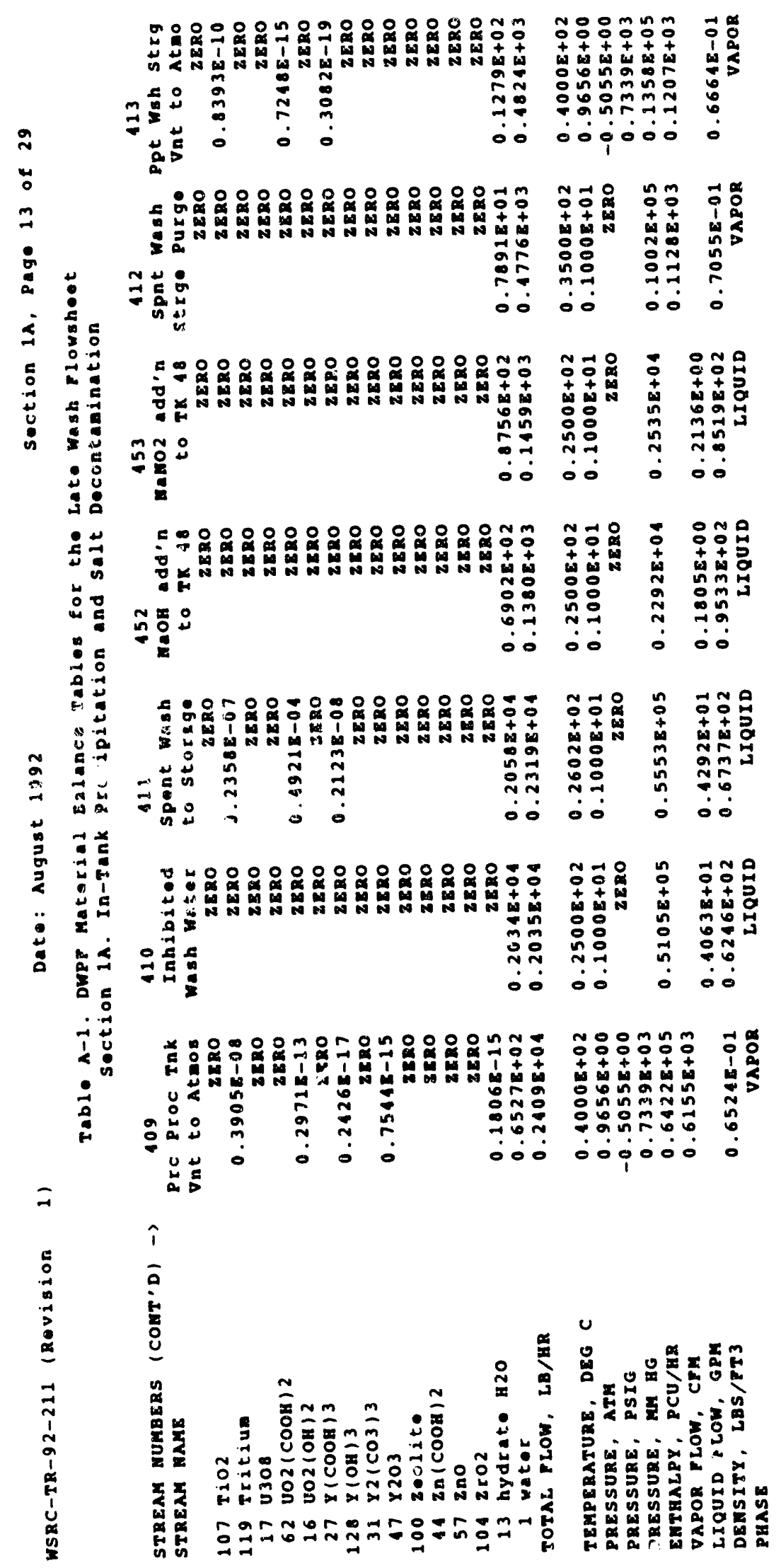

2
$\vdots$
0
3
$\vdots$
$\vdots$
$\vdots$
$\vdots$
$\vdots$
$\vdots$
$\vdots$
0
0 


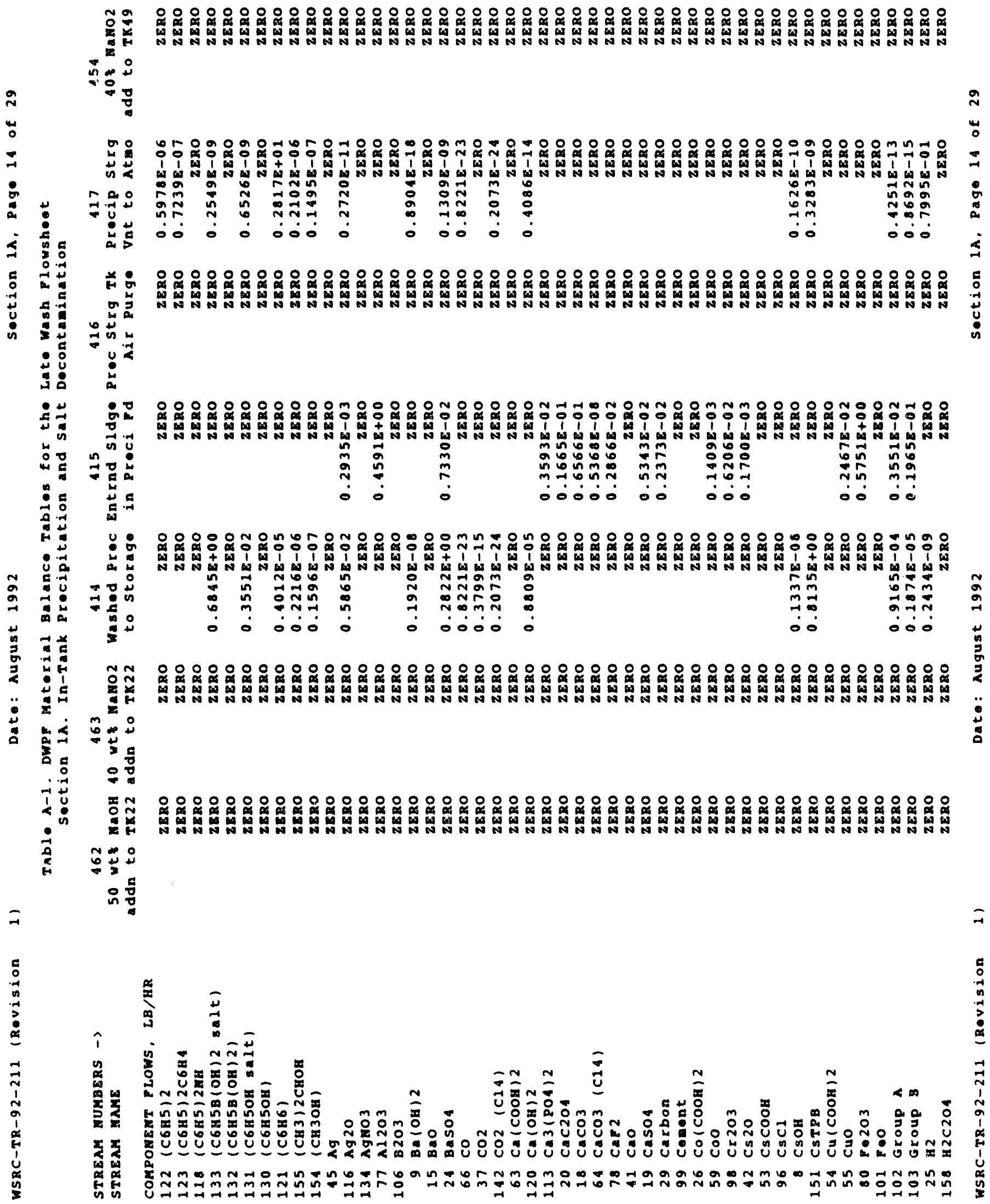




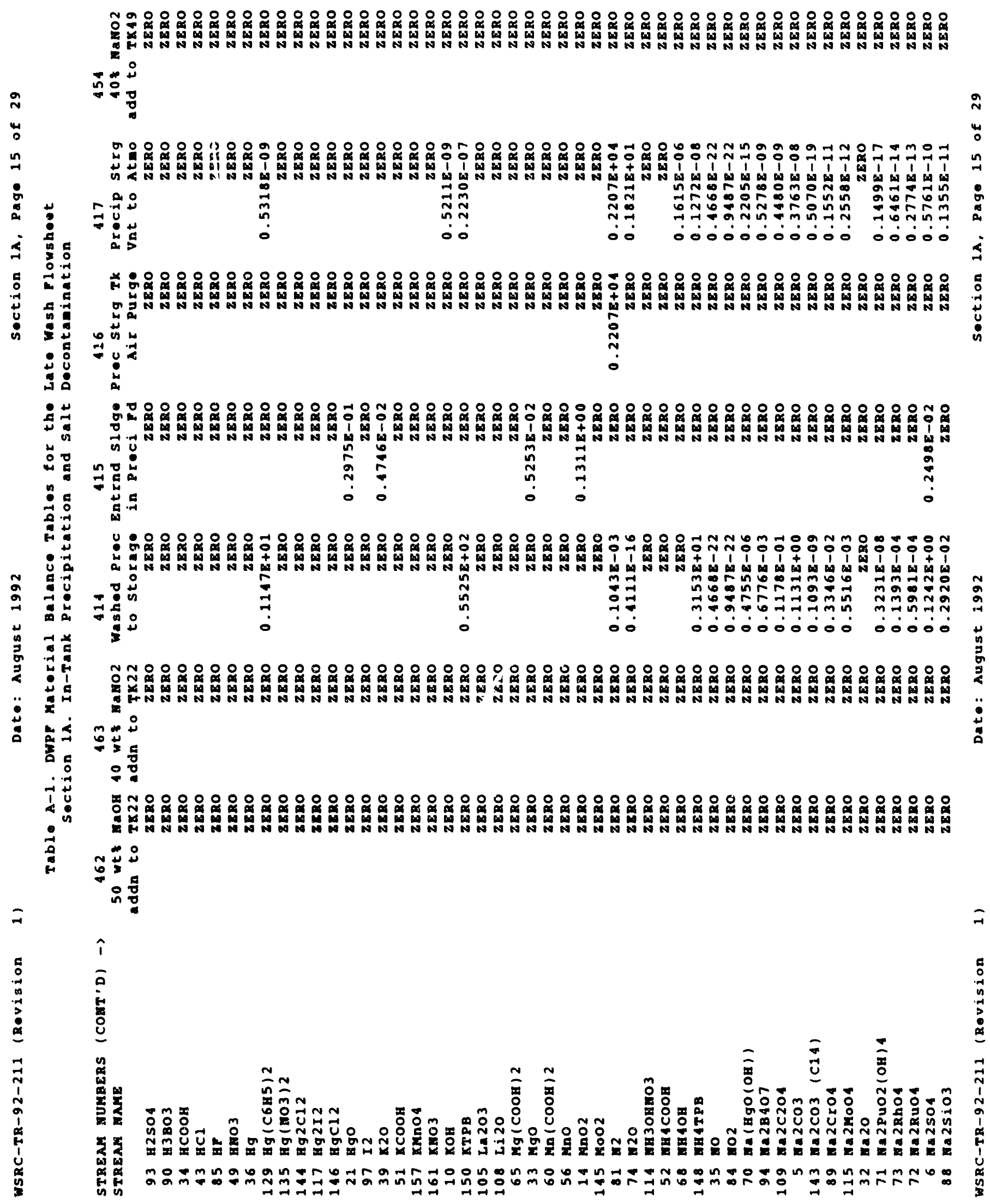




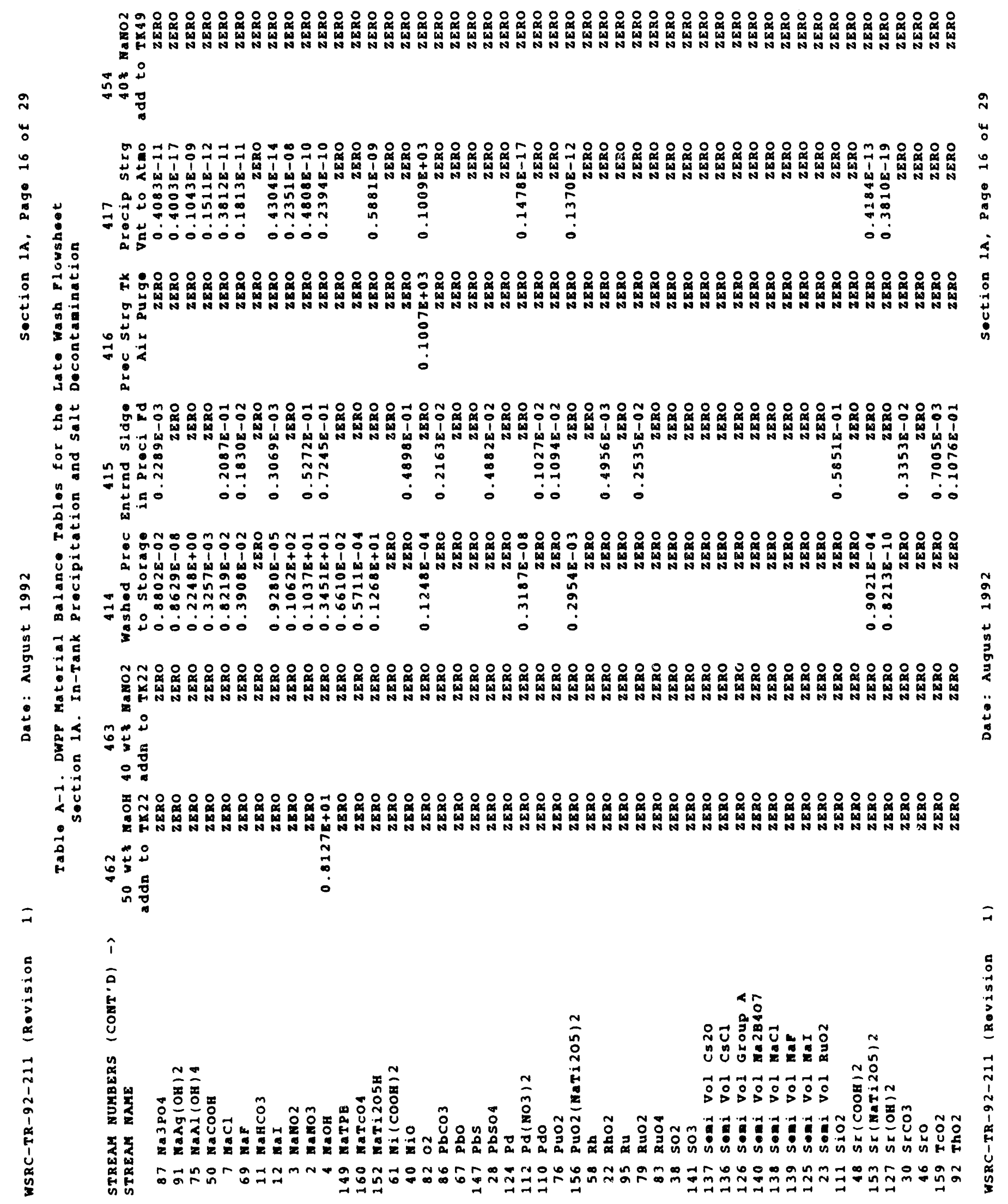




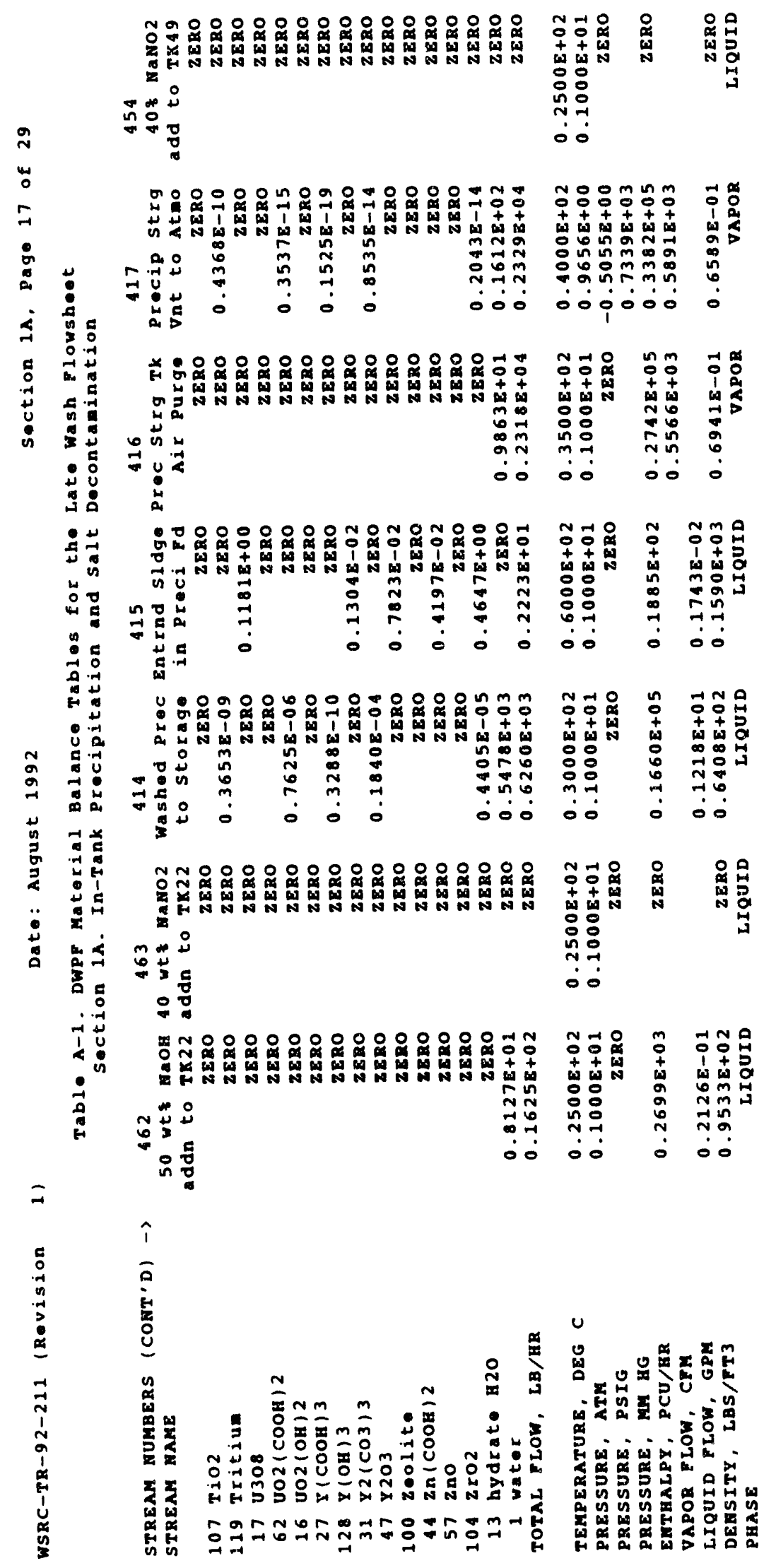

2
4
0
$\vdots$
$\vdots$
$\vdots$
$\vdots$
$\vdots$
$\vdots$
$\vdots$
5
$\vdots$
0
0
0
0

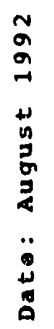

$=$

5
0
0
0
0
0
0
0 


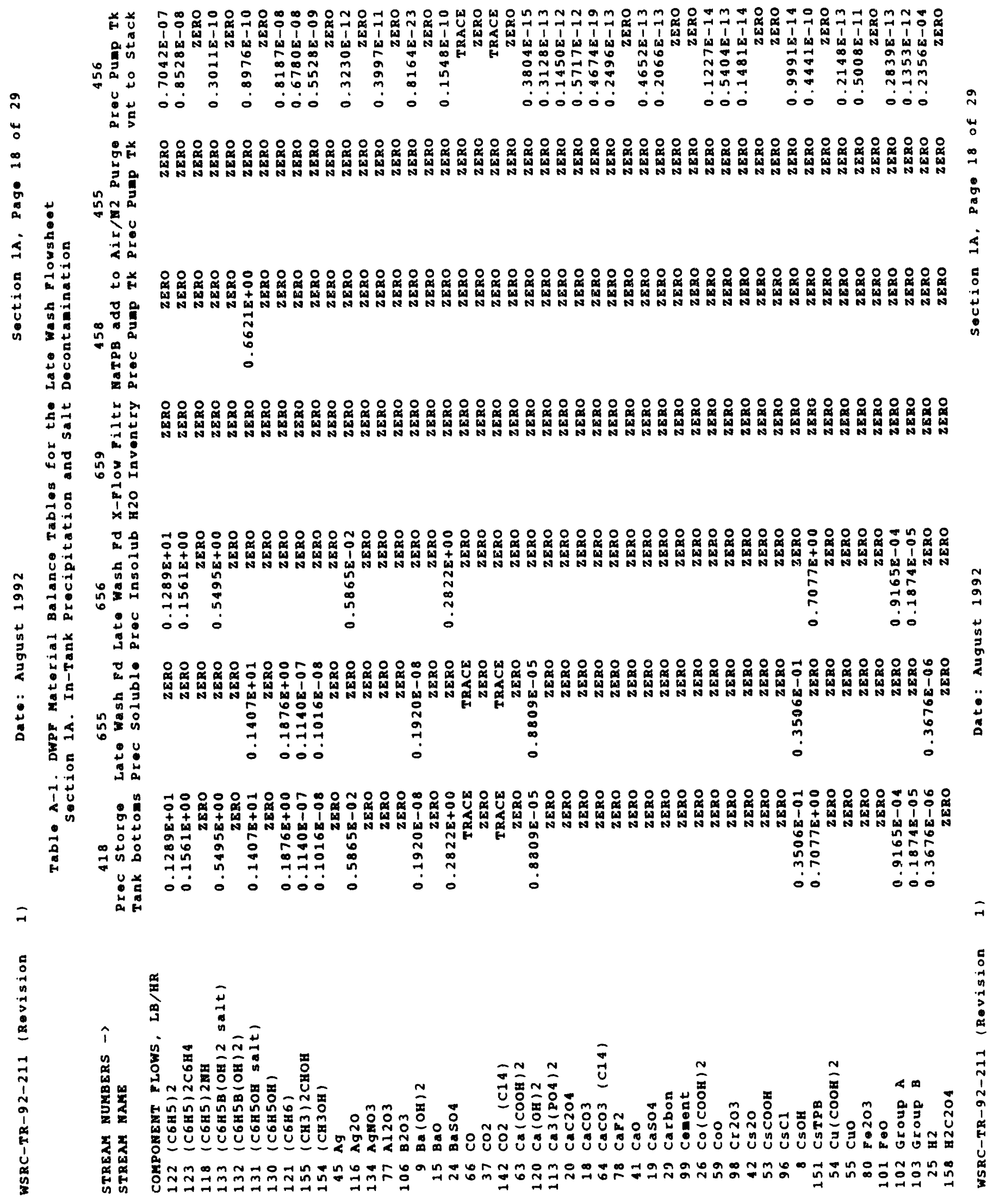




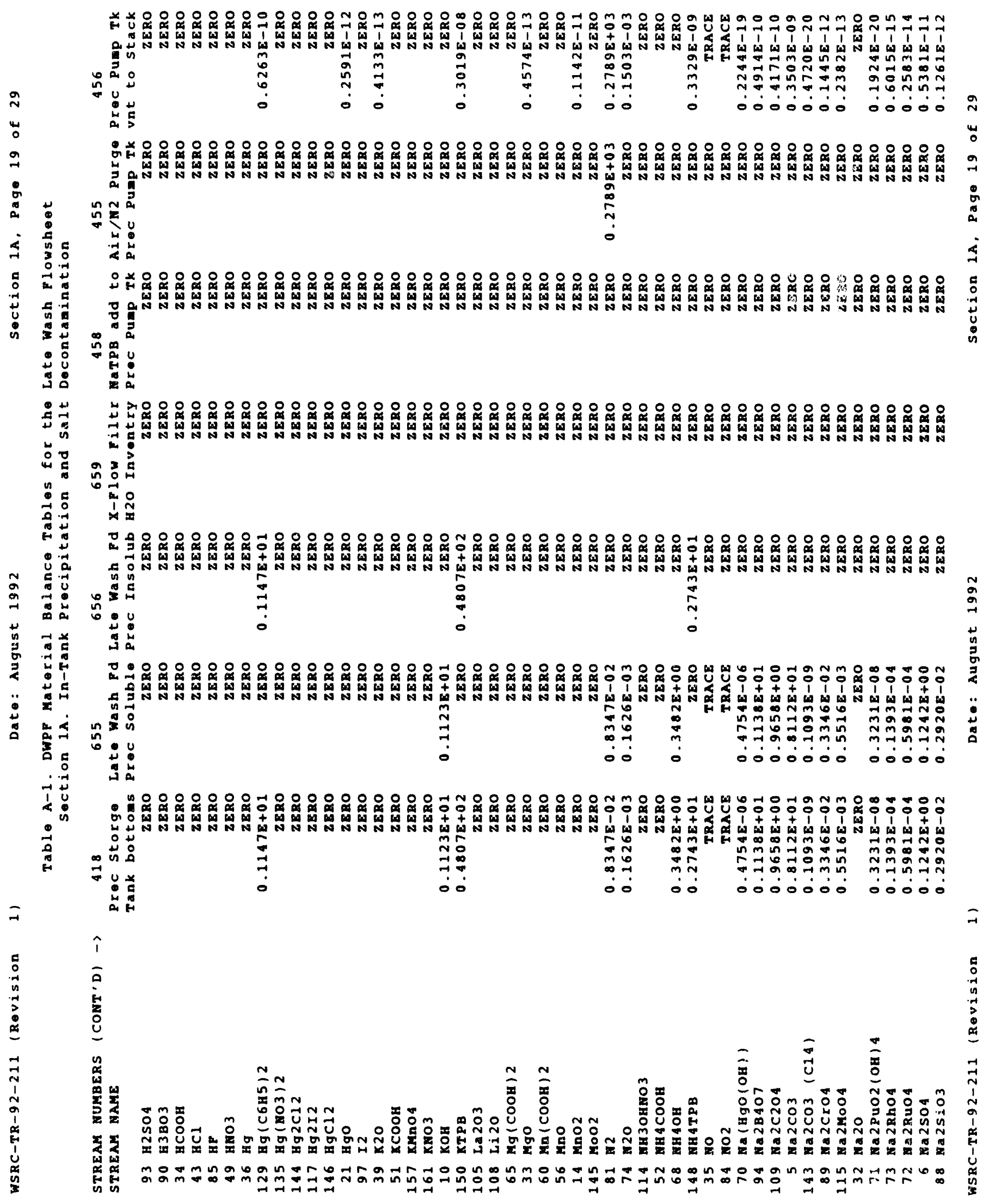




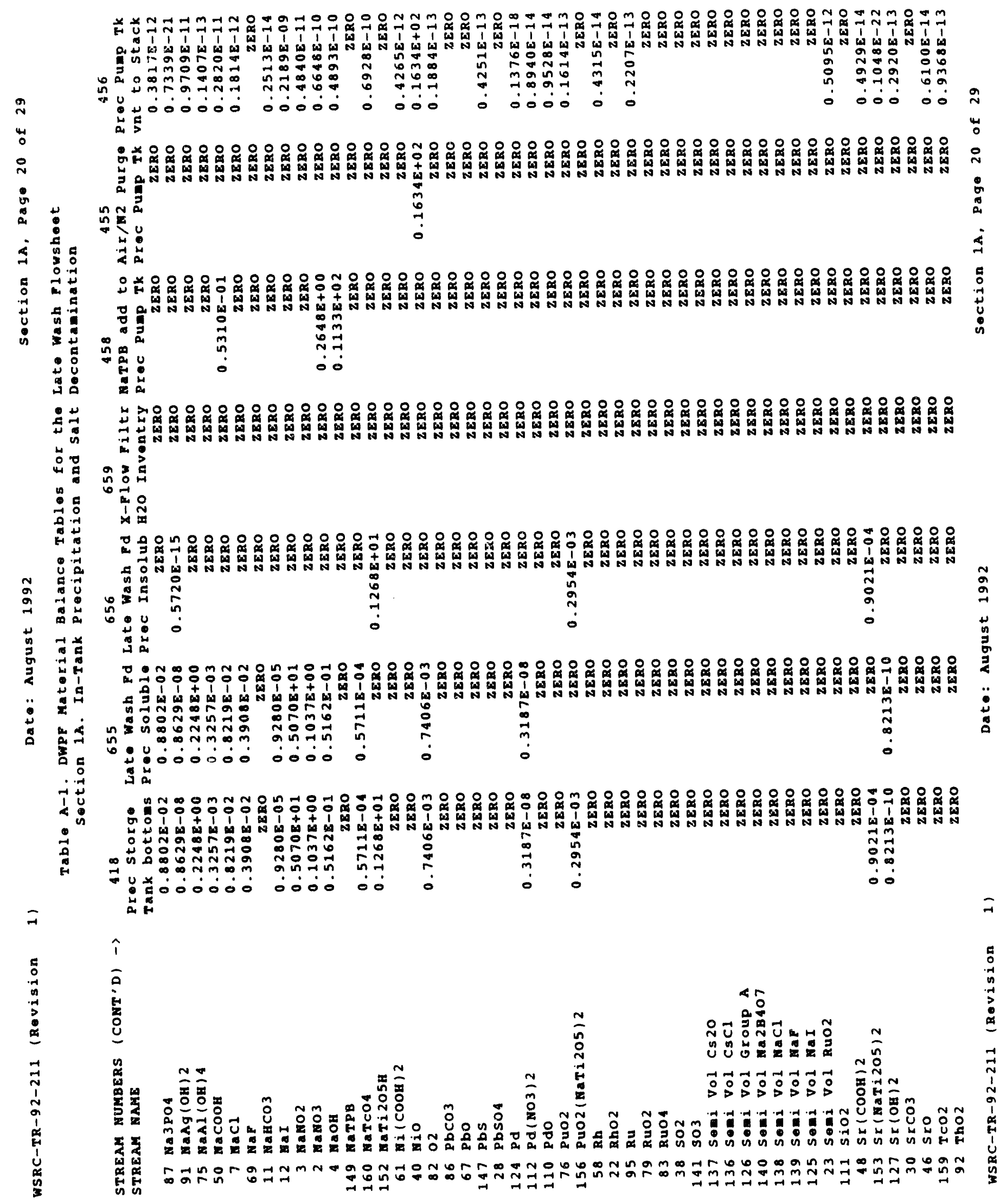




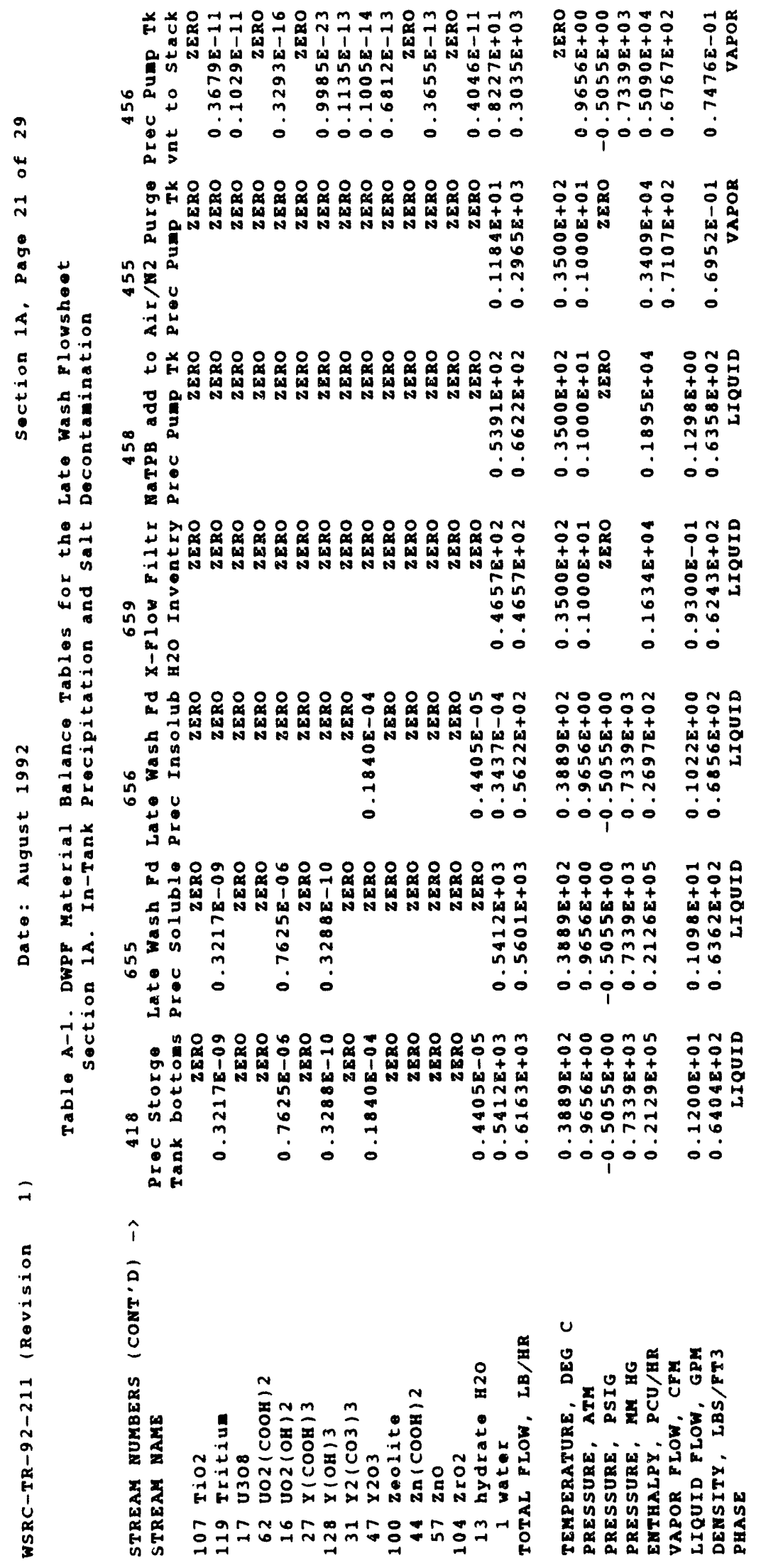

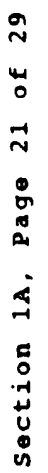




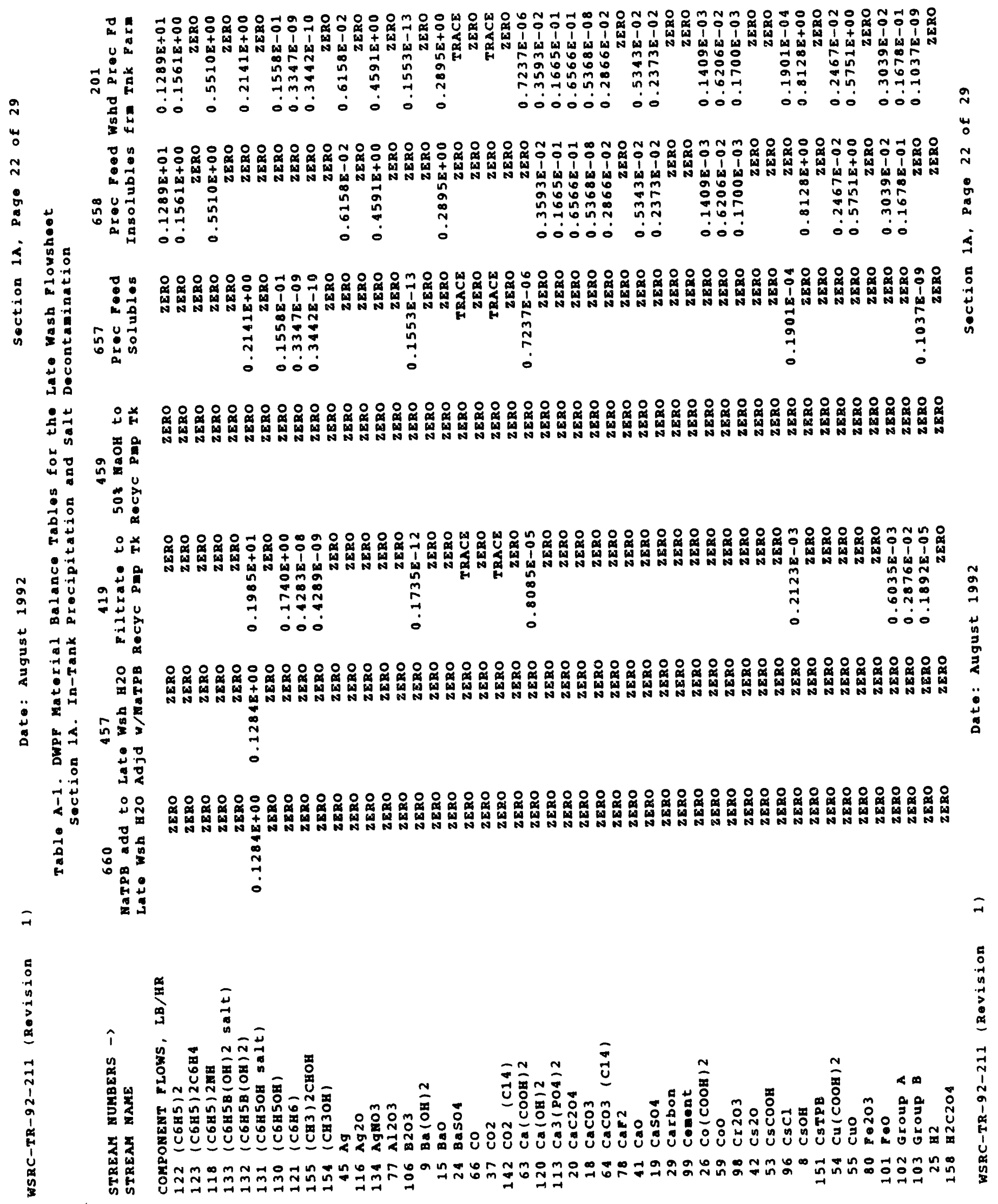




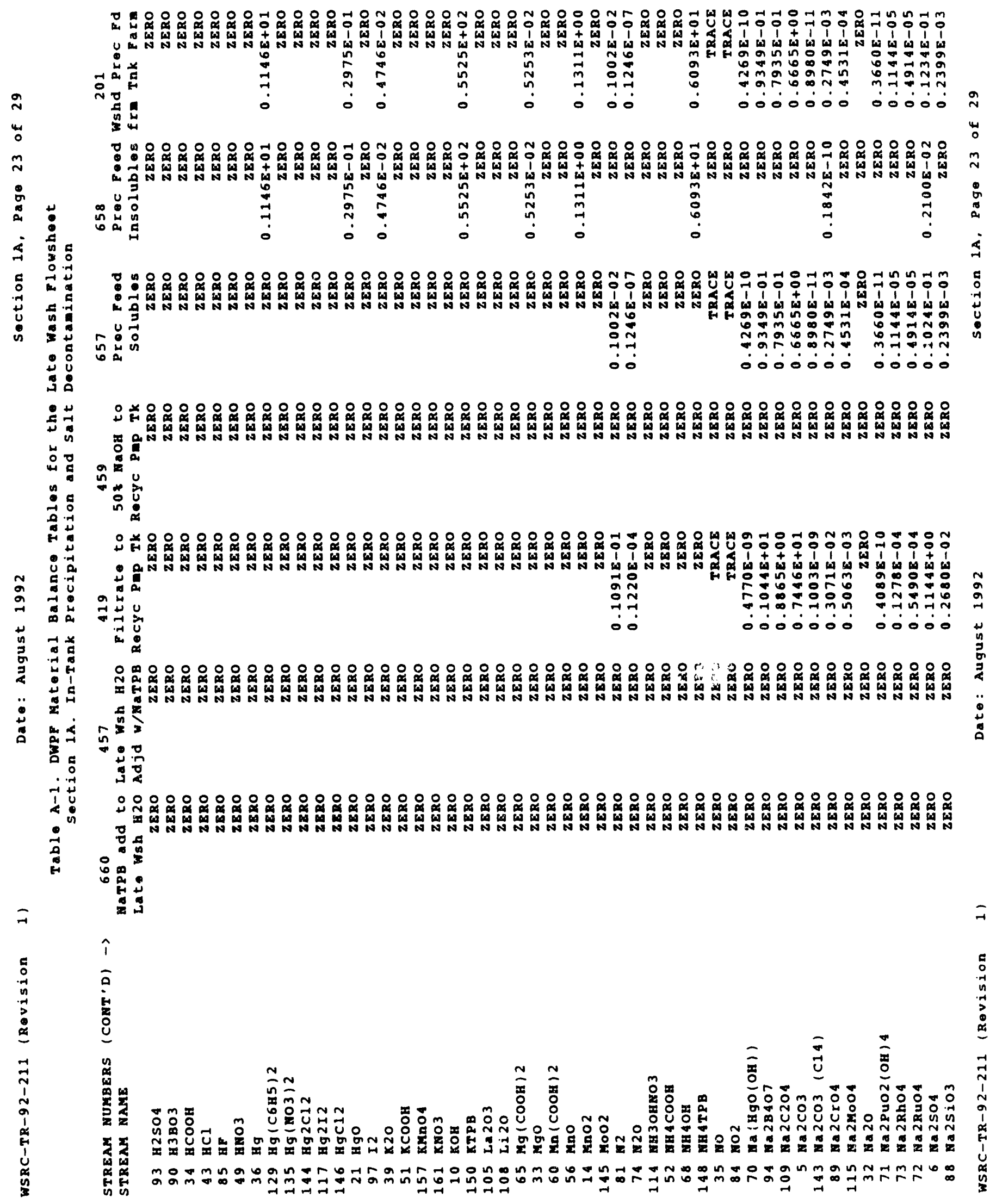




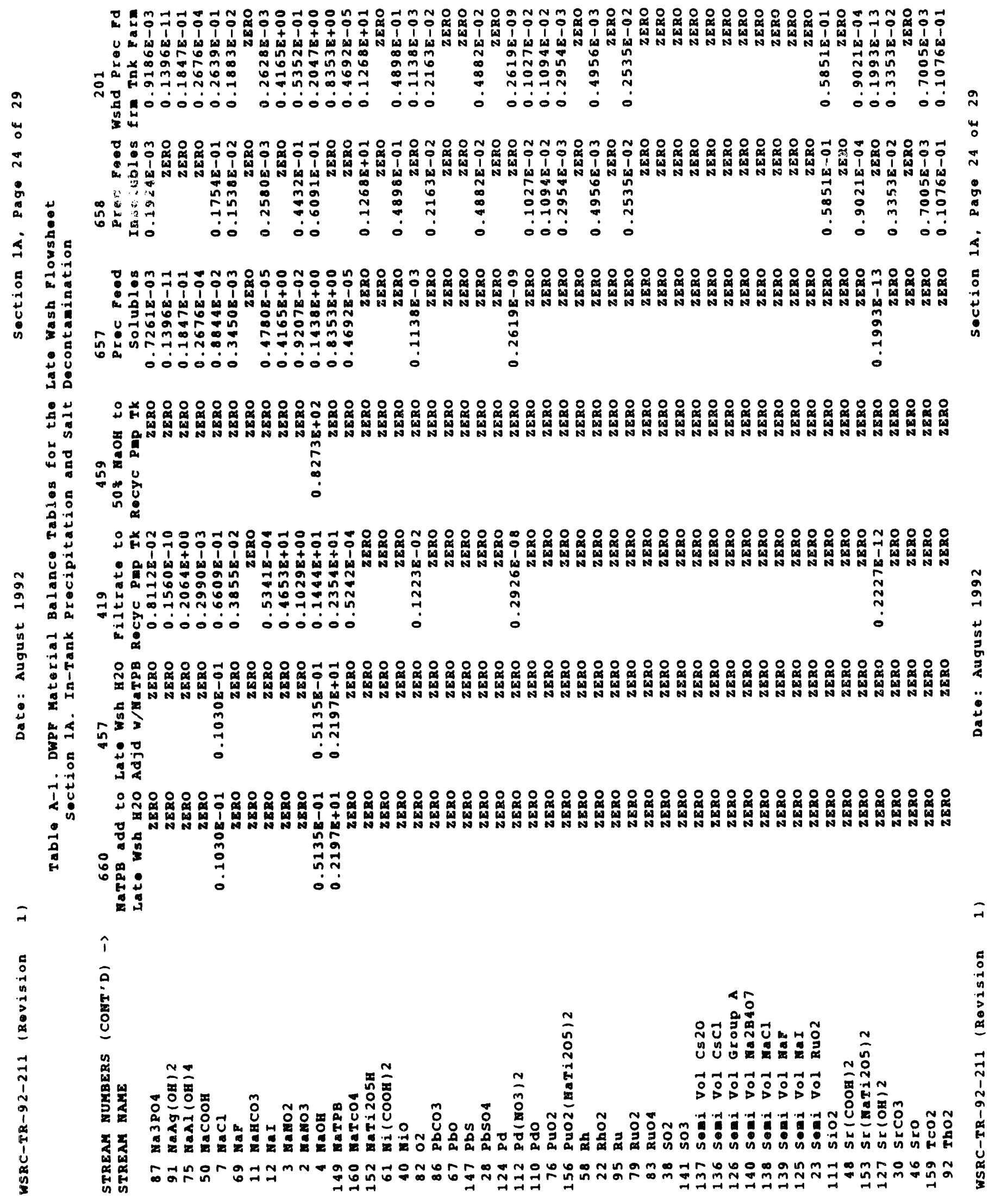




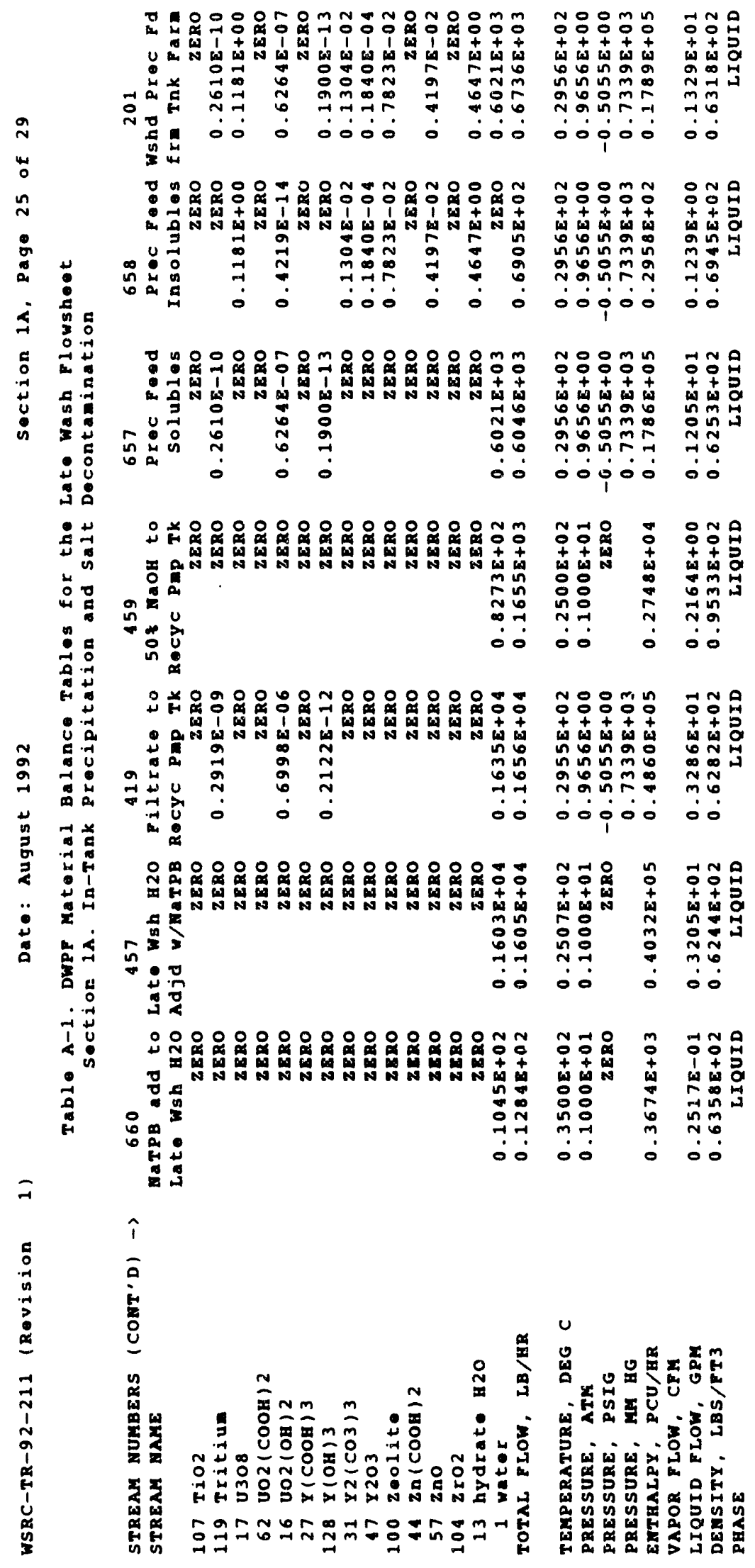




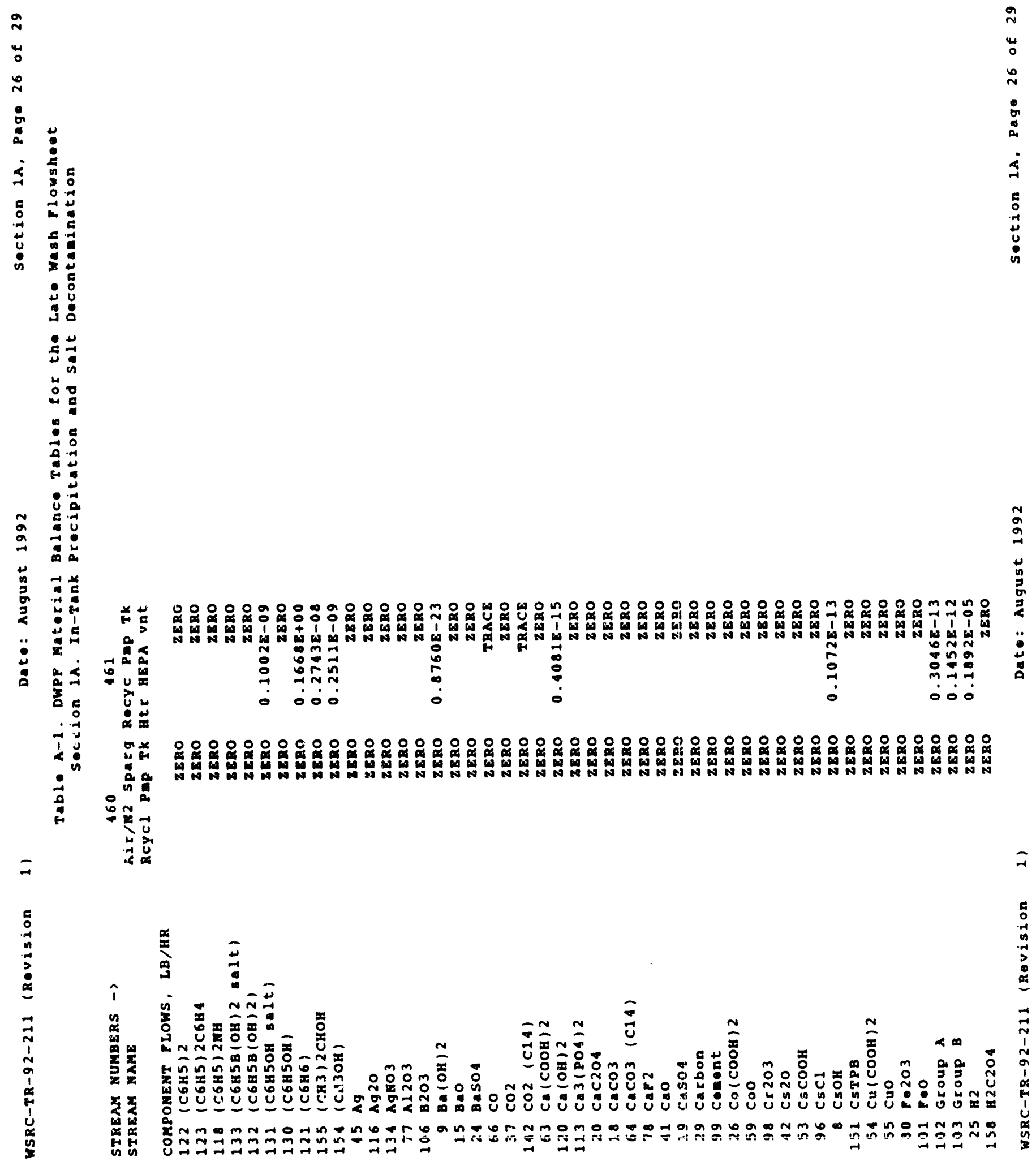




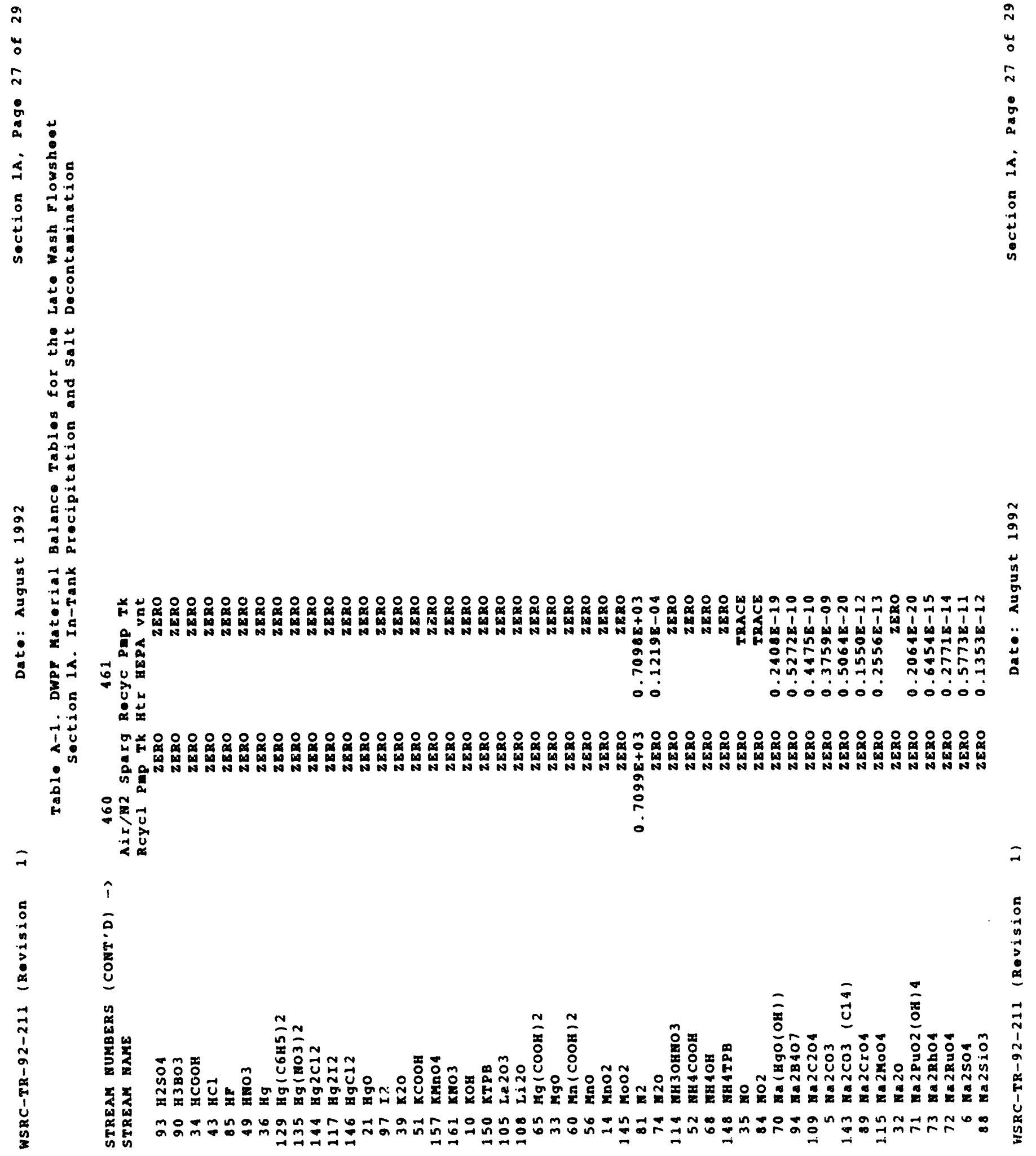




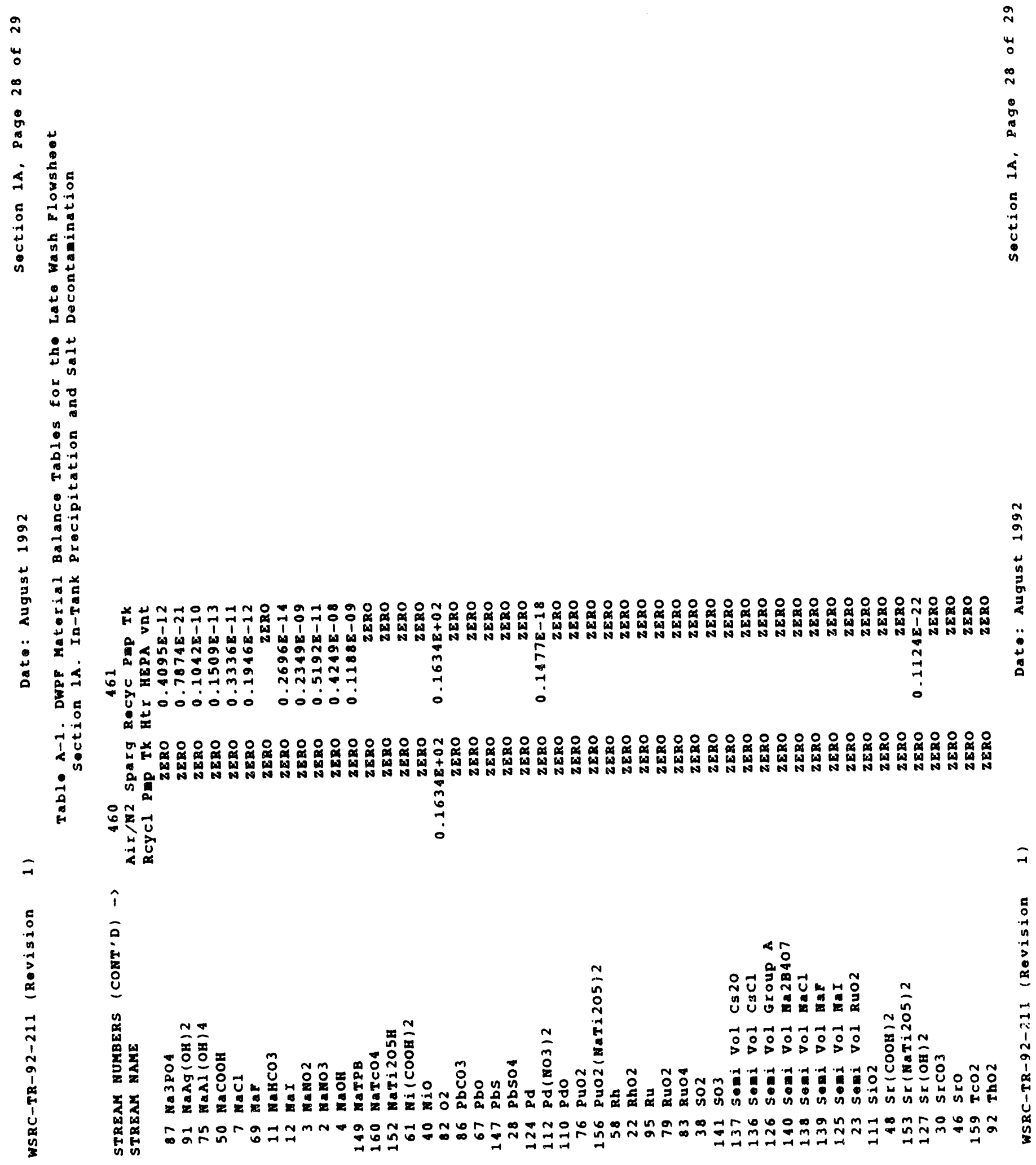




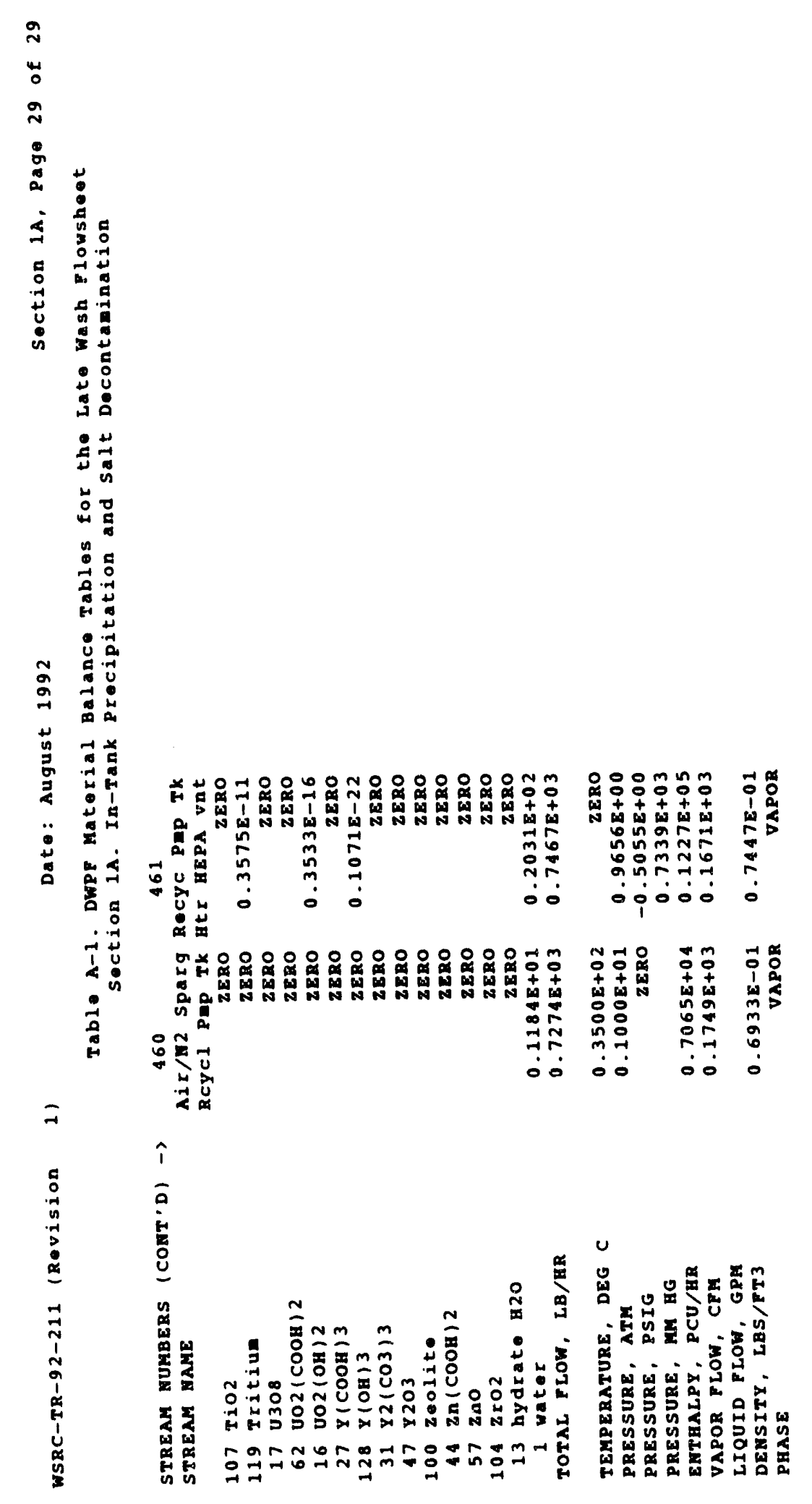


BATCHING ALGORITHMS

\section{GENERAL}

The following algorithms enable determination of all batch additions during a typical Late Wash Cycle based on the analytical results of the last sample of the washed tetraphenylborate precipitate in Tank 49 . A key assumption is ihat no additions are made to Tank 49 without a sample being obtained for analysis following the addition. It is recommended that a sample of the PPT contents be taken after the concentration cycle and analyzed for nitrite concentration in the aqueous fraction of the slurry and the total insolble solids content. Although the washing cycle should be initiated based the calculated wash water requirement (using the appropriate algorithm), the length of the wash cycle allows the wash water requirement tobe confirmed upon receipt of the analytical results and if necessary, the required wash water volume may be adjusted before the end of the wash cycle.

\section{DEFINITIONS}

\section{Parameters}

\begin{tabular}{|c|c|}
\hline $\begin{array}{l}\Delta t \\
\text { SpG } \\
L_{x} \\
M_{x}\end{array}$ & $\begin{array}{l}\text { time elapsed since Tank } 49 \text { analysis, days. } \\
\text { specific gravity at time/location } x \text { (dimensionless) } \\
\text { level in Precipitate Pump Tank at time } x \text {, gal. } \\
\text { mass in Precipitate Pump Tank at time } x \text {, lbs. }\end{array}$ \\
\hline $\begin{array}{l}{\left[\mathrm{K}^{+}\right]_{x}} \\
{\left[\mathrm{NH}_{4}^{+}\right]_{x}}\end{array}$ & $\begin{array}{l}\text { soluble potassium concentration in aqueous fraction at time/location } \mathrm{x}, \mathrm{ppm} \\
\text { soluble ammonium concentration in aqueous fraction at } \\
\text { time/location } \mathrm{x}, \mathrm{ppm}\end{array}$ \\
\hline$\left[\mathrm{Cs}^{+}\right] \mathrm{x}$ & $\begin{array}{l}\text { soluble cesium concentration is aqueous fraction at } \\
\text { time/location } x, \mathrm{ppm}\end{array}$ \\
\hline$\left.\left[\mathrm{NO}_{2}\right]^{-}\right] x$ & $\begin{array}{l}\text { soluble nitrite concentration in aqueous fraction at } \\
\text { time/location } x, \mathrm{ppm}\end{array}$ \\
\hline $\begin{array}{l}{\left[\mathrm{TPB}^{-}\right] \mathrm{x}} \\
{[\mathrm{TIS}]_{\mathrm{x}}}\end{array}$ & $\begin{array}{l}\text { tetraphenylborate concentration in precipitate at time/location } x, w t \% \\
\text { total insoluble solids concentration at time/location } x, w t \%\end{array}$ \\
\hline $\begin{array}{l}{\left[\mathrm{TPB}^{-} \mathrm{Cf}\right]} \\
\text { SPGTPB } \\
\text { FINV }\end{array}$ & $\begin{array}{l}\text { tetraphenylborate concentration in cold feed NaTPB solution, wt\% } \\
\text { specific gravity in cold feed NaTPB solution (dimensionless) } \\
\text { cross-flow fitter layup water inventory, gal. }\end{array}$ \\
\hline $\begin{array}{l}{\left[\mathrm{OH}^{-} \mathrm{cf}\right]} \\
\mathrm{MS}_{x}\end{array}$ & $\begin{array}{l}\text { hydroxide concentration in cold feed caustic tank, M. } \\
\text { mass of insoluble solids in PPT at time/location } x, \text { lbs. }\end{array}$ \\
\hline$M A_{x}$ & mass of aqueous fraction in PPT at time/location $x$, lbs. \\
\hline $\mathrm{MNx}$ & mass of nitrite in PPT at time/location $x$, lbs. \\
\hline MTPBS & $\begin{array}{l}\text { mass of cold feed sodium tetraphenylborate solution } \\
\text { added to the PPT during reprecipitation, Ibs. }\end{array}$ \\
\hline & mass of wash water, lbs. \\
\hline $\begin{array}{l}\text { VWW } \\
\text { LVL } \\
\text { HEEL }\end{array}$ & $\begin{array}{l}\text { volume of wash water, gal. } \\
\text { level in tank (other than PPT), gal. } \\
\text { residual level in tank before a cycle begins, gal. (normally leftover material frol } \\
\text { previous batch) }\end{array}$ \\
\hline
\end{tabular}

\section{Iime/Lecation Designators:}

1

2

3 heel present in the PPT prior to the transfer from Tank 49. contents in PPT after transfer from Tank 49. contents in PPT after Cold Feed NaTPB solution added (i.e. post reprecipitation) 
4 contents in PPT after reconcentration to target of $10 w t \%$ total insoluble solids.

5 contents in PPT post-washing

49 contents in Tank 49 sample

uw wash water

SPT Sludge Pump Tank

RPT Recycle Pump Tank

PPT Precipitate Pump Tank

\title{
Conversion Factors
}

8.345

3.785

319.2

18

39.09

133

337.2

358.3

452.1

$1.0 \times E-06$

from $\mathrm{g} / \mathrm{cm}^{3}$ to $\mathrm{lb} / \mathrm{gal}$

from liters to gallons

formula weight of tetraphenylborate anion, $\mathrm{g} / \mathrm{g}-\mathrm{mol}$

formula weight of ammonium ion, $g / g-m o l$

formula weight of potassium ion, $\mathrm{g} / \mathrm{g} \cdot \mathrm{mol}$

formula weight of (average) cesium ion, $\mathrm{g} / \mathrm{g}-\mathrm{mol}$

formula weight of ammonium tetraphenylborate, $\mathrm{g} / \mathrm{g}-\mathrm{mol}$

formula weight of potassium tetraphenylborate, g/g-mol

formula weight of cesium tetraphenylborate, $g / g-\mathrm{mol}$

from ppm by weight to weight fraction

\section{Abbreviations}

ppm

PPT

SPT

RPT

cf

\author{
parts per million by weight \\ Precipitate Pump Tank \\ Sludge Pump Tank \\ Recycle Pump Tank \\ cold feed
}

\section{ALGORITHM}

\section{Beprecipltation Calculations}

The net addition of cold feed sodium tetraphenylborate solution for reprecipitation is MTPBS where

MTPBS $=$ MTPBS $_{1}+$ MTPBS $_{2}$

MTPBS $_{1}=\left\{\left(L_{2} S_{p} G_{2}-L_{1} S_{p} G_{1}\right) /\left[T^{\prime} B^{-}{ }^{-} f\right]\right\} *\left[0.0015 \Delta t\left[T P B^{-}\right] 49+\left(1-0.01[T I S]_{49}\right) *\left(6.814 E-03\left[K^{+}\right]_{49}+\right.\right.$ $\left.\left.2.00 \mathrm{E}-03\left[\mathrm{Cs}^{+}\right]_{49}+1.48 \mathrm{E}-02\left[\mathrm{NH}_{4}^{+}{ }^{+}\right] 49\right)\right]$

MTPBS $_{2}=\left\{\mathrm{L}_{2}{ }^{-L_{1}}+\mathrm{FINV}+0.1198^{*} \mathrm{MTPBS}_{1} / \mathrm{SPGTPB}^{\circ} \mathrm{c} f\right\} /\left\{0.9386^{*}\left[\mathrm{TPB}^{-}{ }_{\mathrm{cf}}\right]-0.1198 / \mathrm{SpGTPB}^{\circ} \mathrm{cf}\right\}$

These equations are derived as follows:

Calculate mass in PPT prior to transier from Tank 49:

$$
M_{1}=L_{1} S_{p} G_{1}(8.345)
$$

Calculate mass in PPT after transfer from Tank 49:

$$
M_{2}=L_{2} S_{p} G_{2}(8.345)
$$

Net mass transferred from Tank 49 to PPT :

$$
M_{2}-M_{1}=8.345\left(L_{2} S_{p} G_{2}-L_{1} S_{p} G_{1}\right)
$$

Calculate the mass of aqueous fraction transferred into the PPT from Tank 49:

$M A_{49}=\left(M_{2}-M_{1}\right)\left(1-0.01^{*}[T I S]_{49}\right)=8.345\left(L_{2} S_{p} G_{2}-L_{1} S_{p} G_{1}\right)\left(1-0.01^{*}[T I S]_{49}\right)$ 
To calculate MTPBS 1 , the amount of cold feed sodium tetraphenylborate solution to add for re-precipitation, sum two terms, one to precipitate soluble $\mathrm{Cs}^{+}, \mathrm{K}^{+}, \mathrm{NH}_{4}+$ and one to replace tetraphenylborate lost by radiolysis (based on the elapsed time period since the Tank 49 analysis). Then calculate MTPBS 2 to adjust the aqueous fraction to $\geq 0.004 \mathrm{M}$ tetraphenylborate.

To reprecipitate the soluble $\mathrm{Cs}^{+}, \mathrm{K}^{+}, \mathrm{NH}_{4}^{+}$:

$8.345\left(L_{2} S_{p} G_{2}-L_{1} S_{p} G_{1}\right)\left(1-0.01^{*}[T I S]_{49}\right)(1.0 E-06)\left\{\left[K^{+}\right]_{49} / 39.09+\left[\mathrm{Cs}^{+}\right]_{49} / 133+\left[\mathrm{NH}_{4}^{+}\right]_{49} / 18\right\}$

* $\left\{(319.2)(100) /\left[\right.\right.$ TPB $\left.\left.^{-} \mathrm{cf}\right]\right\}$

Mass of NaTPB solution to replace TPB- lost via radiolysis:

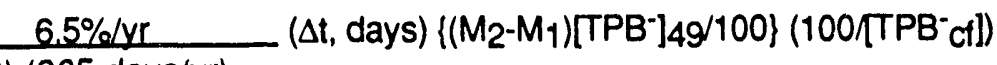

(100) (365 days/yr)

$=0.0015(\Delta t)\left(L_{2} S_{p} G_{2}-L_{1} S_{p} G_{1}\right)^{*}\left[T P^{-}\right] 49 /\left[T P B^{-}{ }_{c t}\right]$

MTPBS $_{1}=\left\{\left(L_{2} S_{p} G_{2}-L_{1} S_{p} G_{1}\right) /\left[\right.\right.$ TPB $\left.\left.^{-}{ }^{-} f\right]\right\} *\left[0.0015 \Delta t\left[T P B B^{*}\right] 49+\left(1-0.01[T I S]_{49}\right) *\left\{6.814 E-03\left[K^{+}\right]_{49}+\right.\right.$ $\left.\left.2.00 \mathrm{E}-03\left[\mathrm{Cs}^{+}\right] 49+1.48 \mathrm{E}-02\left[\mathrm{NH}_{4}{ }^{+}\right] 49\right\}\right]$

Mass of NaTPB solution to obtain excess TPB- at $\geq 0.004 \mathrm{M}^{-1}$ TPB- $^{-}$prior to washing is calculated by rearrangement of the following equation:

$0.004 \mathrm{M}=$ [MTPBS $2_{2}\left(0.01\right.$ TPB $\left.\left.\left.^{-}{ }_{\mathrm{Cf}}\right]\right)(453.59) / 319.2\right\} /\left\{\left(\mathrm{L}_{2}-\mathrm{L}_{1}+\mathrm{FINV}_{+} \mathrm{MTPBS}_{1} / 8.345 / \mathrm{SpG}_{\mathrm{TPB}}{ }^{-} \mathrm{Cf}+\right.\right.$ MTPBS $_{2} / 8.345 /$ SpGTPB $^{*}$ cf $\left.^{*} 3.785\right\}$

The net addition of cold feed sodium tetraphenylborate solution for reprecipitation is then

$M T P B S=M T P B S_{1}+M T P B S_{2}$

Note that $M_{3}=8.345 L_{2} S_{p} G_{2}+M T P B S=8.345 L_{3} S_{p} G_{3}$ can be used to cross-check the addition operation.

$M_{3}=(8.345) L_{3} S_{p} G_{3}$ should be used to calculate net mass in the PPT after reprecipitation.

\section{Calculations for the Reconcentration Step}

The slurry should be concentrated until the product of the level and specfic gravity indicators satisfy the relationship shown below:

$L_{4} S_{p} G_{4}=(0.1) L_{1} S_{p} G_{1}[T I S]_{1}+(0.1)\left(L_{2} S_{p} G_{2}-L_{1} S_{p} G_{1}\right)[T I S]_{49}-F I N{ }^{*} S p G_{4}+\left(L_{2} S_{p} G_{2}-L_{1} S_{p} G_{1}\right)^{*}$ $\left(1-0.01[T I S]_{49}\right)^{*}\left[9.166 \mathrm{E}-05\left[\mathrm{~K}^{+}\right]_{49}+3.40 \mathrm{E}-05\left[\mathrm{C}_{\mathrm{S}}{ }^{+}\right]_{49}+1.87 \mathrm{E}-04\left[\mathrm{NH}_{4}{ }^{+}\right]_{49}\right]$

This equation is derived as follows:

Mass of Insoluble Solids in PPT after reprecipitation:

This quantity can be calculated from the sum of three solids:

1) The mass of insoluble solids in the PPT before the Tank 49 transfer, MS 1.

2) The mass of solids transferred in from Tank $49, M S_{49}$.

3) The mass of insoluble solids generated by reprecipitating the soluble cesium, potassium, and ammonium, $M S_{\text {gen }}$. 
$M S_{3}=M S_{1}+M S_{49}+M S_{g e n}$

where $\quad M S_{1}=L_{1} S_{p} G_{1}(8.345)(0.01)[T I S]_{1}$

$M S_{49}=\left(L_{2} S_{p} G_{2}-L_{1} S_{p} G_{1}\right)(8.345)(0.01)[T I S]_{49}$

$M S_{g e n}=8.345\left(L_{2} S_{p} G_{2}-L_{1} S_{p} G_{1}\right)\left(1-0.01 *[T I S]_{49}\right)(1.0 E-06)^{*}\left\{\left[K^{+}\right]_{49} * 358.3 / 39.09\right.$ $\left.+\left[\mathrm{Cs}^{+}\right]_{49}{ }^{*} 452.1 / 133+\left[\mathrm{NH}_{4}{ }^{+}\right] 49 * 337.2 / 18\right\}$

Note that [TIS $]_{1}$ should normally be the target (10 wt\%) insoluble solids concentration from the previous late wash cycle.

During reconcentration the layup water inventory in the filter will be retumed to the tank. The total mass of fluid in the system is hence $M_{3}+$ FINV*8.345 and this value should be used for the total mass to calculate the total insoluble solids concentration ( $w t \%)$ prior to reconcentration:

$[T I S]_{3}=100^{*} \mathrm{MS}_{3} /\left(\mathrm{M}_{3}+\mathrm{FINV}^{*} 8.345\right)$

The target solids is [TIS] 4 , assumed to be10 wt\%. All of the solids present after reprecipitation are assumed 10 be retained in the PPT and the filter, but the mass of aqueous fraction will change. The total mass of fluid in the system at the start of the reconcentration will be $\mathrm{M}_{4}+\mathrm{FINV}^{*} 8.345^{*} \mathrm{SpG}_{4}$ and this value should be included in the total mass to calculate the endpoint for econcentration:

$0.1=M S_{3} /\left(M_{4}+F I N{ }^{*} 8.345^{*} S_{p G}\right)=M S_{3} /\left(8.345^{*} S_{p} G_{4}\left(L_{4}+F I N V\right)\right\}$ or $8.345 S_{p} G_{4}\left(L_{4}+F I N V\right)=10 M_{3}$

Substituting the terms for $\mathrm{MS}_{3}$ derived previously,

$L_{4} S_{p} G_{4}=1.198\left[\left(L_{1} S_{p} G_{1}(8.345)(0.01)\left[T / S_{1}\right)+\left(\left(L_{2} S_{p} G_{2}-L_{1} S_{p} G_{1}\right)(8.345)(0.01)[T I S]_{49}\right)\right.\right.$

$+8.345\left(L_{2} S_{p} G_{2}-L_{1} S_{p} G_{1}\right)\left(1-0.01[T / S]_{49}\right)(1.0 E-06)\left\{\left[K^{+}\right] 49 * 358.3 / 39.09+\left[C_{s}{ }^{+}\right]_{49}{ }^{*} 452.1 / 133+\right.$

Simplifying terms, $\left[\mathrm{NH}_{4}{ }^{+}\right]_{49}$ "337.2/18)] - (FINV*SpG 4$)$

$L_{4} S_{p} G_{4}=(0.1) L_{1} S_{p} G_{1}[T I S]_{1}+(0.1)\left(L_{2} S_{p} G_{2}-L_{1} S_{p} G_{1}\right)[T I S]_{49}-F I N{ }^{*} S_{p G} G_{4}+\left(L_{2} S_{p} G_{2}-L_{1} S_{p} G_{1}\right)^{*}$ $(1-0.01[\mathrm{TIS}] 49)^{*}\left[9.166 \mathrm{E}-05\left[\mathrm{~K}^{+}\right]_{49}+3.40 \mathrm{E}-05\left[\mathrm{C}_{\mathrm{S}}{ }^{+}\right]_{49}+1.87 \mathrm{E}-04\left[\mathrm{NH}_{4}{ }^{+}\right]_{49}\right]$

\section{Washing Crcle}

Calculate the initial nitrite concentration:

Mass of nitrite in PPT prior to transfer from Tank 49 (in lbs):

$M N_{1}=8.345\left(L_{1} S_{p} G_{1}\right)\left(1-0.01[T I S]_{1}\right)(1.0 E-06)\left[N_{2}{ }^{-}\right] 1$

Mass of nitrite transferred into PPT from Tank 49, Ibs:

$M N_{49}=8.345\left(L_{2} S_{p} G_{2}-L_{1} S_{p} G_{1}\right)\left(1-0.01[T I S]_{49}\right)(1.0 E-06)\left[N_{2}{ }^{-}\right] 49$

Mass of supernate after reprecipitation, Ibs:

$M A_{3}=8.345\left(\left(F I N V+L_{3} S_{p} G_{3}\right)\left(1-0.01[T I S]_{3}\right)\right)$

Nitrite concentration after reprecipitation, (identical to the initial nitrite concentration for the washing step, is calculated as follows:

$C_{i}=1.0 E+06^{*}\left(M N_{1}+M N_{49}\right) / M A_{3}$ or 
$C_{i}=1.0 E+06^{*}\left\{\left[8.345\left(L_{1} S_{p} G_{1}\right)\left(1-0.01[T I S]_{1}\right)(1.0 E-06)\left[N O_{2}\right]_{1}+8.345\left(L_{2} S_{p} G_{2}-L_{1} S_{p} G_{1}\right)^{*}\right.\right.$

Simplifying terms,

$\left.C_{i}=\left\{L_{1} S_{p} G_{1}\left(1-0.01[T I S]_{1}\right)\left[N O_{2}^{-}\right]_{1}+\left(L_{2} S_{p} G_{2}-L_{1} S_{p} G_{1}\right)\left(1-0.01[T I S]_{49}\right)\left[N O_{2}{ }^{-}\right] 49\right]\right\} /\left[F I N V+L_{3} S_{p} G_{3}{ }^{*}\right.$

$C_{f}=0.01 \mathrm{M}$, or converting to ppm:

$C_{f}=.01 \mathrm{~g}$-mole/liter * $46 \mathrm{~g} / \mathrm{g}$-mole * [1 liter $\left./\left(1000 * \mathrm{SpG}_{5}\right)\right] * 1.0 \mathrm{E}+06=460 / \mathrm{SpG}_{5} \mathrm{ppm}$.

Note: The value of $\mathrm{SpG}_{5}$ from the previous batch may be used to estimate the new final specific gravity.

Calculate mass of aqueous fraction after reconcentration step:

$\mathrm{MA}_{4}=8.345 \mathrm{~L}_{4} \mathrm{~S}_{\mathrm{p}} \mathrm{G}_{4}\left(1-0.01[\mathrm{TIS}]_{4}\right)$

Mass of wash to add $=(M w w)=M A_{4}{ }^{*} \ln \left(C_{j} / C_{t}\right)$ thus

$M w w=8.345 L_{4} S_{p} G_{4}\left(1-0.01[T I S]_{4}\right){ }^{*} \ln (\mathrm{Ci} / \mathrm{Cf})$

Where $C_{i}$ and $C_{f}$ are as shown previously.

Volume of wash water $=\mathrm{Vww}$

$V w w=M w w /\left\{8.345\left(S p G_{w w}\right)\right\}$

\section{Salculations for the Spent Wash Water Inhlbitor Adjustment to $>1.0 \mathrm{M} \mathrm{OH}$}

Target $=1.2 \mathrm{M} \mathrm{OH}$.

Materia: is $50 w+\% ~ N a O H$ aqueous solution, for which the analysis is in $\mathrm{M}$.

RPTLVL, SPTLVL represent the spent wash water levels in the RPT and SPT, respectively.

Calculate volume in liters: $3.785^{*}$ RPTLVL or $3.785^{*}$ SPTLVL

Assume that $y$ gallons of the caustic solution are added to the SPT. Then, accounting for the heel (which should already be adjusted to $\geq 1.0 \mathrm{M}$ hydroxide) the volume to adjust in liters is given by

$V=3.785^{\star}(y+S P T L V L-S P T H E E L)$.

The caustic added (g-moles) is $3.785^{*} \mathrm{y}^{*}\left[\mathrm{OH}^{-} \mathrm{cf}\right]$. Then to achieve $1.2 \mathrm{M} \mathrm{OH}$ - we desire that

$3.785^{*} y^{*}\left[\mathrm{OH}^{-} \mathrm{cf}\right] /\left\{3.785^{*}(y+\right.$ SPTLVL-SPTHEEL $\left.)\right\}=1.2$ or, solving for $y$,

$y=1.2^{*}\left(\right.$ SPTLVL-SPTHEEL) $/\left\{\left[\mathrm{OH}^{-} \mathrm{Cf}\right]-1.2\right\}$ or

$y=($ SPTLVL-SPTHEEL $) /\left\{\left(\left[\mathrm{OH}^{-} \mathrm{Ct}\right] / 1.2\right)-1.2\right\}$

The adjustment of the RPT is analogous.

\section{Surfactant Addition}

(post concentration step)

Mass in PPT $=8.345 \mathrm{SpG}_{4} \mathrm{~L}_{4}$

Mass Active ingredient to achieve $500 \mathrm{ppm}=(500)(1.0 \mathrm{E}-06) 8.345\left[\mathrm{SpG}_{4} \mathrm{~L}_{4}+\mathrm{FINV}\right]$ 
Mass Surfactant Solution $=\frac{100 \mathrm{lb} \text { solution }}{50 \mathrm{~b} \text { active ingredient }} *(500)(1.0 \mathrm{E}-06)(8.345)\left[\mathrm{S}_{\mathrm{p}} \mathrm{G}_{4} \mathrm{~L} 4+\mathrm{FINV}\right]$

$=(8.345 \mathrm{E}-03)\left[\mathrm{L}_{4} \mathrm{~S}_{\mathrm{p}} \mathrm{G}_{4}+\mathrm{FINV}\right]$

Note: If the surfactant is to be added after the reprecipitation step, the equation becomes

(8.345E-03) [L3SpG + FINV]

NaTPB Adiustment of Wash Water

Target is $0.004 \mathrm{M} \mathrm{TPB}^{-}$

Add the following volumetric ratio of gallons of cold feed tetraphenylborate solution per gallon of wash water to achieve $0.004 \mathrm{M}$ TPB:

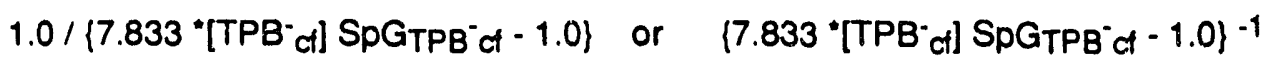



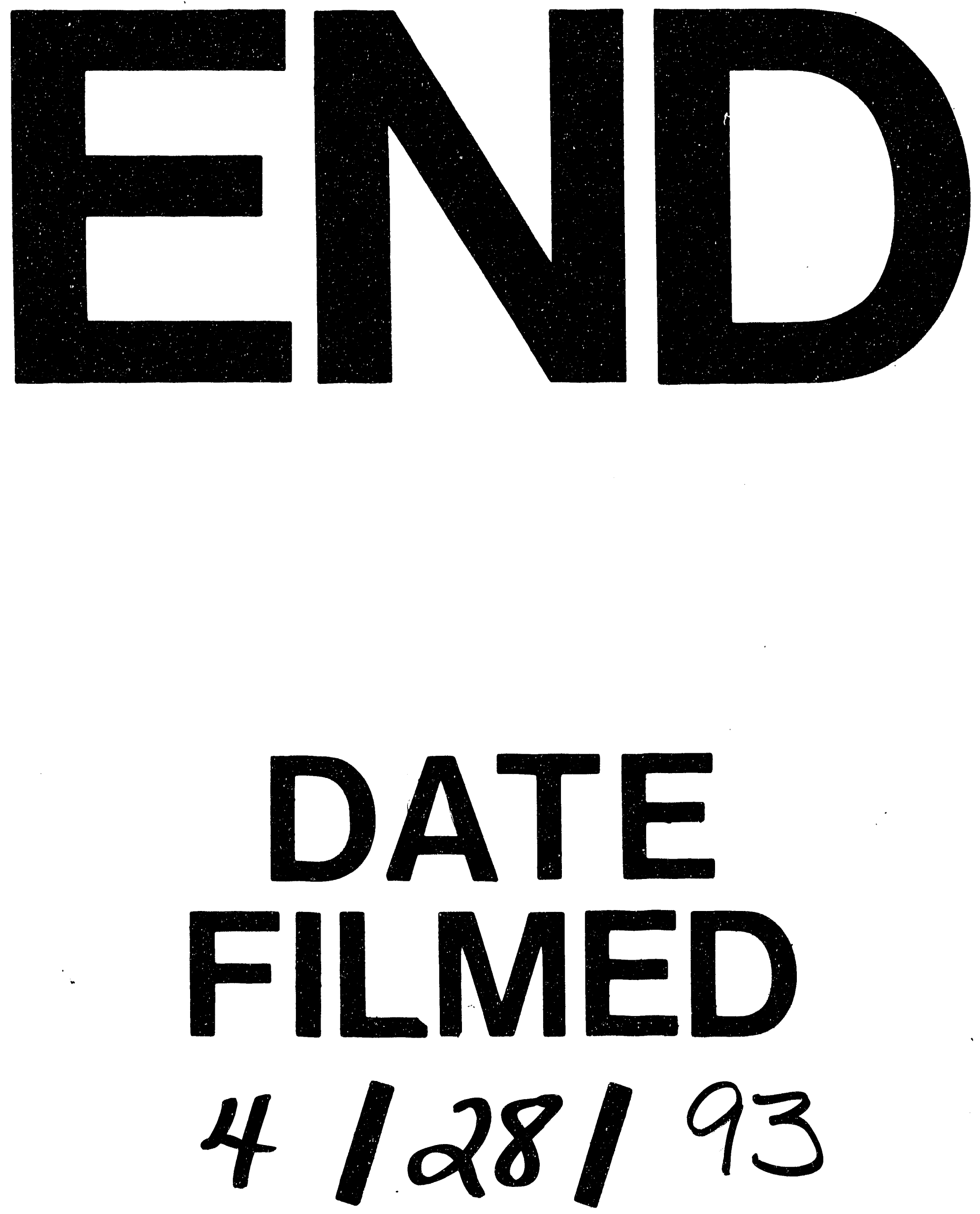

I 
